\title{
Idaho National Laboratory's FY12 Greenhouse Gas Report
}

\author{
Kimberly Frerichs
}

March 2013

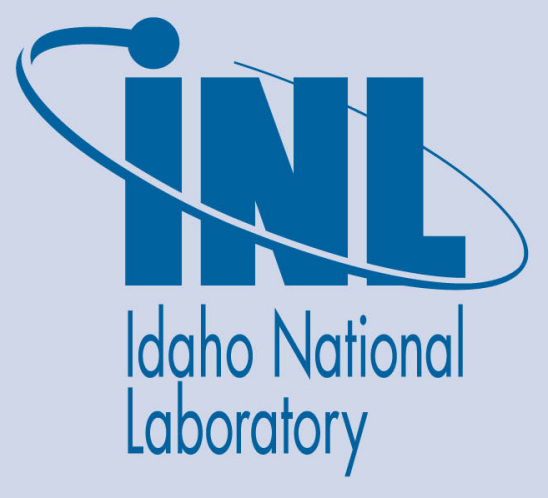

The INL is a U.S. Department of Energy National Laboratory operated by Battelle Energy Alliance 


\section{DISCLAIMER}

This information was prepared as an account of work sponsored by an agency of the U.S. Government. Neither the U.S. Government nor any agency thereof, nor any of their employees, makes any warranty, expressed or implied, or assumes any legal liability or responsibility for the accuracy, completeness, or usefulness, of any information, apparatus, product, or process disclosed, or represents that its use would not infringe privately owned rights. References herein to any specific commercial product, process, or service by trade name, trade mark, manufacturer, or otherwise, does not necessarily constitute or imply its endorsement, recommendation, or favoring by the U.S. Government or any agency thereof. The views and opinions of authors expressed herein do not necessarily state or reflect those of the U.S. Government or any agency thereof. 


\title{
Idaho National Laboratory's FY12 Greenhouse Gas Report
}

\author{
Kimberly Frerichs
}

March 2013

Idaho National Laboratory Idaho Falls, Idaho 83415

\author{
http://www.inl.gov
}

Prepared for the

U.S. Department of Energy

Office of Nuclear Energy

Under DOE Idaho Operations Office

Contract DE-AC07-05ID14517 



\section{EXECUTIVE SUMMARY}

A greenhouse gas (GHG) inventory is a systematic approach to account for the production and release of certain gases generated by an institution from various emission sources. The gases of interest are those that climate science has identified as related to anthropogenic global climate change. This document presents an inventory of GHGs generated during Fiscal Year (FY) 2012 by Idaho National Laboratory (INL), a Department of Energy (DOE)-sponsored entity, located in southeastern Idaho.

In recent years, concern has grown about the environmental impact of GHGs. This, together with a desire to decrease harmful environmental impacts, would be enough to encourage the calculation of an inventory of the total GHGs generated at INL. Additionally, INL has a desire to see how its emissions compare with similar institutions, including other DOE national laboratories. Executive Order 13514 requires that federal agencies and institutions document reductions in GHG emissions.

INL's GHG inventory was calculated according to methodologies identified in federal GHG guidance documents using operational control boundaries. It measures emissions generated in three scopes: (1) INL emissions produced directly by stationary or mobile combustion and by fugitive emissions, (2) the share of emissions generated by entities from which INL purchased electrical power, and (3) indirect or shared emissions generated by outsourced activities that benefit INL (occur outside INL's organizational boundaries, but are a consequence of INL's activities).

This inventory found that INL generated $78,965 \mathrm{MT}_{\text {of }} \mathrm{CO}_{2}$-equivalent emissions during FY12. The following conclusions were made from looking at the results of the individual contributors to INL's FY12 GHG inventory:

- Electricity (including the associated transmission and distribution losses) is the largest contributor to INL's GHG inventory, with over $50 \%$ of the $\mathrm{CO}_{2} \mathrm{e}$ emissions

- Other sources with high emissions were employee commuting, mobile combustion (fleet fuels), stationary combustion (facility fuels), business air travel, and waste disposal (including fugitive emissions from the onsite landfill and contracted disposal)

- Sources with low emissions were wastewater treatment (onsite and contracted), business ground travel (in personal and rental vehicles), and fugitive emissions from refrigerants.

This report details the methods behind quantifying INL's GHG inventory and discusses lessons learned on better practices by which information important to tracking GHGs can be tracked and recorded. It is important to note that because this report differentiates between those portions of INL that are managed and operated by Battelle Energy Alliance (BEA) and those managed by other contractors, it includes only that large proportion of Laboratory activities overseen by BEA. It is assumed that other contractors will provide similar reporting for those activities they manage, where appropriate. 


\section{ACKNOWLEDGMENTS}

The author would like to extend recognition to the following individuals for their thoughtful review of this document and/or calculations:

- Ernest Fossum, Sustainable INL Energy Manager

- Chris Ischay, Sustainable INL Program Manager

- Heather Rohrbaugh, INL Editor. 


\section{CONTENTS}

EXECUTIVE SUMMARY

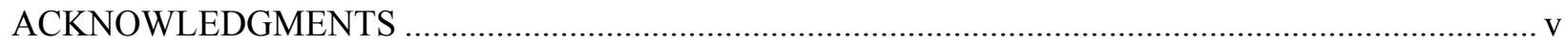

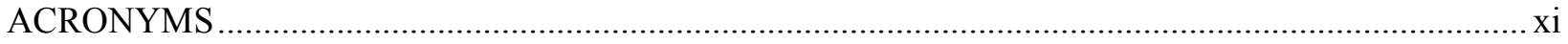

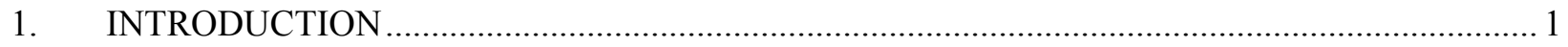

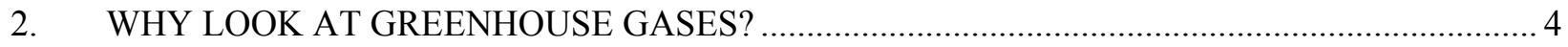

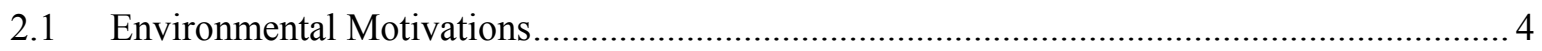

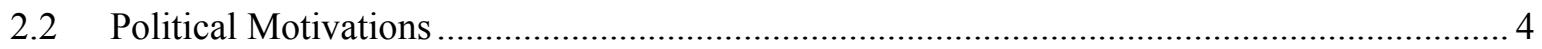

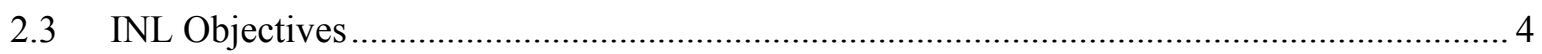

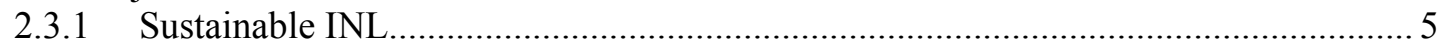

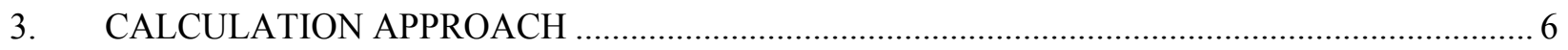

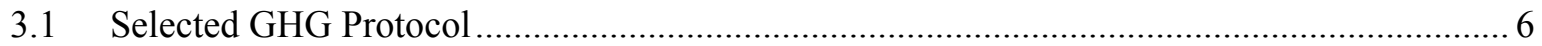

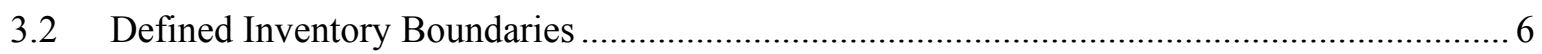

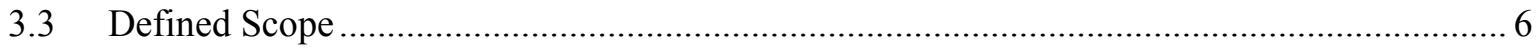

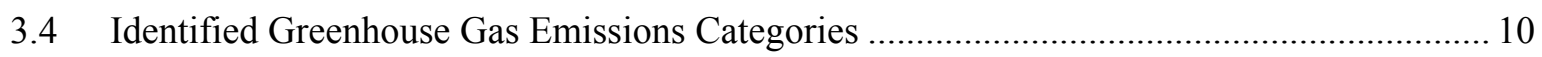

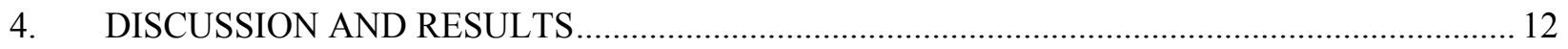

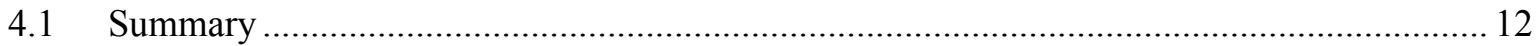

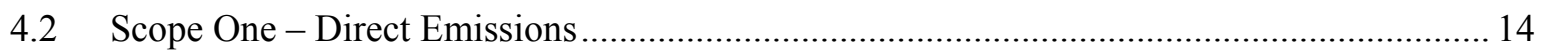

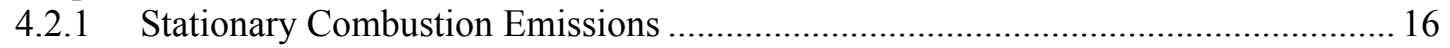

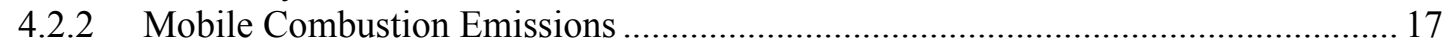

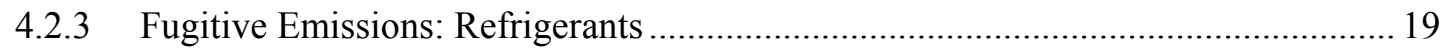

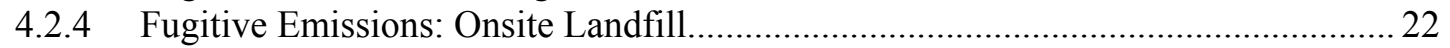

4.2.5 Fugitive Emissions: Onsite Wastewater Treatment ............................................... 24

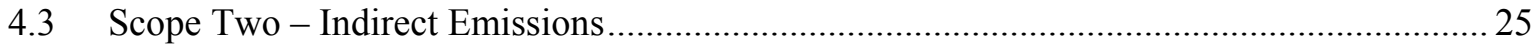

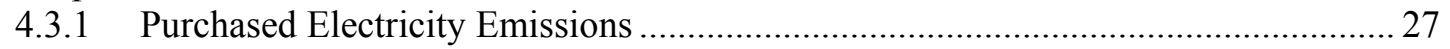

4.3.2 Transmission and Distribution Loss Emissions, Owned........................................ 28

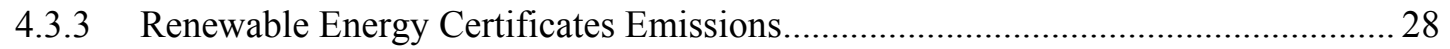

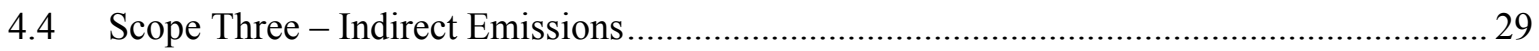

4.4.1 Transmission and Distribution Loss Emissions, Shared ........................................ 31

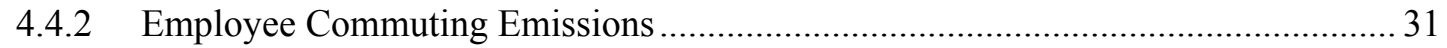

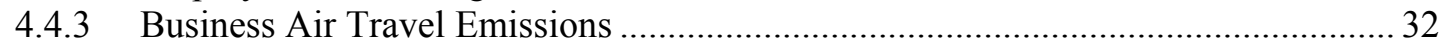

4.4.4 Business Ground Travel: Rental Vehicle Emissions …........................................... 34

4.4.5 Business Ground Travel: Personal Vehicle Emissions ............................................. 34

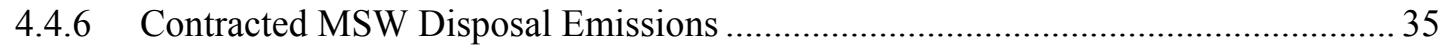

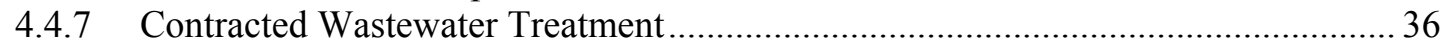

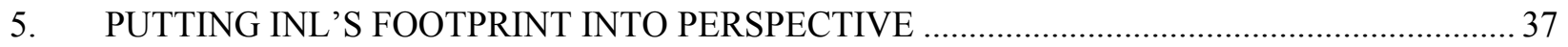

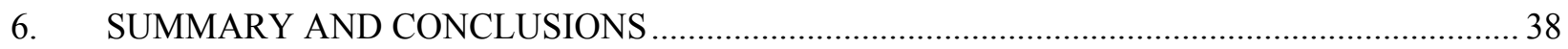

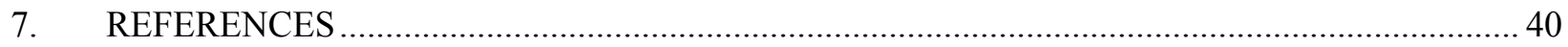




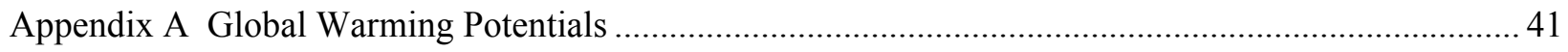

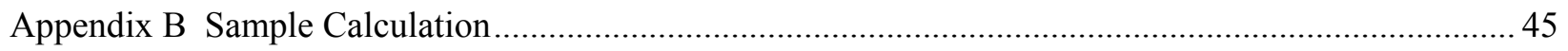

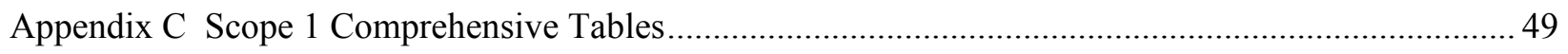

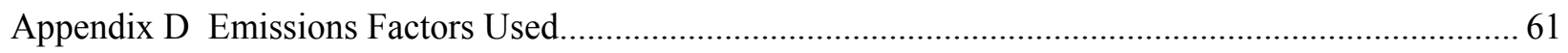

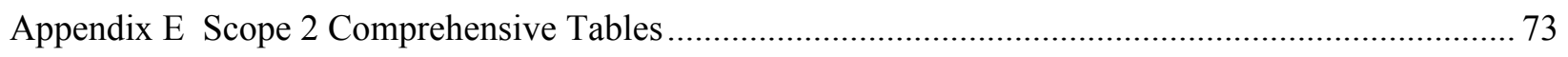

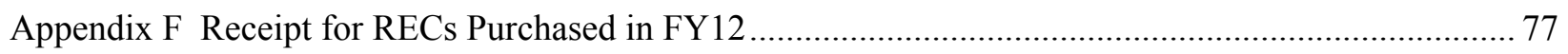

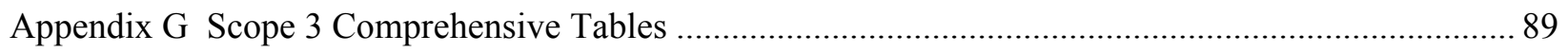

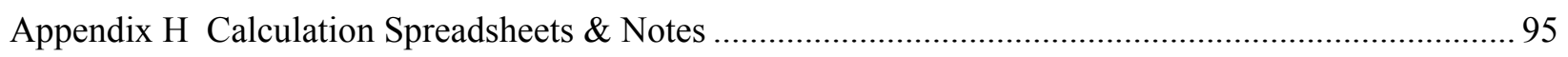

\section{FIGURES}

Figure 1. Location map of the INL Site and major facilities. .......................................................... 2

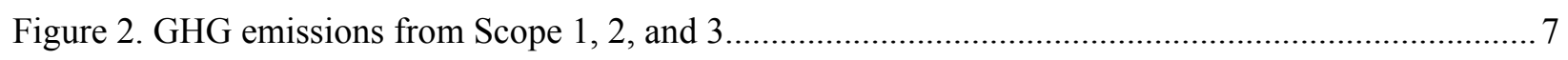

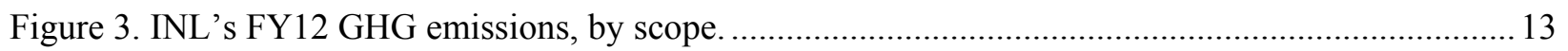

Figure 4. INL's FY12 GHG emissions, by scope and emissions category, excluding biogenic

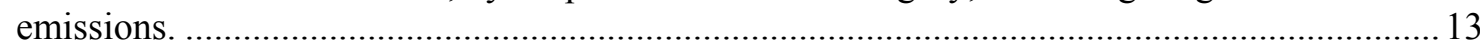

Figure 5. Comparison of INL's FY08, FY09, FY10, FY11, and FY12 GHG emissions, by scope

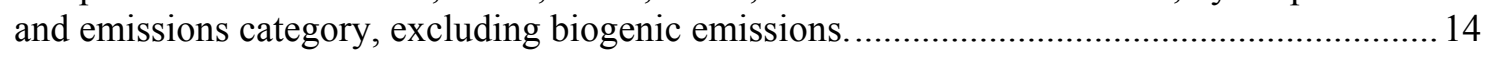

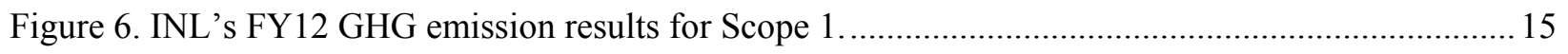

Figure 7. Comparison of INL's FY08, FY09, FY10, FY11, and FY12 Scope 1 GHG emissions.............. 15

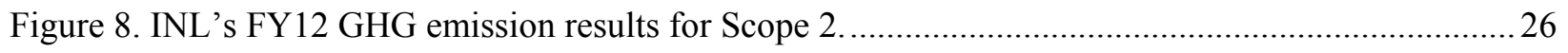

Figure 9. Comparison of INL's FY08, FY09, FY10, and FY12 Scope 2 GHG emissions....................... 26

Figure 10. INL's FY12 GHG emission results for Scope 3 .............................................................. 30

Figure 11. Comparison of INL's FY08, FY09, FY10, FY11, and FY12 Scope 3 GHG emissions............ 30

Figure 12. Comparison of INL's FY08, FY09, FY10, FY11, and FY12 actual, and FY20 goal

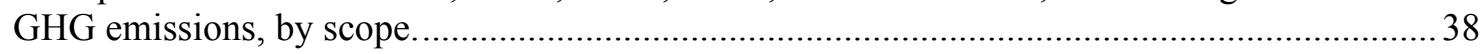




\section{TABLES}

Table 1. GHG emissions categories identified in Guidance and TSD . ..................................................... 8

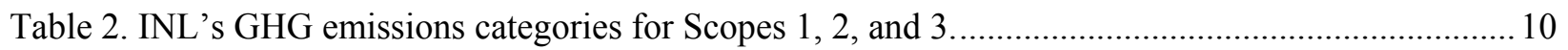

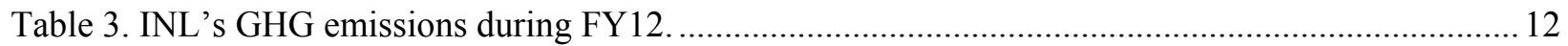

Table 4. Amounts of fuel used for stationary combustion at INL during FY12 ..................................... 16

Table 5. Fuel amounts and corresponding GHG emissions for INL's FY12 fleet.................................. 18

Table 6. Fugitive refrigerants evaluated for GHG emissions during FY12 at INL. ..............................20

Table 7. Amount of solid waste produced annually since 1984 for disposal in INL's onsite CFA

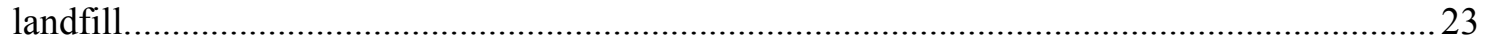

Table 8. FY12 population data by facility for onsite wastewater treatment calculations........................25

Table 9. INL's FY12 electrical purchases by location and provider. .....................................................2 27

Table 10. INL's GHG emissions from electricity and RECs purchased in FY12 ................................29

Table 11. Number and type of commute miles traveled by INL employees during FY12 ...................... 32

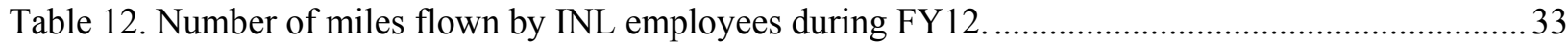

Table 13. Number of vehicle-miles traveled in rental cars by INL employees during FY12.................... 34

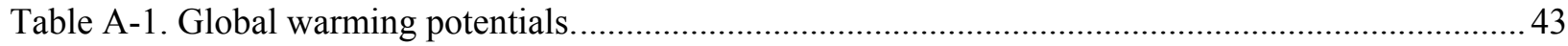

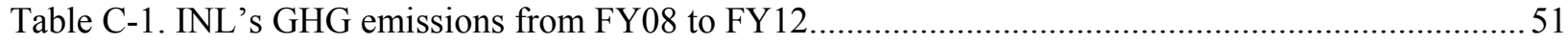

Table C-2. Amounts of fuel used for stationary combustion at INL during FY08 ..................................52

Table C-3. Amounts of fuel used for stationary combustion at INL during FY09.................................52

Table C-4. Amounts of fuel used for stationary combustion at INL during FY10 ..................................52

Table C-5. Amounts of fuel used for stationary combustion at INL during FY11 .................................52

Table C-6. Amounts of fuel used for stationary combustion at INL during FY12 .................................53

Table C-7. Fuel amounts and corresponding GHG emissions for INL's FY08 fleet................................54

Table C-8. Fuel amounts and corresponding GHG emissions for INL's fleet—FY09 to FY11 ..............56

Table C-9. Fuel amounts and corresponding GHG emissions for INL's FY12 fleet.............................58

Table C-10. Fugitive refrigerants evaluated for GHG emissions from FY08 to FY12 at INL.................59

Table D-1. Stationary combustion conversion and emissions factors used. ............................................ 63

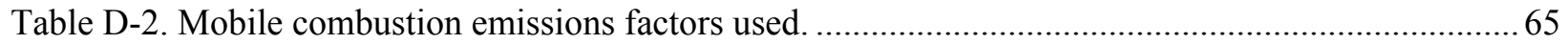

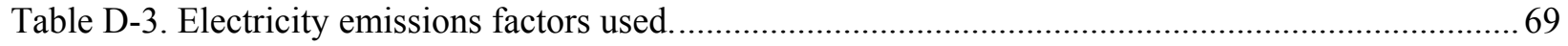

Table D-4. Employee commute, rental car miles, and personal car miles emissions factors used.............70

Table D-5. Business travel airline miles emissions factors used. ......................................................... 71

Table E-1. INL's GHG emissions from electricity and RECs purchased in FY08-FY12 _....................... 75

Table G-1. Number and type of commute miles traveled by INL employees during FY08 to

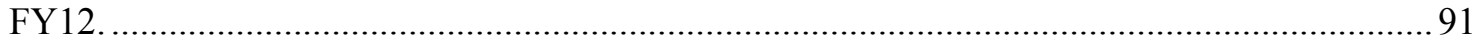

Table G-2. Number of miles flown by INL employees during FY08 ................................................. 93 
Table G-3. Number of miles flown by INL employees during FY09 - FY12.

Table G-4. Number of vehicle-miles traveled in rental cars by INL employees during FY08 FY12.......

Table H-1. Calculation Spreadsheets and Comments for Emissions Categories included in the INL FY12 GHG Inventory. 


\section{ACRONYMS}

AMWTP Advanced Mixed Waste Treatment Project

ATR Advanced Test Reactor

BEA Battelle Energy Alliance

CAS Chemical Abstract Service

CEDR Consolidated Energy Data Report

CFA Central Facilities Area

CITRC Critical Infrastructure Test Range Complex

CNG Compressed Natural Gas

$\mathrm{CO}_{2} \quad$ carbon dioxide

$\mathrm{CO}_{2} \mathrm{e} \quad \mathrm{CO}_{2}$ equivalents

CWI CH2M-WG Idaho, LLC

DOE Department of Energy

DOE-HQ Department of Energy Headquarters

DOE-ID Department of Energy Idaho Operations Office

eGRID Emissions \& Generation Resource Integrated Database

EIA Energy Information Administration

EO executive order

EPA Environmental Protection Agency

FERC Federal Energy Regulatory Commission

FY fiscal year

GHG greenhouse gas

GSA General Services Administration

GWP Global Warming Potential

HHV higher heating value

ICP Idaho Cleanup Project

INEEL Idaho National Engineering and Environmental Laboratory (a forerunner of INL)

INL Idaho National Laboratory

INTEC Idaho Nuclear Technology Center

INWMIS INEEL Nonradiological Waste Management Information System

ITG Idaho Treatment Group

IWTS Integrated Waste Tracking System

LandGEM Landfill Gas Emissions Model

LMI Land Management Institute 


$\begin{array}{ll}\text { LNG } & \text { Liquefied Natural Gas } \\ \text { LPG } & \text { Liquefied Propane Gas } \\ \text { MFC } & \text { Materials and Fuels Complex } \\ \text { MRR } & \text { Mandatory Reporting of Greenhouse Gases Rule } \\ \text { MSW } & \text { municipal solid waste } \\ \text { MT } & \text { metric tonnes } \\ \text { NRF } & \text { Naval Reactors Facility } \\ \text { NWPP } & \text { Northwest Power Pool } \\ \text { PSS } & \text { Public Sector Standard } \\ \text { REC } & \text { Renewable Energy Certificate } \\ \text { SMC } & \text { Specific Manufacturing Capability } \\ \text { T\&D } & \text { Transmission \& Distribution } \\ \text { TIMS } & \text { Transportation Issues Management System } \\ \text { TSD } & \text { Technical Support Document } \\ \text { WECC } & \text { Western Electricity Coordinating Council } \\ \text { WRI } & \text { World Resource Institute }\end{array}$




\section{Idaho National Laboratory's FY12 Greenhouse Gas Report}

\section{INTRODUCTION}

Idaho National Laboratory (INL) has been in operation since 1949. Battelle Energy Alliance (BEA) currently operates INL for the Department of Energy (DOE). In addition to specializing in nuclear energy, INL supports the overall DOE missions in energy research, science, and national defense as indicated in their stated mission to "Ensure the nation's energy security with safe, competitive, and sustainable energy systems and unique national and homeland security capabilities."

The INL Site covers approximately 890 square miles of high-elevation desert in southeastern Idaho and is home to multiple facilities operated by several contractors in addition to BEA. BEA is currently the largest contractor and is responsible for day-to-day management and operation of the Laboratory. Other major contractors currently operating at the INL Site include:

- $\quad$ CH2M WG Idaho manages the Idaho Cleanup Project (ICP), which includes the Idaho Nuclear Technology Center (INTEC) facility and the performance of cleanup work across the INL Site

- Idaho Treatment Group (ITG) operates the Advanced Mixed Waste Treatment Project (AMWTP)

- Bechtel Bettis operates the Naval Reactor Facilities (NRF)

- DOE Idaho Operations Office (DOE-ID).

This report will look exclusively at the greenhouse gas (GHG) emissions that INL (BEA) owns and it is assumed that other contractors will provide similar reporting for the activities they control. All attempts have been made to look only at INL's emissions unless otherwise indicated. In this report "INL" is used to indicate the BEA operations and employees to which this report applies, while "INL Site" will apply to the entire geographical area and all contractors.

INL's employees work at multiple locations throughout the INL Site as indicated in Figure 1. The metropolitan area closest to the Site is Idaho Falls, which is also the location of the Research and Education Campus or "town" facilities. The major campuses within the INL Site where INL employees work include the Advanced Test Reactor (ATR) Complex (45 miles west of Idaho Falls), Materials and Fuels Complex (MFC, 28 miles west of Idaho Falls), and the Specific Manufacturing Capability (SMC, 60 miles northwest of Idaho Falls). The INL Site's large geographical area and long history make for some unique characteristics, including:

- Long Commutes. Approximately half of INL's employees work at Site desert locations, approximately 30 to 50 miles west of Idaho Falls, and ride INL buses or utilize their own personal vehicles to commute to work.

- Large Transportation Fleet. INL operates a large vehicle fleet that includes light-duty passenger vehicles, commercial buses, and off-road equipment. This fleet is being modernized through a transition to General Services Administration (GSA) vehicles. INL's commercial buses are used for transporting employees from all INL Site contractors on their commute to and from the Site facilities. 


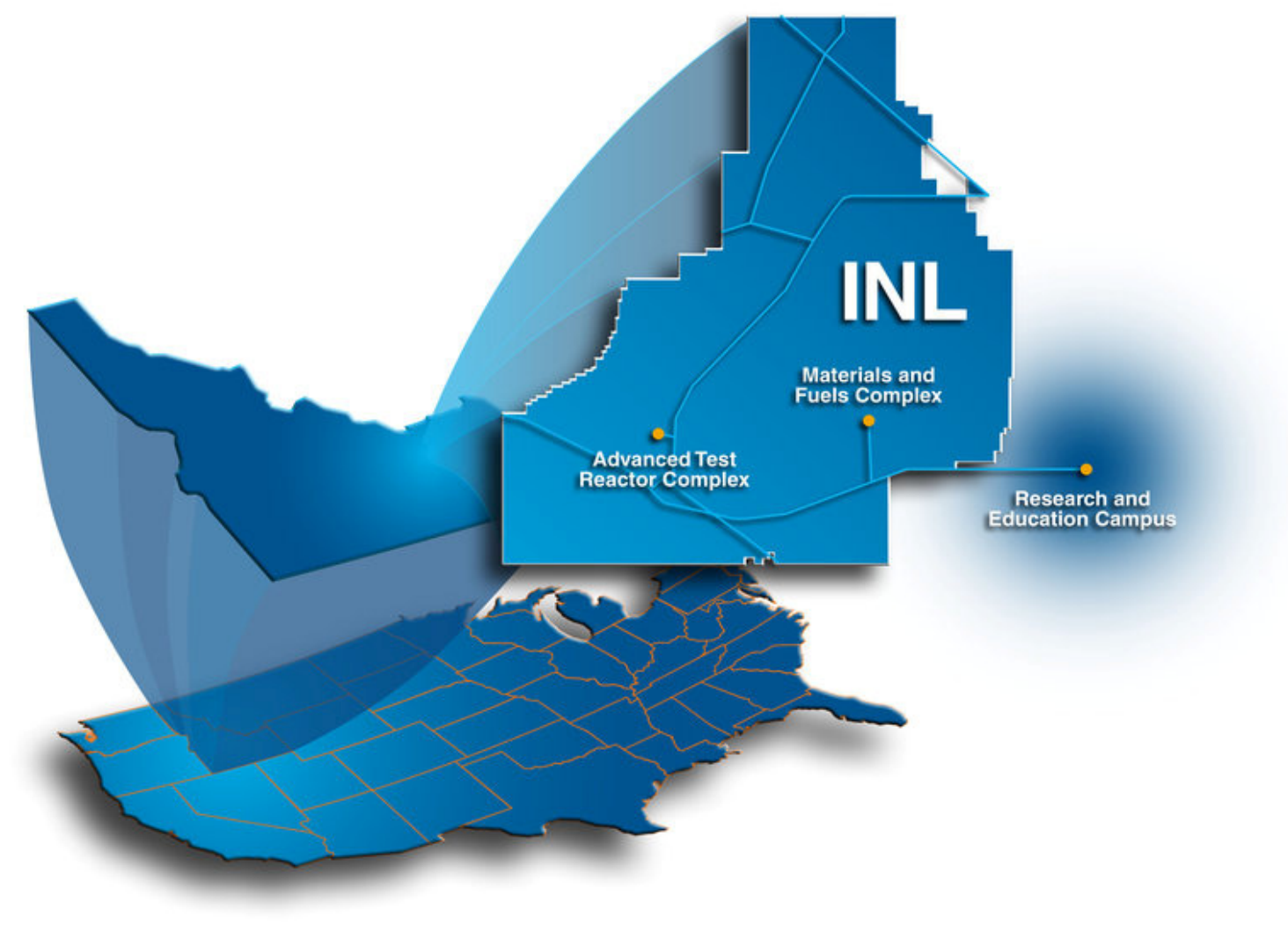

Figure 1. Location map of the INL Site and major facilities.

- Antiquated Facilities. The INL Site includes hundreds of buildings, some of which are DOE-owned, some leased; however, many of these buildings are aged. INL is in the process of modernizing its buildings to support the INL mission, attract and retain its work-force, and satisfy Executive Order (EO) requirements.

On a historical note, INL is home to the peaceful atom - the world's first usable amount of electricity produced from nuclear energy was generated at INL's forerunner, the National Reactor Test Station, in 1951. With such a long history and a commitment to revitalizing nuclear energy, a low-carbon source of energy, it is only appropriate that INL would be interested in lowering its own GHG emissions. The first step to quantifying any GHG savings is to establish a baseline. Fiscal Year (FY) 2008 was chosen as the baseline year since this calculation effort will also support EO 13514, "Federal Leadership in Environmental, Energy, and Economic Performance," requirements to report on and reduce GHG emissions based on an FY08 baseline. This report documents the effort to calculate the GHG emissions for FY12 and compares them to the FY08 baseline results. (For more information on INL's FY08 GHG Baseline results, see INL/EXT-10-19264, "Idaho National Laboratory's Greenhouse Gas FY08 Baseline.")

This report documents the methodology and calculations to determine the INL GHG inventory, and provides perspective on the results of INL's GHG inventory (also referred to as the carbon footprint). Methodology is still being fine-tuned for calculating GHGs, particularly at the federal level where the intent is to standardize the emissions categories considered and the associated calculations to standardize reporting. These GHG inventory calculations follow the most current methodology available: the EO 13514, "Federal Greenhouse Gas Accounting and Reporting Guidance, Revision 1" (referred to herein as the Guidance) [2012], and its accompanying "Federal Greenhouse Gas Accounting and Reporting Guidance: Technical Support Document" (referred to herein as the TSD) [2010]. In addition to 
standardizing the methodology, these documents attempt to best utilize the data that federal facilities are already required to report, such as fuel (for energy and fleet) and electricity usage. The Guidance and TSD uses a combination of existing guidance and regulations as their basis, including:

- The World Resource Institute's (WRI's) and Land Management Institute's (LMI's) Public Sector GHG Accounting and Reporting Standard (Public Sector Standard [PSS])

- Environmental Protection Agency's (EPA's) Climate Leaders Guidance

- EPA's “Final Rule: Mandatory Reporting of Greenhouse Gases" (MRR, 40 CFR 98), as references for their methodologies and emission factors. 


\section{WHY LOOK AT GREENHOUSE GASES?}

INL has many reasons to calculate the organization's GHG emissions, including environmental and political pressures external to INL as well as internal requirements within the Laboratory.

When considering the results of this analysis, it will be important to consider the limits of the analysis. While a GHG inventory is currently the popular method for assessing an organization's environmental impacts, it is focused on just one impact to the earth: climate change. It is important to keep the full lifecycle effects of various sources of environmental impact - including air pollution, habitat degradation, and resource extraction — in mind when making a decision or drawing any overall conclusions.

\subsection{Environmental Motivations}

Environmental impacts come in a variety of forms. Many emitted pollutants have been the subject of historical environmental regulation (e.g., air pollutants by the Clean Air Act of 1963 or water pollutants by the Federal Water Pollution Control Amendments of 1972). Climate change (sometimes called global warming) is a primary focus of current scientific inquiry, and policymaking reflects the current understanding of the impact of GHGs in causing anthropogenic climate change. Policies currently being considered include the introduction of carbon taxes or carbon-emissions trading-a market-based system of incentives aimed at achieving reductions in emissions of GHGs. Such a system might bear similarity to the trading system in place in the United States that regulates $\mathrm{SO}_{2}$ emissions under the Clean Air Act of 1990.

\subsection{Political Motivations}

This effort of identifying and calculating GHG emissions supports Executive Order 13514, "Federal Leadership in Environmental, Energy, and Economic Performance." As the name indicates, the EO requires that federal agencies "lead by example" in measuring, reporting, and reducing GHG emissions. It requires that agencies of the federal government report existing emissions and steps taken to eliminate pollutants in a way that is transparent.

This report represents the effort to catalog INL's contribution to the INL Site carbon footprint. To be in compliance with the EO, some emission metrics must be separated from information that INL already tracks and reports for the entire Site (e.g., fuels and electricity), and several metrics, such as employee commuting and travel, are tracked now to comply with the EO.

\subsection{INL Objectives}

INL chooses to support efforts to monitor and reduce GHG emissions for several reasons. These include an existing Battelle Corporate initiative that seeks to monitor and reduce the corporate contribution to GHG emissions. As a research institution committed to making contributions in the areas of energy research and national security, INL has mission-based interests in the clean, sustainable production of energy. Its historical interest in nuclear reactor testing represents a longstanding commitment to low-carbon power generation.

INL is committed to sustainability. GHG inventory is an accepted method of identifying environmental impacts, and assessing major contributions to GHG emissions and the best methods to reduce them. 


\subsubsection{Sustainable INL}

The Sustainable INL Program is part of a movement among federal agencies to evaluate current processes and establish goals for achieving sustainability. The Sustainable INL mission is to "ensure the nation's energy security with safe, competitive, and sustainable energy systems without compromising the ability of future generations to meet their own needs." Its intent is to continue innovation and research while simultaneously improving energy efficiency, becoming responsible environmental stewards, and conserving natural resources. Focus areas within the program include those covered in EO 13514: energy efficiency, renewable energy, toxics reductions, recycling, sustainable buildings, electronics stewardship, fleet efficiency, and water conservation. Sustainable INL relies on management and employee participation to achieve its goals. For questions specific to Sustainable INL, visit www.inl.gov/sustainable, or contact Chris Ischay (Program Manager, 208-526-4382, Christopher.Ischay@inl.gov) or Ernest Fossum (Energy Manager, 208-526-2513, Ernest.Fossum@,inl.gov). 


\section{CALCULATION APPROACH \\ 3.1 Selected GHG Protocol}

As mentioned in Section 1, these calculations follow the Guidance and the TSD unless otherwise indicated.

\subsection{Defined Inventory Boundaries}

This GHG inventory considers all INL-owned operations, including buildings and employees. As mentioned in the Introduction, several other contractors operate on the INL Site including CH2M-WG Idaho, LLC (CWI), Idaho Treatment Group (ITG), and Bechtel Bettis. Facilities managed by these other contractors were not included in this inventory. Some non-INL employees (including DOE-ID) are located in several INL buildings that were included in these calculations, but since INL pays for the operations (e.g., boiler fuels, electricity, solid waste removal), and thus has operational control, these were counted in the INL inventory. Operations directly associated with the employees of other contractors (such as employee travel and employee commuting) were not included in INL's inventory GHG calculations.

The following metrics are offered to give a sense of scale for INL's and FY12 contributions to the overall INL Site's GHG inventory:

- INL employees (including interns and temporary employees) amounted to 4,083 of the combined 6,000 (approximate) employees at the INL Site during FY12

- The total square footage of buildings owned by INL or occupied by INL personnel and used for INL operations represented $56.5 \%$ of the total 5.39 million square feet that made up the INL Site in FY12 $(63.5 \% \text { of } 509 \text { buildings })^{\mathrm{a}}$

- The percentage of electrical power consumed by INL operations and personnel is $67.2 \%$ of the total 221,512 MWh.

\subsection{Defined Scope}

GHG inventories or footprints consider emissions from three emission scopes (Scope 1, 2, and 3) as indicated in Figure 2, and described below:

- Scope 1: Direct or INL-owned emissions that are produced onsite, such as stationary combustion (from fuel combustion), mobile combustion (from fleet vehicles) and fugitive emissions (from refrigerants, onsite landfills, and onsite wastewater treatment). These include emissions that may benefit another entity or contractor, but for which INL controls or owns the associated process.

- Scope 2: Indirect or shared emissions produced by INL's electricity, heat, and steam purchases. (Note that INL did not purchase heat or steam during FY12.)

- $\quad$ Scope 3: Indirect or shared emissions generated by outsourced activities that benefit INL (occur outside INL's organizational boundaries, but are a consequence of INL's activities). This can include a large number of activities, but for purposes of this inventory, INL focused on transmission and distribution losses, employee commuting, employee travel, contracted waste disposal, and contracted wastewater treatment since these categories were identified in the TSD for required reporting. Other activities that could be included in Scope 3 include the embodied emissions of purchased materials.

a. These are based on the numbers at the end of the FY12 first quarter, which is considered representative for the entire year. INL's portion is based on the buildings that belong to the DOE Nuclear Energy program, while the remaining buildings at the INL Site belong to the Environmental Management program. 


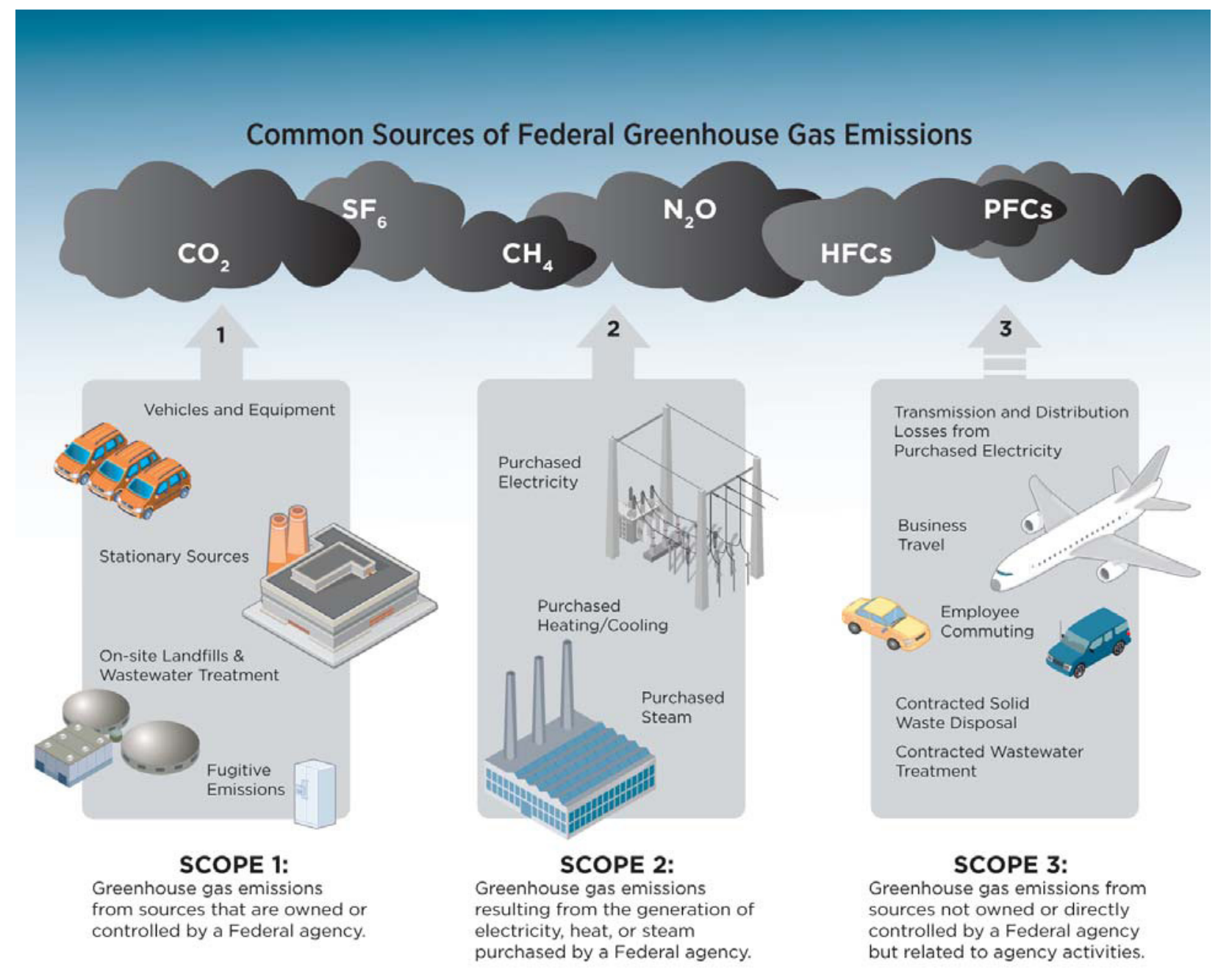

Figure 2. GHG emissions from Scope 1, 2, and 3.

This inventory considered the following six gases: $\mathrm{CO}_{2}, \mathrm{SF}_{6}, \mathrm{CH}_{4}, \mathrm{~N}_{2} \mathrm{O}, \mathrm{HFCs}$, and PFCs, as required by the Guidance. $\mathrm{NF}_{3}$ and other GHGs with high global warming potential (GWP) are identified for optional reporting.

The GWP of the gases considered was used to convert all GHG emissions to units of carbon dioxide equivalent $\left(\mathrm{CO}_{2} \mathrm{e}\right)$, a means of describing the cumulative effect of all GHGs weighted by their 100-year warming potential. The GWP indicates each gas's heat-trapping impact relative to $\mathrm{CO}_{2}$, which has a GWP of 1.0 and functions as a warming index. The GWP values used for the FY12 calculations are based on the EPA MRR and are shown in Appendix A, "Global Warming Potentials."

Table 1 summarizes the GHG emissions categories that were identified in the Guidance and TSD, whether they were calculated for INL's FY12 report, and their reporting status in the Guidance and TSD (identified as required or recommended for reporting). Some Scope 3 GHG sources will not be required reporting until FY13 or later since the calculation method for determining their emissions is still being developed. 
Table 1. GHG emissions categories identified in Guidance and TSD.

\begin{tabular}{|c|c|c|c|}
\hline Scope & Emissions Category & $\begin{array}{l}\text { Calculated for } \\
\text { FY12 }\end{array}$ & Reporting Status in Guidance and TSD \\
\hline \multirow{6}{*}{$\begin{array}{c}1 \\
(\text { Direct })\end{array}$} & $\begin{array}{l}\text { Stationary Combustion } \\
\text { (Boilers, generators, etc.) }\end{array}$ & Yes & $\begin{array}{l}\text { Required reporting in FY08 Baseline } \\
\text { and FY12 Inventory. }\end{array}$ \\
\hline & $\begin{array}{l}\text { Mobile Combustion (Fleet } \\
\text { Vehicles) }^{\mathrm{b}}\end{array}$ & Yes & $\begin{array}{l}\text { Required reporting in FY08 Baseline } \\
\text { and FY12 Inventory. }\end{array}$ \\
\hline & $\begin{array}{l}\text { Fugitive Emissions: } \\
\text { Refrigerants }\end{array}$ & Yes & $\begin{array}{l}\text { Required reporting in FY08 Baseline } \\
\text { and FY12 Inventory. }\end{array}$ \\
\hline & $\begin{array}{l}\text { Fugitive Emissions: Onsite } \\
\text { Landfill }\end{array}$ & Yes & $\begin{array}{l}\text { Required reporting in FY08 Baseline } \\
\text { and FY12 Inventory. }\end{array}$ \\
\hline & $\begin{array}{l}\text { Fugitive Emissions: Onsite } \\
\text { Wastewater Treatment }\end{array}$ & Yes & $\begin{array}{l}\text { Required reporting in FY08 Baseline } \\
\text { and FY12 Inventory. }\end{array}$ \\
\hline & $\begin{array}{l}\text { Industrial Process Emissions } \\
\text { (Manufacturing or } \\
\text { Processing Chemicals or } \\
\text { Materials) }\end{array}$ & $\begin{array}{l}\text { No, INL does } \\
\text { not perform } \\
\text { any of the } \\
\text { activities } \\
\text { listed in the } \\
\text { TSD }\end{array}$ & $\begin{array}{l}\text { Required reporting in FY08 Baseline } \\
\text { and FY12 Inventory. }\end{array}$ \\
\hline \multirow{6}{*}{$\begin{array}{c}2 \\
\text { (Indirect) }\end{array}$} & Purchased Electricity & Yes & $\begin{array}{l}\text { Required reporting in FY08 Baseline } \\
\text { and FY12 Inventory. }\end{array}$ \\
\hline & $\begin{array}{l}\text { Purchased Steam, Hot Water } \\
\text { or Chilled Water }\end{array}$ & $\begin{array}{l}\text { No, INL does } \\
\text { not purchase }\end{array}$ & $\begin{array}{l}\text { Required reporting in FY08 Baseline } \\
\text { and FY12 Inventory. }\end{array}$ \\
\hline & $\begin{array}{l}\text { Combined Heating and } \\
\text { Power }\end{array}$ & $\begin{array}{l}\text { No, INL does } \\
\text { not utilize }\end{array}$ & $\begin{array}{l}\text { Required reporting in FY08 Baseline } \\
\text { and FY12 Inventory. }\end{array}$ \\
\hline & $\begin{array}{l}\text { Purchased Steam from } \\
\text { Waste to Energy }\end{array}$ & $\begin{array}{l}\text { No, INL does } \\
\text { not purchase }\end{array}$ & $\begin{array}{l}\text { Required reporting in FY08 Baseline } \\
\text { and FY12 Inventory. }\end{array}$ \\
\hline & $\begin{array}{l}\text { Transmission \& Distribution } \\
\text { (T\&D) Losses (within INL's } \\
\text { operational controls) }\end{array}$ & Yes & $\begin{array}{l}\text { Required reporting in FY08 Baseline } \\
\text { and FY12 Inventory. }\end{array}$ \\
\hline & $\begin{array}{l}\text { Purchased Green Power } \\
\text { (Renewable Energy } \\
\text { Certificates [RECs]) }\end{array}$ & $\begin{array}{l}\text { Yes, INL } \\
\text { purchased } \\
\text { RECs }\end{array}$ & $\begin{array}{l}\text { Required reporting in FY08 Baseline } \\
\text { and FY12 Inventory. }\end{array}$ \\
\hline \multirow{4}{*}{$\begin{array}{c}3 \\
\text { (Indirect) }\end{array}$} & $\begin{array}{l}\text { T\&D Losses (outside INL's } \\
\text { operational controls) }\end{array}$ & Yes & $\begin{array}{l}\text { Required reporting in FY08 Baseline } \\
\text { and FY12 Inventory. }\end{array}$ \\
\hline & Employee Commuting & Yes & $\begin{array}{l}\text { Required reporting in FY08 Baseline } \\
\text { and FY12 Inventory. }\end{array}$ \\
\hline & Business Air Travel & Yes & $\begin{array}{l}\text { Required reporting in FY08 Baseline } \\
\text { and FY12 Inventory. }\end{array}$ \\
\hline & $\begin{array}{l}\text { Business Ground Travel: } \\
\text { Rental Vehicle }\end{array}$ & Yes & $\begin{array}{l}\text { Required reporting in FY08 Baseline } \\
\text { and FY12 Inventory. }\end{array}$ \\
\hline
\end{tabular}

b. This includes $\mathrm{CH}_{4}$ and $\mathrm{N}_{2} \mathrm{O}$ from biofuel blends. Per the TSD, biogenic $\mathrm{CO}_{2}$ emissions generated from combustion of biofuels are counted separately since this carbon would have been released through the plant's natural decomposition. 
Table 1. (continued).

\begin{tabular}{|c|c|c|c|}
\hline Scope & Emissions Category & $\begin{array}{l}\text { Calculated for } \\
\text { FY12 }\end{array}$ & Reporting Status in Guidance and TSD \\
\hline & $\begin{array}{l}\text { Business Ground Travel: } \\
\text { Personal Vehicle }\end{array}$ & Yes & $\begin{array}{l}\text { Required reporting in FY08 Baseline } \\
\text { and FY12 Inventory. }\end{array}$ \\
\hline & $\begin{array}{l}\text { Contracted Municipal Solid } \\
\text { Waste (MSW) Disposal }\end{array}$ & Yes & $\begin{array}{l}\text { Required reporting in FY08 Baseline } \\
\text { and FY12 Inventory. }\end{array}$ \\
\hline & $\begin{array}{l}\text { Contracted Wastewater } \\
\text { Treatment }\end{array}$ & Yes & $\begin{array}{l}\text { Required reporting in FY08 Baseline } \\
\text { and FY12 Inventory. }\end{array}$ \\
\hline & $\begin{array}{l}\text { Vendor and Contractor } \\
\text { Emissions (Indirect } \\
\text { emissions in the supply } \\
\text { chain) }\end{array}$ & $\begin{array}{l}\text { No, will wait } \\
\text { for additional } \\
\text { guidance. }\end{array}$ & $\begin{array}{l}\text { Do not require reporting at this time, } \\
\text { but future inventories will include these } \\
\text { emissions. It is expected that this } \\
\text { category will be a large contributor to } \\
\text { INL's GHG inventory. }\end{array}$ \\
\hline & Fuel Production & No & $\begin{array}{l}\text { Do not require reporting at this time, } \\
\text { but future inventories are expected to } \\
\text { include these emissions. }\end{array}$ \\
\hline & $\begin{array}{l}\text { Land Management (changes } \\
\text { that sequester or release } \\
\text { GHGs) }\end{array}$ & No & Do not require reporting at this time. \\
\hline & $\begin{array}{l}\text { Biomass Combustion, } \\
\text { Enteric Fermentation, } \\
\text { Composting and Manure } \\
\text { Management }\end{array}$ & $\begin{array}{l}\text { No, INL does } \\
\text { not perform. }\end{array}$ & Do not require reporting at this time. \\
\hline \multirow{4}{*}{ Biogenic $^{c}$} & Mobile Combustion & Yes & $\begin{array}{l}\text { Required reporting in FY08 Baseline } \\
\text { and FY12 Inventory. }\end{array}$ \\
\hline & Stationary Combustion & $\begin{array}{l}\text { No, INL did } \\
\text { not utilize } \\
\text { biofuels for } \\
\text { this category. }\end{array}$ & $\begin{array}{l}\text { Required reporting in FY08 Baseline } \\
\text { and FY12 Inventory. }\end{array}$ \\
\hline & $\begin{array}{l}\text { Fugitive Emissions: Onsite } \\
\text { Landfill }\end{array}$ & Yes & $\begin{array}{l}\text { Required reporting in FY08 Baseline } \\
\text { and FY12 Inventory. }\end{array}$ \\
\hline & Contracted MSW Disposal & Yes & $\begin{array}{l}\text { Required reporting in FY08 Baseline } \\
\text { and FY12 Inventory. }\end{array}$ \\
\hline
\end{tabular}

c. Note that biogenic emissions will not count against GHG reduction targets. 
As shown in Table 1, the TSD differentiates between anthropogenic and biogenic emissions for reporting purposes. Anthropogenic emissions are those that are human caused, while biogenic emissions are considered to be those that would have been released due to naturally occurring processes (without human involvement). For example, when considering the combustion of biofuels versus fossil fuels, the carbon from biofuels is absorbed from the atmosphere during plant growth and recycled during the natural decomposition process; therefore, the combustion of biofuels is considered biogenic, while the carbon from fossil fuels has been locked in the earth for millennia and will yield a net increase in atmospheric carbon relative to what would have occurred naturally. Although the TSD requires reporting of biogenic emissions, they will not count against an agency's GHG reduction targets; therefore, INL will focus on their anthropogenic emissions.

\subsection{Identified Greenhouse Gas Emissions Categories}

After identifying which GHG emission categories in Table 1 would need to be calculated for INL, the next step is to identify where to find the INL-specific organizational data for performing the calculations. Table 2 summarizes the INL-specific data sources for each emissions category.

Table 2. INL's GHG emissions categories for Scopes 1, 2, and 3.

\begin{tabular}{|c|c|c|}
\hline Scope & Emissions Category & INL Data Source \\
\hline \multirow{5}{*}{$\begin{array}{c}1 \\
\text { (Direct) }\end{array}$} & $\begin{array}{l}\text { Stationary Combustion (Boilers, } \\
\text { generators, etc.) }\end{array}$ & $\begin{array}{l}\text { Fuel consumption reports (INL's Quarterly } \\
\text { Energy Reports and Fuel Sheets) }\end{array}$ \\
\hline & $\begin{array}{l}\text { Mobile Consumption (Fleet } \\
\text { Vehicles) }\end{array}$ & $\begin{array}{l}\text { Fuel consumption database (Transportation } \\
\text { Issues Management System [TIMS]) and Fuel } \\
\text { Sheets }\end{array}$ \\
\hline & Fugitive Emissions: Refrigerants & $\begin{array}{l}\text { Refrigerant purchases, use, and disposal } \\
\text { (Comply Plus Database) }\end{array}$ \\
\hline & Fugitive Emissions: Onsite Landfill & $\begin{array}{l}\text { INL Landfill records (INEEL Nonradiological } \\
\text { Waste Management Information System } \\
\text { [INWMIS]) }\end{array}$ \\
\hline & $\begin{array}{l}\text { Fugitive Emissions: Onsite } \\
\text { Wastewater Treatment }\end{array}$ & INL's Environmental Support \& Services staff \\
\hline \multirow{2}{*}{$\begin{array}{c}2 \\
\text { (Indirect) } \\
\end{array}$} & Purchased Electricity & INL's Quarterly Energy Reports \\
\hline & Purchased RECs & RECs Purchase Documentation \\
\hline \multirow{7}{*}{$\begin{array}{c}3 \\
\text { (Indirect) }\end{array}$} & T\&D Losses & INL's Quarterly Energy Reports \\
\hline & Employee Commuting & FY12 Employee Commute Survey Results \\
\hline & Business Air Travel & INL Travel Office \\
\hline & $\begin{array}{l}\text { Business Ground Travel: Rental } \\
\text { Vehicle }\end{array}$ & INL Travel Office \\
\hline & $\begin{array}{l}\text { Business Ground Travel: Personal } \\
\text { Vehicle }\end{array}$ & INL Travel Office \\
\hline & Contracted MSW Disposal & City of Idaho Falls Sanitation invoice records \\
\hline & Contracted Wastewater Treatment & City of Idaho Falls \\
\hline \multirow[t]{3}{*}{ Biogenic } & Mobile Combustion & Fuel consumption databases (TIMS) \\
\hline & Fugitive Emissions: Onsite Landfill & INL Landfill records (INWMIS) \\
\hline & Contracted MSW Disposal & City of Idaho Falls Sanitation invoice records \\
\hline
\end{tabular}


The identification of sources of information for the different emissions allows for the:

- Collecting of necessary data from sources identified in Table 2.

- Gathering of necessary emissions factors (the TSD was consulted as a primary document, and then the EPA's Climate Leaders guidance was referenced if the applicable emissions factors were not available in the TSD).

- Calculating inventory of INL's GHG emissions categories. For each emissions category, the GHG emissions were calculated in metric tons of $\mathrm{CO}_{2} \mathrm{e}$ based on INL-specific data, emission factors, and applicable GWPs. (A sample calculation is shown in Appendix B, "Sample Calculation.") The majority of these calculations were performed following the TSD, with Excel spreadsheets prepared specifically for establishing INL's GHG inventory. Exceptions to this process are noted in the sections below and include the emissions from the onsite landfill, which were calculated using an EPA model (per the TSD). 


\section{DISCUSSION AND RESULTS \\ 4.1 Summary}

Table 3 and Figure 3 through Figure 5 summarize the GHG emissions from INL during FY12. Details on the emission factors and calculation methods used, as well as a discussion of the individual results, follow in the sections below.

Table 3. INL's GHG emissions during FY12.

\begin{tabular}{|c|c|c|}
\hline Scope & Emissions Category & $\begin{array}{c}\text { FY12 GHG Emissions } \\
\left(\mathrm{MT} \mathrm{CO}_{2} \mathrm{e}\right)\end{array}$ \\
\hline \multirow{6}{*}{$\begin{array}{c}1 \\
\text { (Direct) }\end{array}$} & Stationary Combustion & $5,682.00$ \\
\hline & Mobile Combustion & $6,833.91$ \\
\hline & Fugitive Emissions: Refrigerants & 480.96 \\
\hline & Fugitive Emissions: Onsite Landfill & $5,617.08$ \\
\hline & Fugitive Emissions: Onsite Wastewater Treatment & 131.2 \\
\hline & SCOPE 1 TOTAL & $18,745.15$ \\
\hline \multirow{4}{*}{$\begin{array}{c}2 \\
\text { (Indirect) }\end{array}$} & Purchased Electricity & $55,569.91$ \\
\hline & Transmission \& Distribution Losses (Owned) & 975.39 \\
\hline & Purchased RECs & $(14,082.27)$ \\
\hline & SCOPE 2 TOTAL & $42,463.03$ \\
\hline \multirow{8}{*}{$\begin{array}{c}3 \\
\text { (Indirect) }\end{array}$} & Transmission \& Distribution Losses (Shared) & $3,662.06$ \\
\hline & Employee Commuting & $8,313.16$ \\
\hline & Business Air Travel & $4,364.11$ \\
\hline & Business Ground Travel: Rental Vehicle & 299.78 \\
\hline & Business Ground Travel: Personal Vehicle & 251.34 \\
\hline & Contracted MSW Disposal & 852.97 \\
\hline & Contracted Wastewater Treatment & 13.22 \\
\hline & SCOPE 3 TOTAL & $17,756.64$ \\
\hline \multicolumn{2}{|r|}{ TOTAL ANTHROPOGENIC EMISSIONS $^{\mathrm{d}}$} & $78,964.82$ \\
\hline \multirow[t]{3}{*}{ Biogenic } & Mobile Combustion & $1,854.72$ \\
\hline & Fugitive Emissions: Onsite Landfill & 815.5 \\
\hline & Contracted MSW Disposal & 111.7 \\
\hline \multicolumn{2}{|r|}{ TOTAL BIOGENIC EMISSIONS } & $2,781.92$ \\
\hline \multicolumn{2}{|r|}{ TOTAL EMISSIONS (ANTHROPOGENIC + BIOGENIC) } & $81,746.74$ \\
\hline
\end{tabular}

d. These are the numbers that INL will report as their overall emissions. Furthermore, this is the number that INL will be trying to reduce in future years. 


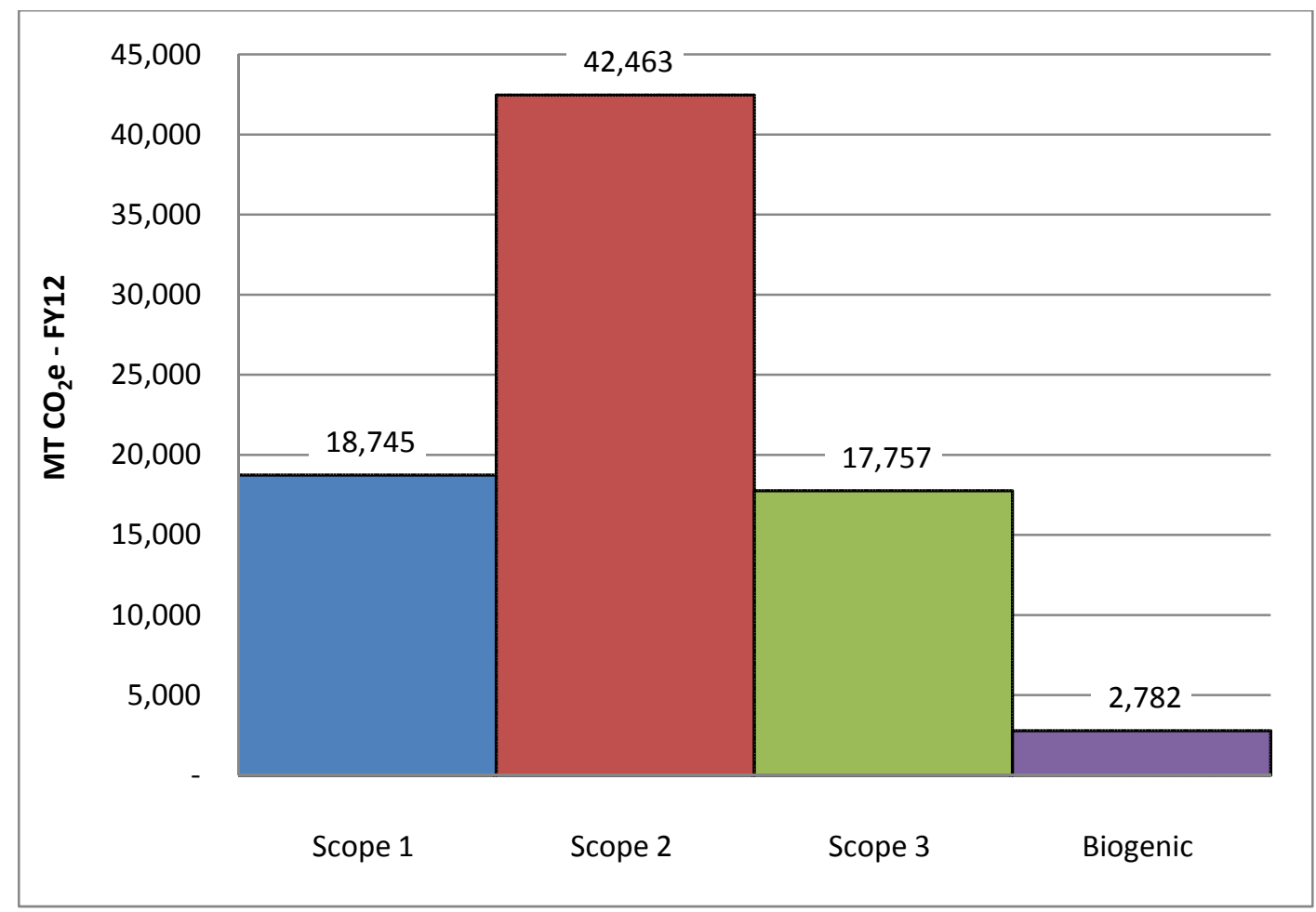

Figure 3. INL's FY12 GHG emissions, by scope.

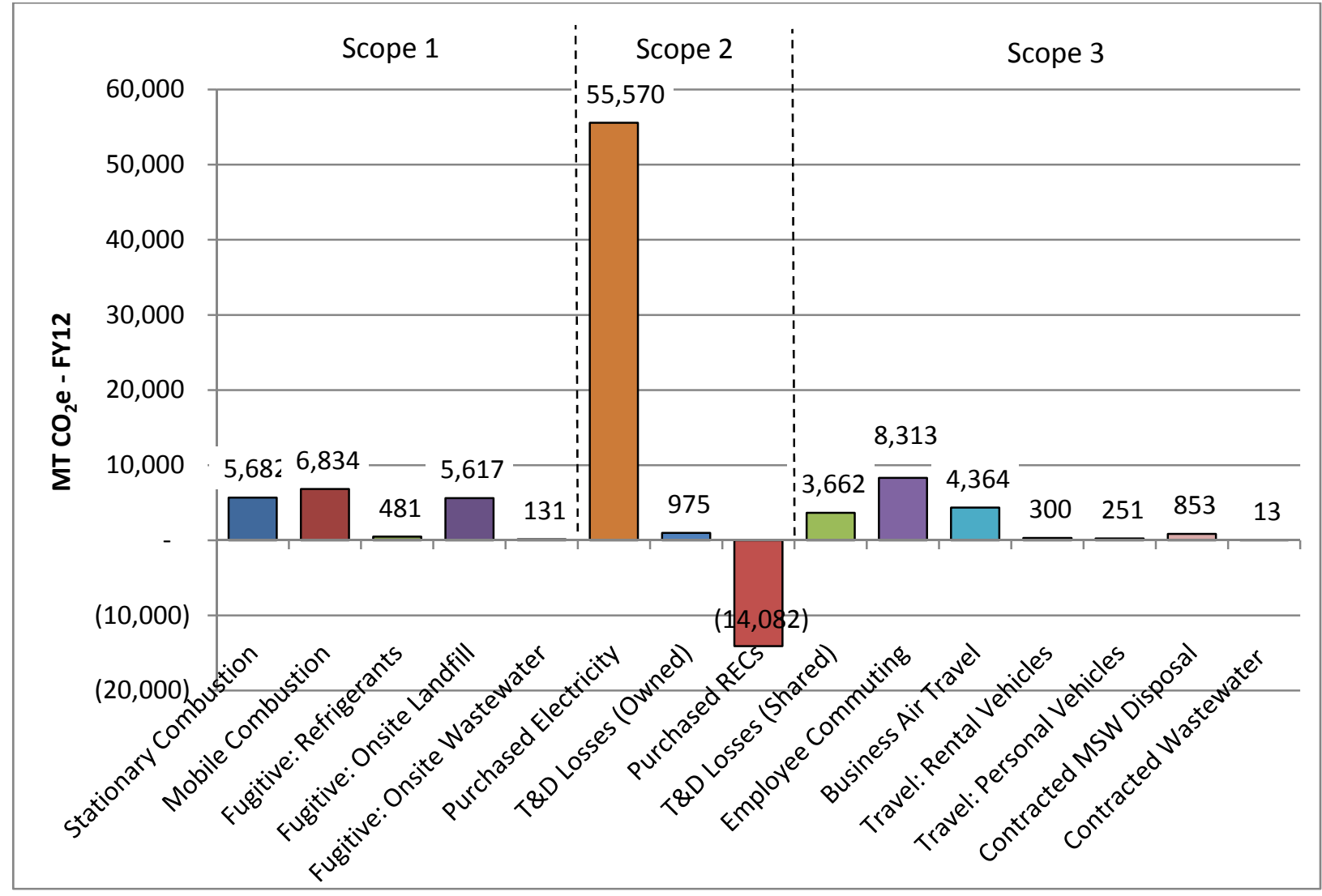

Figure 4. INL's FY12 GHG emissions, by scope and emissions category, excluding biogenic emissions. 


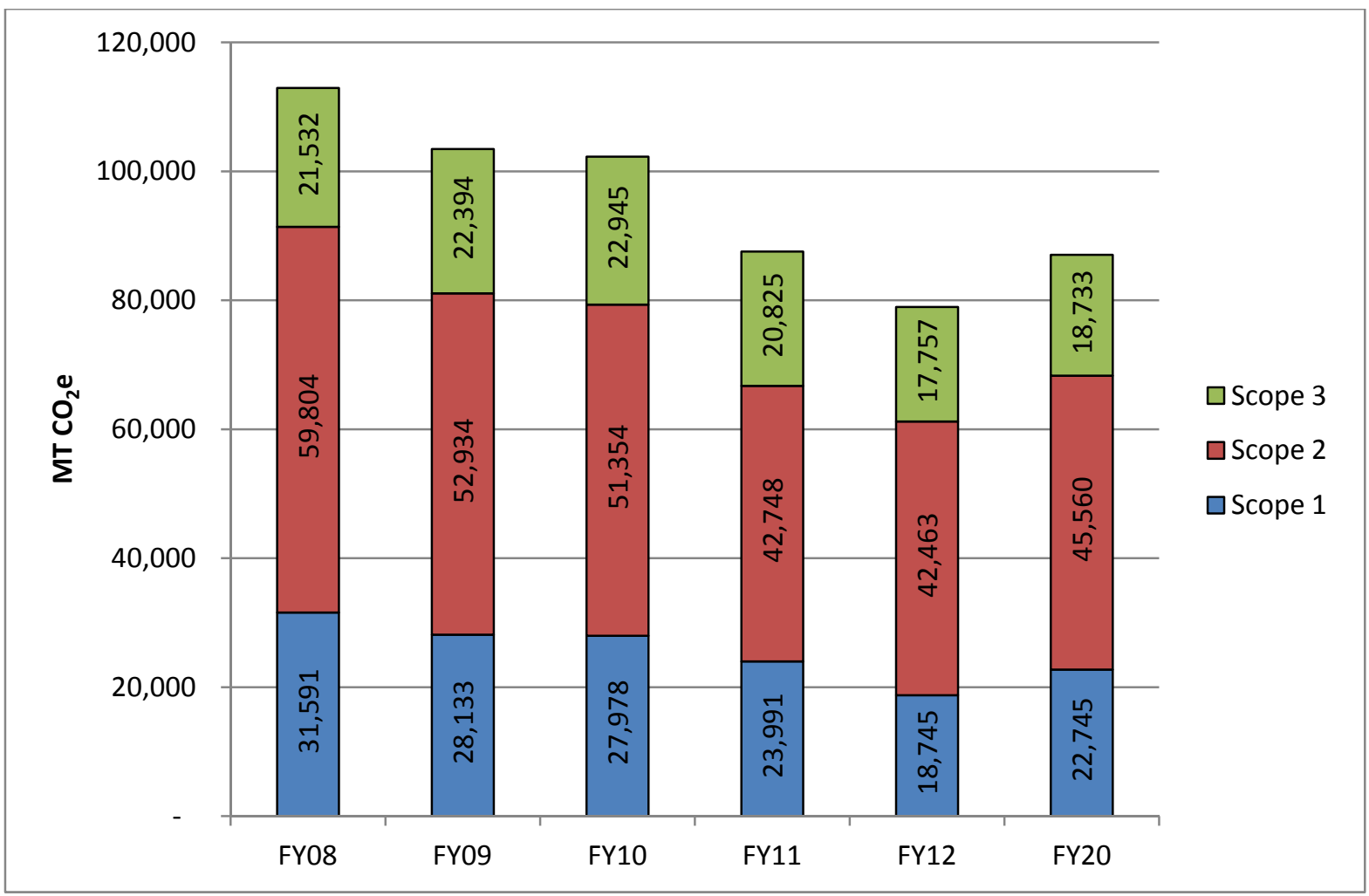

Figure 5. Comparison of INL's FY08, FY09, FY10, FY11, and FY12 GHG emissions, by scope and emissions category, excluding biogenic emissions.

\subsection{Scope One - Direct Emissions}

INL's FY12 Scope 1 emissions are summarized in Figure 6, with a comparison to the FY08 baseline shown in Figure 7. A discussion of each of the Scope 1 emissions categories follows and includes the calculation methods, the significance of the results, lessons learned from the data collection and calculation process, and a comparison to the FY08 baseline results. A comprehensive table, as well as the FY08 baseline emissions and the subsequent FY data, is included in Appendix C, "Scope 1

Comprehensive Tables." 


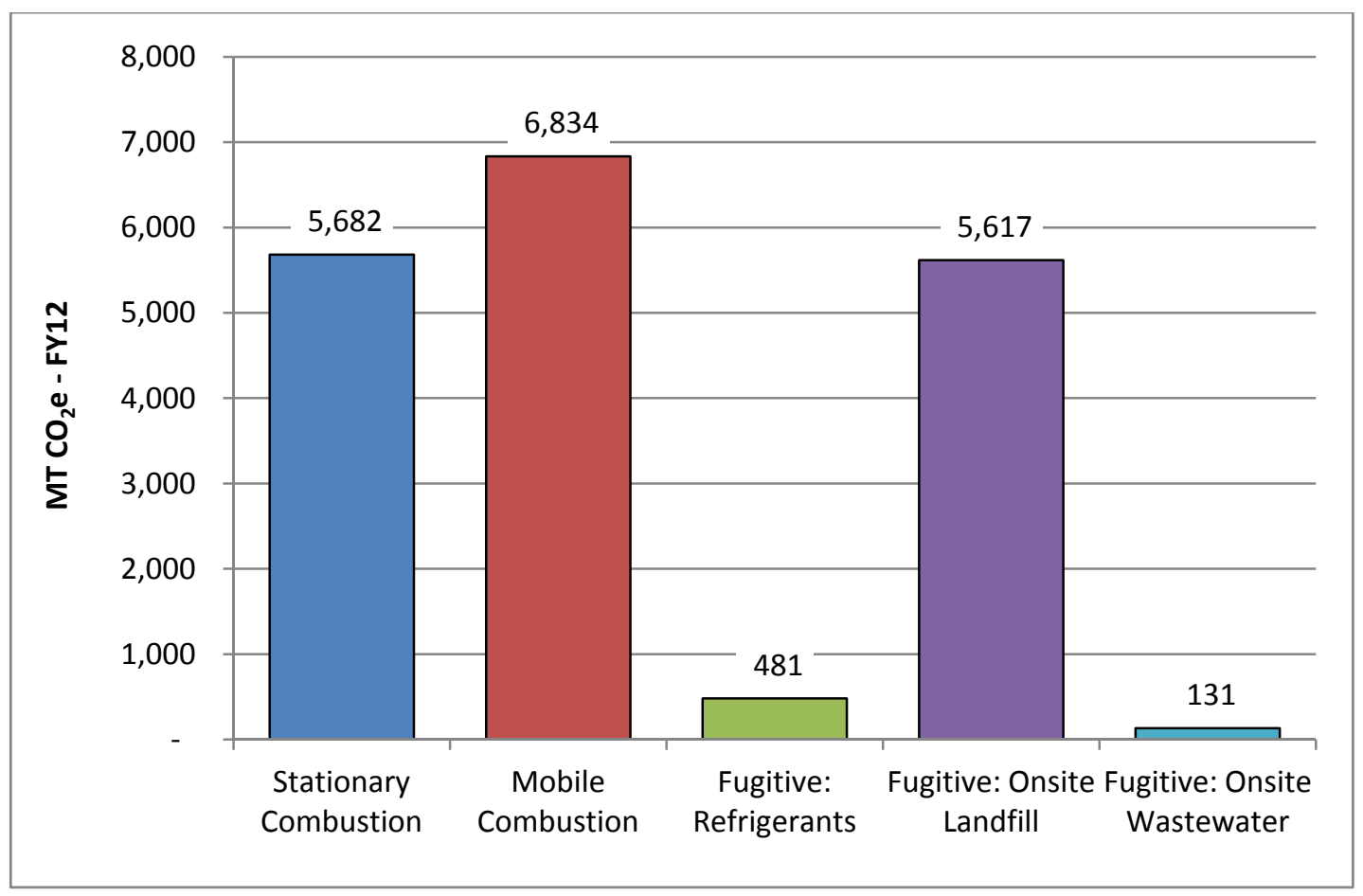

Figure 6. INL's FY12 GHG emission results for Scope 1.

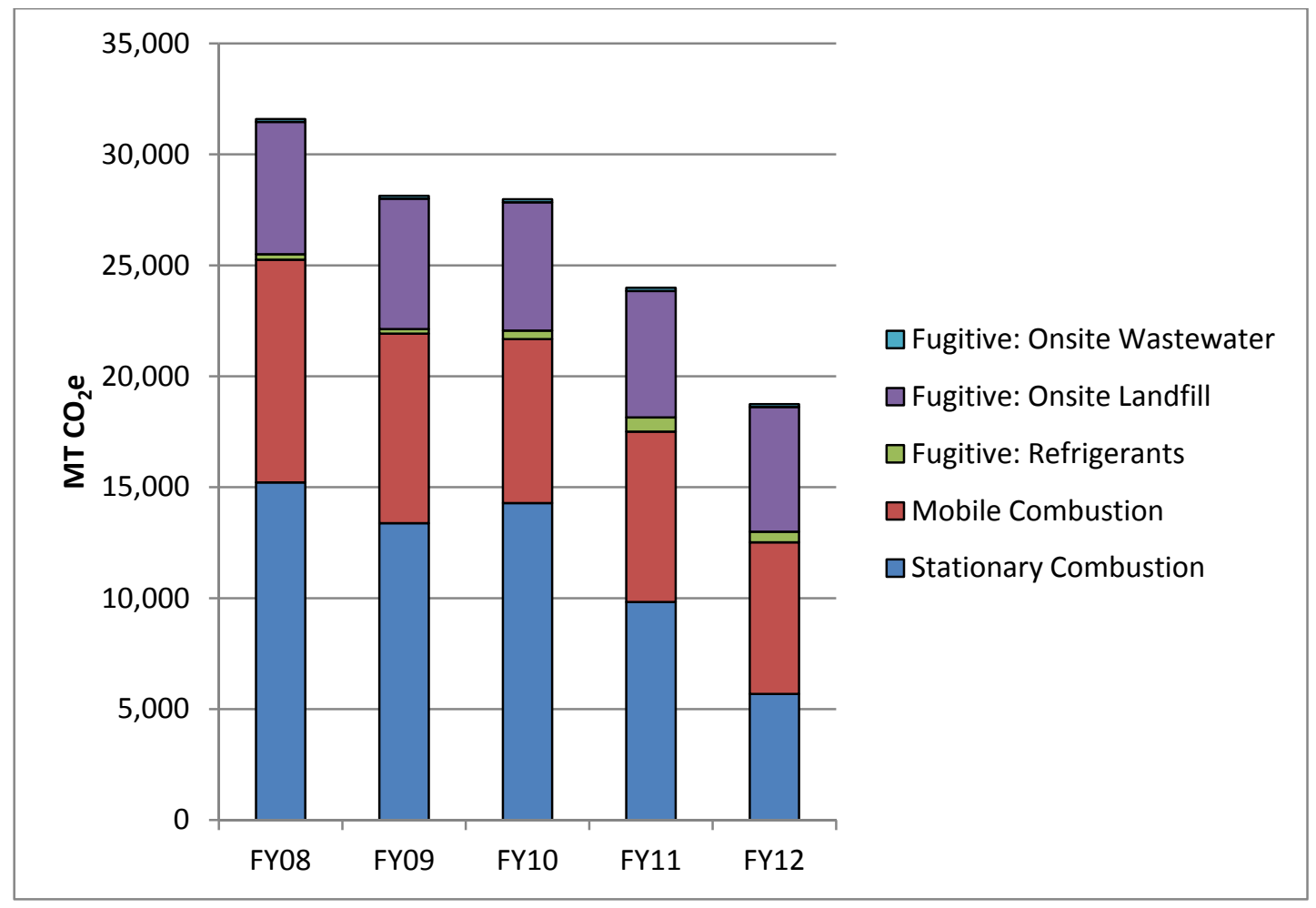

Figure 7. Comparison of INL's FY08, FY09, FY10, FY11, and FY12 Scope 1 GHG emissions. 


\subsubsection{Stationary Combustion Emissions}

\subsubsection{Calculation Method}

To estimate the GHG emissions of INL's stationary combustion from boilers and generators, the default methodology identified in the TSD was adopted. This consisted of obtaining the total amount of fuels used (purchased) onsite by INL. Since these data are also submitted for the Consolidated Energy Date Report (CEDR), and are already tracked for the INL Site, the only calculations needed were to isolate the emissions that INL owns from those owned by other INL Site contractors by separating the fuels purchased for INL-operated facilities.

\subsubsection{Results Discussion}

During FY12 INL used the types and amounts of fuel shown in Table 4 for stationary combustion.

Table 4. Amounts of fuel used for stationary combustion at INL during FY12.

\begin{tabular}{|l|c|c|c|}
\hline \multirow{2}{*}{\multicolumn{1}{|c|}{ Energy Type }} & \multicolumn{2}{c|}{ Fuel Used } & \multirow{2}{*}{$\begin{array}{c}\text { GHG Emissions } \\
\left(\mathrm{MT} \mathrm{CO}_{2} \mathrm{e}\right)\end{array}$} \\
\cline { 2 - 3 } & Amount & Units & $3,805.36$ \\
\hline Fuel Oil No. 2 & 371,587 & Gallons & 266.79 \\
\hline Liquefied Natural Gas (LNG) & 36,263 & Gallons & 310.43 \\
\hline Liquefied Propane Gas (LPG) & 53366 & Gallons & $1,299.41$ \\
\hline Natural Gas (Pipeline) & 245,554 & Therms & $5,682.00$ \\
\hline \multicolumn{3}{|r}{} \\
\hline
\end{tabular}

As shown in Table 4, INL's stationary combustion emissions were calculated to produce 5,682 MT $\mathrm{CO}_{2} \mathrm{e}$ in FY12. In FY12, this equates to 30.3\% of INL's Scope 1 emissions, and $6.5 \%$ of the total anthropogenic emissions considered.

Since these data are already collected and reported annually for the CEDR, they are considered to be of high quality.

\subsubsection{Lessons Learned}

Since the data are already gathered at INL for the CEDR, no changes are needed for reporting in future years. In addition, the data are considered accurate, with all INL-owned sources of stationary combustion included.

\subsubsection{Comparison to FY08 Baseline}

The FY12 results showed a $62.7 \%$ decrease over the FY08 baseline. Looking closer at the differences between the four fuel types showed a 70.2\% decrease in diesel, $16.8 \%$ decrease in LNG deliveries (to the Site), $64.3 \%$ decrease in propane deliveries, and a 3.8\% increase in natural gas (to town facilities).

MFC discontinued use of diesel-fueled boilers in 2011 and 2012, resulting in a significant decrease in diesel usage compared to FY08. Also, winter temperatures in 2011 were warmer than previous years. As for the changes in natural gas at town facilities, several new buildings (UB1-UB4, RESL) came online in between FY09 and FY12, which likely accounts for the increased use in FY12. 


\subsubsection{Mobile Combustion Emissions}

INL operates a large vehicle fleet that includes everything from light-duty passenger vehicles to commercial buses to off-road equipment (including bulldozers, backhoes, cranes, road graders, dump trucks, tractors, manlifts, and even a compactor for the onsite landfill). This fleet is being modernized by a variety of methods to lower overall fuel consumption and increase the use of alternative fuels, including the following:

- Switched to using B20 biodiesel blend for year-round use, rather than using a B10 and B20 winter/summer blend throughout the year (formerly averaged as B15).

- Increased overall bus efficiencies by implementing express routes and eliminating underutilized routes. This was in conjunction with continued efforts in rightsizing the fleet with more flex-fuel vehicles and hybrids.

- Incorporated the Park and Ride concept to reduce bus fuel usage, and developed additional Park and Ride lots for employees at outlying locations.

- Used innovative technology to track and reduce fuel usage such as Global Positioning System (GPS), Radio Frequency Identification (RFID) fuel rings, and data logger technology to monitor engine performance and driver habits.

INL's commercial buses are used for transporting other INL Site contractor employees, as well as BEA employees, on their commute to and from the Site facilities. Since INL owns the bus operations for all Site contractors, these emissions are considered Scope 1 for INL.

\section{During FY12, INL continued to:}

- Research methods to use biodiesel blends in the bus fleet year around, reducing the need for $100 \%$ diesel.

- Improve the Reduce Idle Campaign that is saving fuel by better managing idling times. Results are positive as this campaign is saving 1,400 gal of fuel per month.

- Right size the fleet with more fuel efficient vehicles.

\subsubsection{Calculation Method}

To calculate the GHG emissions from INL's mobile combustion sources, a combination of the default and advanced methodology from the TSD were used. INL tracks the majority of its fuel usage in the TIMS, which tracks fuel used by vehicle type for road vehicles (when fuel taxes are paid), as well as a number of other vehicle metrics. A small portion of INL's fuel use is tracked with fuel sheets for off-road equipment (for which no fuel taxes are paid).

Since the amount of each type of fuel consumed by general vehicle type (bus, light-duty truck, light-duty car, equipment, and heavy-duty truck) was known (see Table 5), more specific $\mathrm{CH}_{4}$ and $\mathrm{N}_{2} \mathrm{O}$ emission factors were used than what is assumed for the TSD default methodology. Since the number of miles traveled by vehicle type is not tracked accurately (some employees bypass inputting this value while refueling), the average mileage by vehicle type was used to calculate this value. For $\mathrm{CH}_{4}$ and $\mathrm{N}_{2} \mathrm{O}$ emission factors based on the vehicle's emission control technology (approximated by the vehicle model year) conservative assumptions were made as indicated in Appendix D, "Emissions Factors Used." 


\subsubsection{Results Discussion}

During FY12, INL used a combination of fossil fuels and biofuels to power its diverse vehicle fleet as shown in Table 5. Per the TSD, the $\mathrm{CO}_{2}$ emissions from biofuels are to be considered biogenic rather than anthropogenic emissions ${ }^{\mathrm{e}}$; therefore, they were calculated and reported separately.

Table 5. Fuel amounts and corresponding GHG emissions for INL's FY12 fleet.

\begin{tabular}{|c|c|c|c|c|}
\hline Fuel Type & Vehicle Type & $\begin{array}{l}\text { Fuel Used } \\
\text { (gal) }\end{array}$ & $\begin{array}{c}\text { GHG } \\
\text { Emissions } \\
\left(\mathrm{MT} \mathrm{CO}_{2} \mathrm{e}\right)\end{array}$ & $\begin{array}{l}\text { Biogenic } \\
\text { Emissions } \\
\left(\mathrm{MT} \mathrm{CO}_{2} \mathrm{e}\right)\end{array}$ \\
\hline \multirow[t]{4}{*}{ B20 Biodiesel Blend $^{\text {f }}$} & Bus & $389,607.82$ & $3,184.95$ & 736.48 \\
\hline & Equipment & $4,026.97$ & 33.24 & 5.71 \\
\hline & Heavy Duty & 765.48 & 6.26 & 1.45 \\
\hline & Light-Duty Truck & --- & --- & --- \\
\hline \multirow[t]{4}{*}{ Diesel } & Bus & $106,683.01$ & $1,089.88$ & - \\
\hline & Equipment & $46,311.52$ & 476.97 & - \\
\hline & Heavy Duty & $26,717.37$ & 273.07 & - \\
\hline & Light-Duty Truck & $6,966.56$ & 71.16 & - \\
\hline \multirow[t]{5}{*}{ E10 Ethanol Fuel Blend } & Bus & --- & --- & --- \\
\hline & Equipment & $23,021.54$ & 184.29 & 13.23 \\
\hline & Heavy Duty & $3,464.86$ & 29.08 & 1.99 \\
\hline & Light-Duty Car & $1,625.20$ & 13.38 & 0.93 \\
\hline & Light-Duty Truck & $133,636.56$ & $1,114.90$ & 76.83 \\
\hline \multirow[t]{4}{*}{ E85 Ethanol Fuel Blend } & Equipment & $1,367.85$ & 2.29 & 6.68 \\
\hline & Light-Duty Car & $7,302.10$ & 13.17 & 35.68 \\
\hline & Light-Duty Truck & $199,673.62$ & 341.30 & 975.73 \\
\hline & TOTAL & $951,170.45$ & $6,833.91$ & $1,854.72$ \\
\hline
\end{tabular}

As shown in Table 5, INL's mobile combustion emissions were calculated to produce 6,833.9 MT $\mathrm{CO}_{2} \mathrm{e}$ of anthropogenic and 1,855 MT CO $2 \mathrm{e}$ of biogenic GHG emissions in FY12. In FY12 this equates to $36.5 \%$ of INL's Scope 1 emissions, and $7.8 \%$ of the total FY12 anthropogenic emissions considered.

Since these data are already collected in TIMS and fuel sheets, they are considered to be of high quality, with all INL-owned sources of mobile combustion included.

\footnotetext{
e. Although a controversial position, the TSD states that biogenic emissions in the form of $\mathrm{CO}_{2}$ emissions generated from biofuel combustion are to be counted separately since this carbon would have been released through the plant's natural decomposition. The $\mathrm{CH}_{4}$ and $\mathrm{N}_{2} \mathrm{O}$ emissions from the combustion of biofuel blends are not considered biogenic emissions.

f. See previous footnote.
} 


\subsubsection{Lessons Learned}

Since the data for calculating GHG emissions from mobile combustion are already gathered at INL with TIMS, no major changes are needed for reporting in future years. However, there are a few tracking and reporting items that could slightly improve the overall accuracy. As discussed above, the accuracy of the calculations could be improved slightly if the total miles driven were tracked along with the gallons of fuel consumed in each vehicle, and more specific vehicle information, including model year, was reported when determining the applicable $\mathrm{CH}_{4}$ and $\mathrm{N}_{2} \mathrm{O}$ emission factors. (Both mileage and emissions control technology affect the GHG contributions from $\mathrm{CH}_{4}$ and $\mathrm{N}_{2} \mathrm{O}$, which are a small portion of the GHG compared to the $\mathrm{CO}_{2}$ contribution.) Furthermore, other INL Site contractors' fuel use is tracked in TIMS and not readily identified as non-INL use that can be separated from INL's numbers. This includes NRF general use and when INL rents heavy equipment to other contractors, but these are a very small portion of the total INL use. ${ }^{\mathrm{g}}$

\subsubsection{Comparison to FY08 Baseline}

In FY12, there was a 31.9\% decrease in GHG emissions from mobile combustion sources over the FY08 baseline. When considering the differences between the total amounts of fuel consumed between these years, there was an 8.9\% decrease in total gallons between FY12 and FY08.

In addition to the changes to the fleet discussed above, the largest contributor to the decrease in GHG emissions is due to the changes in fuel types used since FY08. The largest fuel user at INL is the buses that moved away from LNG (small amount of fuel used in FY08) and diesel (large amount of fuel used in FY08) to biodiesel (B15 and B20 blends). Furthermore, in light-duty vehicles ethanol (E85) replaced gasoline use. These changes yielded a decrease in the associated anthropogenic emissions, and an increase in biogenic emissions.

\subsubsection{Fugitive Emissions: Refrigerants}

Fugitive emissions from refrigerants and fluorinated gases are those GHG emissions from equipment and vehicles that are not captured or destroyed by an emissions control system (those that do not pass through a stack, chimney, etc.).

\subsubsection{Calculation Method}

DOE Headquarters (DOE-HQ) publicized a data call in October 2010 for each facility's FY10 fugitive emissions from refrigerants and fluorinated gases that focused on the gases listed in Table 6, identified by their Chemical Abstract Service (CAS) number. No updated guidance was included in the 2012 Consolidated Energy Data Report (CEDR) data call, so the list of gases provided in FY10 was used for FY12. Note that the calculation methodologies for the 2012 CEDR differ significantly from the TSD; therefore, the results vary greatly. As INL's inventory system does not allow for returning products to supply, the entire received product was assumed used or released according to the CEDR spreadsheet calculations. The TSD takes several other factors into consideration when calculating emissions, including inventory differences at beginning and end of the reporting year and how much product was received, used, recovered, or disposed. The TSD methodology was followed for this report for consistency with previous inventories. To evaluate INL's fugitive emissions during FY12, data from the following sources was reviewed:

- Purchase, usage, and disposal data contained in INL's chemical inventory database, Comply Plus

- Use and disposal information contained on Refrigeration Service Records

g. Tad Pearson confirmed these small uses of INL's fuel by other INL Site contractors in a December 22, 2010 phone call. 
- Transaction and adjustment detail reports pulled from Comply Plus database for each CAS number

- Integrated Waste Tracking System (IWTS) database queries to identify any additional disposal of refrigerants.

Queries were run in Comply Plus for the different outcomes during FY12 using the CAS numbers. Additionally, INL obtained electronic and hard copies of the refrigerant service records from different facilities. These records were reviewed to determine if there was a difference between the amount of refrigerant recovered from a system and its total full capacity. If fewer refrigerants were recovered than the system's full charge amount, the difference was determined to have been released (used). If there was no difference, then there was no release. Additionally, if the refrigerant service record indicated the equipment would be disposed, any difference in the amount recovered and the full charge was considered a released (used) amount. If refrigerants were disposed, the quantity indicated on the refrigerant service record was included as disposed on the spreadsheet. Transaction detail reports were run in Comply Plus for each CAS number for the specific date range to ensure no duplicate entries from the refrigerant service record and the information maintained in Comply Plus. Any duplicate data was removed from the total amount reported. Adjustment queries were also run in Comply Plus to account for "manual" changes to inventory data that is not included in the transaction detail reports. These "manual" changes typically occur during chemical inventories performed by chemical coordinators. IWTS was also queried for CAS numbers to ensure any waste disposed was captured in the total amount reported. Negative values calculated are results of "found" inventory that was previously reported as used.

This methodology aligns with the default methodology presented in the TSD. INL relied on information contained in the Comply Plus inventory database and on hard copy maintenance records for HVAC systems and vehicles. The amounts of fluorinated gases emitted were calculated as detailed in examples in the TSD (depending on the original units of the gas included in the database or on the maintenance record).

\subsubsection{Results Discussion}

Using the method described above, the fugitive refrigerant emissions in Table 6 were considered for their contribution to INL's GHG emissions during FY12. A majority of the gases in the table evaluated were not considered to have any releases during FY12, but they are listed in the table to show that they have been evaluated. Also shown in the table is the GWP of each gas, which indicates each gas heat-trapping impact relative to $\mathrm{CO}_{2}$.

Table 6. Fugitive refrigerants evaluated for GHG emissions during FY12 at INL.

\begin{tabular}{|c|c|c|c|c|c|}
\hline \multirow[b]{2}{*}{ Common Name } & \multirow[b]{2}{*}{ GWP } & \multicolumn{2}{|c|}{ BEA 2012 CEDR } & \multicolumn{2}{|c|}{ FY12 TSD } \\
\hline & & $\begin{array}{c}\text { Mass } \\
\text { Emitted } \\
(\mathrm{lbs})\end{array}$ & $\begin{array}{c}\mathrm{GHG} \\
\text { Emissions } \\
\left(\mathrm{MT} \mathrm{CO}_{2} \mathrm{e}\right)\end{array}$ & $\begin{array}{c}\text { Mass Emitted } \\
\text { (lbs) }\end{array}$ & $\begin{array}{l}\text { GHG Emissions } \\
\quad\left(\mathrm{MT} \mathrm{CO}_{2} \mathrm{e}\right)\end{array}$ \\
\hline $\mathrm{CO}_{2}$ & 1 & 206.23 & 0.09 & 3.22 & 0.0 \\
\hline $\mathrm{CH}_{4}$ & 21 & $32,857.29$ & 312.98 & -588.29 & -5.6 .0 \\
\hline $\mathrm{N}_{2} \mathrm{O}$ & 310 & 0.12 & 0.02 & 0.0 & 0.0 \\
\hline HFC-23 & 11,700 & 1.31 & 6.95 & 0.0 & 0.0 \\
\hline HFC-32 & 650 & 139.2 & 41.04 & 180.5 & 53.22 \\
\hline HFC-41 & 150 & 0.06 & 0.00 & 0.0 & 0.0 \\
\hline HFC-125 & 2,800 & 150.56 & 191.22 & 60.12 & 76.35 \\
\hline HFC-134 & 1,000 & 0.0 & 0.0 & 0.0 & 0.0 \\
\hline HFC-134a & 1,300 & 374.02 & 220.55 & 419.61 & 247.44 \\
\hline HFC-143 & 300 & 0.0 & 0.0 & 0.0 & 0.0 \\
\hline HFC-143a & 3,800 & 12.48 & 21.51 & 20.76 & 35.78 \\
\hline
\end{tabular}


Table 6. (continued).

\begin{tabular}{|c|c|c|c|c|c|}
\hline \multirow[b]{2}{*}{ Common Name } & \multirow[b]{2}{*}{ GWP } & \multicolumn{2}{|c|}{ BEA 2012 CEDR } & \multicolumn{2}{|c|}{ FY12 TSD } \\
\hline & & $\begin{array}{c}\text { Mass } \\
\text { Emitted } \\
(\mathrm{lbs})\end{array}$ & $\begin{array}{c}\mathrm{GHG} \\
\text { Emissions } \\
\left(\mathrm{MT} \mathrm{CO}_{2} \mathrm{e}\right)\end{array}$ & $\begin{array}{c}\text { Mass Emitted } \\
\text { (lbs) }\end{array}$ & $\begin{array}{l}\text { GHG Emissions } \\
\quad\left(\mathrm{MT} \mathrm{CO}_{2} \mathrm{e}\right)\end{array}$ \\
\hline HFC-152 & 53 & 0.0 & 0.0 & 0.0 & 0.0 \\
\hline HFC-152a & 140 & 10.16 & 0.65 & 77.22 & 4.90 \\
\hline HFC-161 & 12 & 0.0 & 0.0 & 0.0 & 0.0 \\
\hline HFC-227ca & 2,900 & 0.0 & 0.0 & 0.0 & 0.0 \\
\hline HFC-227ea & 2,900 & 0.0 & 0.0 & 0.0 & 0.0 \\
\hline HFC-236ca & 120 & 0.0 & 0.0 & 0.0 & 0.0 \\
\hline HFC-236cb & 1,340 & 0.0 & 0.0 & 0.0 & 0.0 \\
\hline HFC-236ea & 1,370 & 0.0 & 0.0 & 0.0 & 0.0 \\
\hline HFC-236fa & 6,300 & 0.0 & 0.0 & 0.0 & 0.0 \\
\hline HFC-245ca & 560 & 0.0 & 0.0 & 0.0 & 0.0 \\
\hline HFC-245fa & 1,030 & 137.97 & 64.46 & 0.0 & 0.0 \\
\hline HFC-365mfc & 794 & 3.19 & 1.15 & 0.9 & 0.32 \\
\hline HFC-c-447-ef & 250 & $\mathrm{NE}$ & $\mathrm{NE}$ & $\mathrm{NE}$ & $\mathrm{NE}$ \\
\hline HFC-43-10mee & 1,300 & 1.23 & 0.73 & 0.0 & 0.0 \\
\hline PFC-14 & 6,500 & 0.0 & 0.0 & 0.0 & 0.0 \\
\hline PFC-116 & 9,200 & 0.0 & 0.0 & 0.0 & 0.0 \\
\hline PFC-218 & 7,000 & 2.18 & 6.92 & 1.1 & 3.5 \\
\hline $\begin{array}{l}\text { PFC-318 or } \\
\text { PFCc318 }\end{array}$ & 8,700 & 0.5 & 1.97 & 0.0 & 0.0 \\
\hline PFC-3-1-10 & 7,000 & 1.1 & 3.49 & 0.0 & 0.0 \\
\hline PFC-4-1-12 & 7,500 & 0.0 & 0.0 & 0.0 & 0.0 \\
\hline PFC-5-1-14 & 7,400 & 0.0 & 0.0 & 0.0 & 0.0 \\
\hline PFC-9-1-18 & 7,500 & 0.0 & 0.0 & 0.0 & 0.0 \\
\hline $\mathrm{c}-\mathrm{C}_{3} \mathrm{~F}_{6}$ & 17,340 & 0.0 & 0.0 & 0.0 & 0.0 \\
\hline $\begin{array}{l}\mathrm{SF}_{6}-\text { Sulfur } \\
\text { Hexafluoride }\end{array}$ & 23,900 & 6.0 & 65.05 & 6.0 & 65.05 \\
\hline $\mathrm{NF}_{3}$ & 17,200 & 0.0 & 0.0 & 0.0 & 0.0 \\
\hline & TOTAL & $33,903.6$ & 938.78 & 181.15 & 480.96 \\
\hline
\end{tabular}

As shown in Table 6, INL's fugitive emissions from refrigerants were calculated to produce $481 \mathrm{MT}$ $\mathrm{CO}_{2} \mathrm{e}$ in FY12. In FY12 this equates to $2.6 \%$ of INL's Scope 1 emissions, and a nearly negligible amount of the total anthropogenic emissions considered.

\subsubsection{Lessons Learned}

The accuracy of the data used to calculate GHG emissions from refrigerants are hard to verify as some of the maintenance records are completed by hand and stored in hard copy. It is difficult to be assured that all of the maintenance records have been reviewed, including fluorinated gas charges. There is some overlap in data contained on the maintenance records and Comply Plus. Comply Plus was used to verify the amounts of refrigerants emitted and the volumes reported on the maintenance records.

It may be helpful to have electronic data gathering at point of entry (i.e., maintenance personnel enter the data directly into an electronic system that updates to Comply Plus automatically, removing one 
potential source of error in data entry). Also, this would eliminate the requirement to obtain hard copies of the maintenance records and remove one source of information to review during the calculations.

\subsubsection{Comparison to FY08 Baseline}

INL's increase in FY12 over FY08 baseline is likely due to natural variations in fugitive purchasing cycles and improved data collection abilities and using the simplified mass balance approach for calculating release emissions.

Overall, although the variation between years is large, it is important to keep in mind the escalation of scale - overall fugitive emissions are a small contributor to the total INL GHG footprint. And although slight changes make for large changes within this emissions category, they are insignificant when compared to the total footprint.

It should be noted that INL's reporting is based on the DOE-HQ data calls for FY08 and FY12. The FY08 baseline asked about fewer items than the FY12 data call.

\subsubsection{Fugitive Emissions: Onsite Landfill}

INL utilized a combination of both an onsite and offsite (contracted) landfill for non-hazardous solid waste disposal during FY12. These Scope 1 calculations look at the emissions associated with solid waste disposal in the onsite landfill at the Central Facilities Area (CFA), while the Scope 3 calculations look at the emissions associated with contracted MSW disposal from town facilities that go to an offsite landfill.

INL operates the landfill at CFA, which accepts waste from all INL Site contractors. The CFA landfill currently includes one open designated area for compactable non-municipal solid waste that has been receiving waste since 1984. Three other designated waste areas have been opened and closed since 1947 and are no longer receiving waste. The CFA landfill has no landfill gas collection or destruction, is not subject to Title V GHG reporting, and has no formalized operating permit. ${ }^{\text {h }}$ A daily soil cover is applied to produce an estimated overall soil-to-trash ratio of one-to-one. Of the 198 acres currently designated as landfill space at CFA, 150 acres have been designated for compactable non-municipal solid waste, although only a portion of this area is currently being utilized. ${ }^{\mathrm{i}}$

\subsubsection{Calculation Method}

To determine the Scope 1 emissions associated with INL's onsite landfill, the historical quantities of solid waste were pulled from the INWMIS database. INWMIS tracks the amounts (by both weight and volume) and types of waste collected from each Site facility for delivery to the CFA landfill. INWMIS tracks multiple types of waste, including a number of types of construction and demolition waste. For this calculation, only two categories of waste in INWMIS were considered: Category 1 and 2 for "regular trash" and "cafeteria waste," respectively.

EPA's Landfill Gas Emissions Model (LandGEM) was used to calculate the GHG emissions associated with the CFA landfill, as identified in the TSD methodology. LandGEM utilizes the mass of solid waste disposed of from the year the landfill was opened until the year it was closed. The historical data shown in Table 7 were input to LandGEM to get the estimated annual amounts of $\mathrm{CO}_{2}$ (biogenic) and $\mathrm{CH}_{4}$ (anthropogenic) produced. These calculations only considered the open portion of the CFA landfill (open since 1984) and ignored the three areas that have been closed. Since INWMIS only includes data starting in 1992, the solid waste amounts for 1984 through 1991 were estimated based on an average trend from the available data (average of the previous 5 years). The solid waste disposed of in the CFA landfill is documented in Table 7.

\footnotetext{
h. INL's CFA landfill does not receive household waste, but it does receive a portion of waste that is MSW-like. It is operated according to a State of Idaho approved non-municipal solid waste operating plan which prohibits disposal of many substances including hazardous waste and sludge.

i. $\quad$ CFA landfill information is based on correspondence with Kathy Hernandez, email dated 29 January 2013.
} 
Table 7. Amount of solid waste produced annually since 1984 for disposal in INL's onsite CFA landfill.

\begin{tabular}{|c|c|}
\hline Fiscal Year & $\begin{array}{l}\text { Amount of Solid Waste } \\
\text { (tons) }\end{array}$ \\
\hline 1984 & $15,196.35$ \\
\hline 1985 & $15,196.35$ \\
\hline 1986 & $15,196.35$ \\
\hline 1987 & $15,196.35$ \\
\hline 1988 & $15,196.35$ \\
\hline 1989 & $15,196.35$ \\
\hline 1990 & $15,196.35$ \\
\hline 1991 & $15,196.35$ \\
\hline 1992 & $40,540.28$ \\
\hline 1993 & $8,308.58$ \\
\hline 1994 & $13,707.36$ \\
\hline 1995 & $9,178.26$ \\
\hline 1996 & $4,247.27$ \\
\hline 1997 & $1,436.32$ \\
\hline 1998 & $3,479.26$ \\
\hline 1999 & $1,135.21$ \\
\hline 2000 & $1,091.80$ \\
\hline 2001 & 972.30 \\
\hline 2002 & $1,099.19$ \\
\hline 2003 & $1,299.64$ \\
\hline 2004 & $1,639.89$ \\
\hline 2005 & $1,070.45$ \\
\hline 2006 & $1,754.07$ \\
\hline 2007 & $1,145.95$ \\
\hline 2008 & 826.64 \\
\hline 2009 & 647.06 \\
\hline 2010 & 805.48 \\
\hline 2011 & 708.65 \\
\hline 2012 & 663.54 \\
\hline TOTAL & $217,327.92$ \\
\hline
\end{tabular}

\subsubsection{Results Discussion}

INL's disposal of non-hazardous solid waste in the onsite landfill at CFA is estimated to conservatively contribute 5,617.1 $\mathrm{MT} \mathrm{CO}_{2} \mathrm{e}$ of anthropogenic emissions to the GHG inventory during FY12. An additional 815.5 $\mathrm{MT} \mathrm{CO}_{2} \mathrm{e}$ of biogenic emissions were contributed to the GHG inventory during FY12. In FY12, the anthropogenic emissions equate to 30.0\% of INL's Scope 1 emissions, and $6.4 \%$ of the total anthropogenic emissions considered. 


\subsubsection{Lessons Learned}

Since INL currently tracks the quantities and types of materials sent to the onsite landfill at CFA, the data used are considered accurate, and no changes are needed for streamlining the calculation in future years. However, additional searching may identify the amounts deposited in the landfill prior to 1992 , which had to be estimated for this calculation.

\subsubsection{Comparison to FY08 Baseline}

In FY12, there was a 5.8\% decrease over the FY08 GHG baseline. When considering the change in the amount (weight) of waste disposed per Site employee against the FY08 baseline, FY12 showed a $22.8 \%$ decrease.

In addition to EO 13514 setting GHG goals that led to INL quantifying their annual GHG emissions, the EO covers a number of other environmental areas including waste diversion. INL is currently working to divert their solid waste to meet a goal of $50 \%$ diversion by weight by 2015 ; this increased diversion rate is expected to result in a decrease in the overall amount of solid waste deposited in the landfill; however, it is not guaranteed since the diversion goal only considers the waste produced within a single year rather than compared to previous years.

It should be noted that the onsite landfill GHG calculations (the LandGEM) rely predominately on historical waste disposal amounts rather than current information, and there is a significant lag time before the current actions, particularly diversion efforts (i.e., recycling), will have a notable effect on the associated GHG emissions.

\subsubsection{Fugitive Emissions: Onsite Wastewater Treatment}

At its Site facilities, INL operates its own wastewater treatment, which consists of a combination of lagoons and septic systems. Evaporative lagoons are located at the major facilities, while septic tanks are located at the smaller or remote locations, including Experimental Breeder Reactor I, SMC fire station, the Gun Range, the main INL guard gate, and the Critical Infrastructure Test Range Complex (CITRC) (formerly known as the Special Power Excursion Test Reactor [SPERT] Tests II, III, and IV). It should be noted that the evaporative lagoons are facultative, with an aerobic upper layer and an anaerobic lower layer. The methodology behind the TSD considers facultative lagoons to be anaerobic.

INL also operates a number of lagoons (including evaporative ponds) for industrial waste. Since this industrial waste does not contain significant amounts of organics, the lagoons were not considered in these calculations.

\subsubsection{Calculation Method}

INL's data on onsite lagoons used for wastewater treatment are identified by facility in Table 8 for FY12. INL's Human Resources department provided the employee counts at each facility as an average for the year based on the numbers at the end of each quarter. The number of visitors to each facility was estimated based on $10 \%$ of the number of employees, a conservative estimate to account for subcontractors and visitors. 
Table 8 . FY12 population data by facility for onsite wastewater treatment calculations.

\begin{tabular}{|c|c|c|c|c|}
\hline Facility Name & Wastewater Type & $\begin{array}{l}\text { Number of } \\
\text { Employees }\end{array}$ & $\begin{array}{l}\text { Number of } \\
\text { Visitors }\end{array}$ & $\begin{array}{l}\text { Total Population } \\
\text { Considered }\end{array}$ \\
\hline EBR-I & Septic Tank & 1 & 0.1 & 1.1 \\
\hline CITRC & Septic Tank & 0.75 & 0.075 & 0.825 \\
\hline Gun Range & Septic Tank & 6.0 & 0.6 & 6.6 \\
\hline $\begin{array}{l}\text { Main INL Guard } \\
\text { Gate }\end{array}$ & Septic Tank & 2 & 0.2 & 2.2 \\
\hline \multicolumn{4}{|c|}{ TOTAL SEPTIC POPULATION } & 10.725 \\
\hline ATR & Lagoon & 503 & 50.3 & 553.3 \\
\hline CFA & Lagoon & 494 & 49.4 & 543.4 \\
\hline MFC & Lagoon & 879 & 87.9 & 966.9 \\
\hline SMC & Lagoon & 187 & 18.7 & 205.7 \\
\hline \multicolumn{4}{|c|}{ TOTAL LAGOON POPULATION } & $2,269.3$ \\
\hline
\end{tabular}

The population data Table 8 were used with the calculation method in the TSD, and the default national averages (from the TSD) for the specific treatment process.

\subsubsection{Results Discussion}

INL's onsite wastewater treatment is estimated to contribute $131.2 \mathrm{MT} \mathrm{CO}_{2} \mathrm{e}(130.6$ from lagoons and 0.6 from septic systems) emissions to the GHG inventory during FY12. In FY12 this equates to less than $1 \%$ of INL's Scope 1 emissions, and a nearly negligible amount of the total anthropogenic emissions considered.

\subsubsection{Lessons Learned}

For future inventories it is believed that site-specific data and the factors unique to INL would produce more accurate results than calculations based on national averages. In addition, future calculations for industrial waste treatment should be included, even though these are likely minimal GHG contributors relative to the lagoons.

\subsubsection{Comparison to FY08 Baseline}

In FY12, there was a 1.8\% increase over the FY08 GHG baseline. Since the wastewater calculations are based on employee counts, the increase in GHG emissions from wastewater generally followed the increase in employee numbers of $4.3 \%$ in FY12 over the FY08 baseline, indicating an approximate $2.5 \%$ reduction in water use per person.

\subsection{Scope Two - Indirect Emissions}

INL's FY12 Scope 2 emissions are summarized in Figure 8, with a comparison to the FY08 baseline shown in Figure 9. A discussion of INL's FY12 Scope 2 emissions categories follows, including the calculation methods, the significance of the results, lessons learned from the data collection and calculation process, and a comparison to the FY08 baseline results. A comprehensive table, as well as the FY08 baseline emissions and the subsequent FY data, is included in Appendix E, "Scope 2

Comprehensive Tables." 


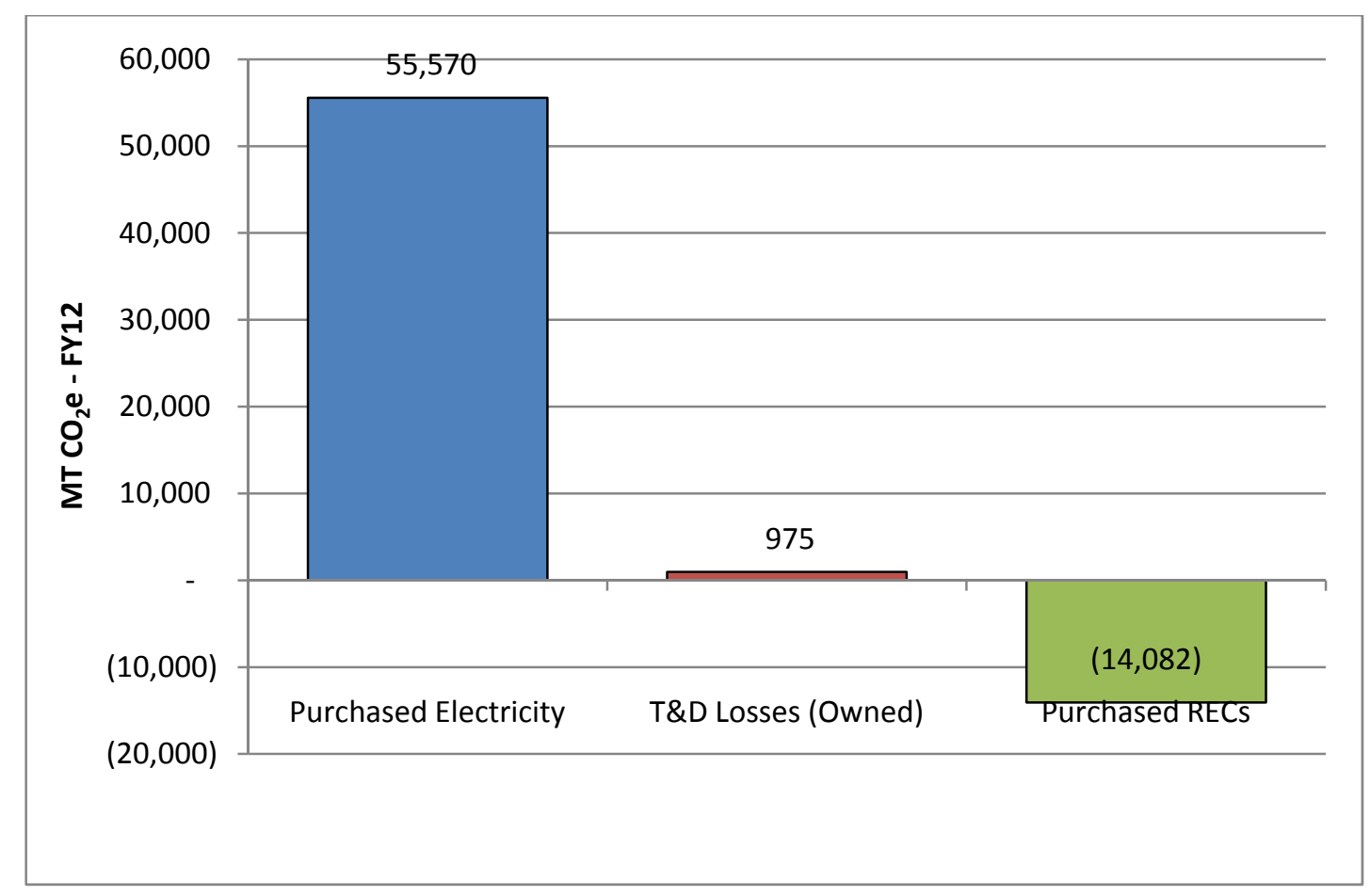

Figure 8. INL's FY12 GHG emission results for Scope 2.

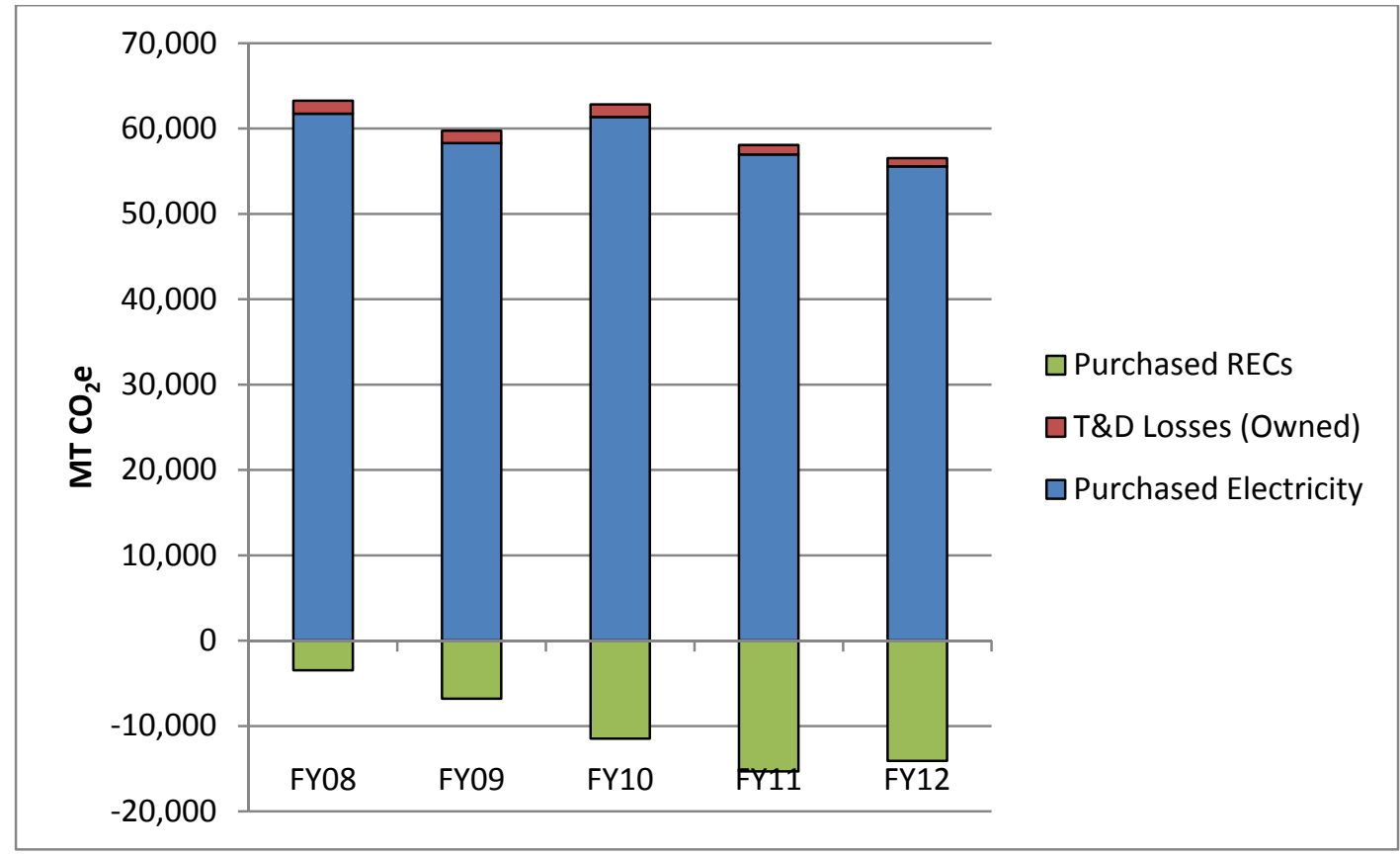

Figure 9. Comparison of INL's FY08, FY09, FY10, and FY12 Scope 2 GHG emissions. 


\subsubsection{Purchased Electricity Emissions}

\subsubsection{Calculation Method}

These calculations follow the TSD default methodology of electricity purchases reported for the CEDR. The amounts are determined based on a combination of monthly electrical bills and INL's onsite electricity meters. Since these data are also submitted in the CEDR and they are tracked for the INL Site, the only calculations needed were to isolate the emissions that INL owns (consumed in INL-operated facilities) from the other INL Site contractors.

INL purchases electricity from four different electrical utilities to support the operations of its different facilities: Idaho Falls Power supplies electricity to the town facilities, Idaho Power supplies electricity to the Site facilities as well as some small locations outside of Idaho Falls city limits, and Rocky Mountain Power and Lost River Electrical Company provide electricity to some of the smaller buildings and equipment outside of Idaho Falls city limits, including lighting at some bus lots. The breakdown in electrical purchases by electrical provider is shown in Table 9 for FY12.

INL purchased 148,785.07 MWh during FY12, with 34,143.26 MWh provided to non-Site locations, and 114,641.80 MWh going to INL facilities at the INL Site. Per the TSD, the emission factors for purchased electricity are determined using the EPA's Emissions \& Generation Resource Integrated Database (eGRID) and the location of INL's facilities. eGRID uses subregional emission factors based on plant-specific data in that region, as reported to the EPA, the Energy Information Administration (EIA), and the Federal Energy Regulatory Commission (FERC). (For more information on eGRID, refer to www.epa.gov/cleanenergy/energy-resources/egrid.) All INL facilities are located in the "Western Electricity Coordinating Council (WECC) Northwest" eGRID subregion, the Northwest Power Pool (NWPP).

Table 9. INL's FY12 electrical purchases by location and provider.

\begin{tabular}{|c|c|c|c|}
\hline Location & $\begin{array}{c}\text { Owner of } \\
\text { T\&D System }\end{array}$ & Electrical Provider & $\begin{array}{l}\text { FY12 Electricity } \\
\text { Purchase (MWh) }\end{array}$ \\
\hline INL Site & INL & $\begin{array}{l}\text { Idaho Power (includes owned } \\
\text { T\&D losses) }\end{array}$ & $114,641.80$ \\
\hline \multicolumn{3}{|r|}{ SUBTOTAL (Site) } & $114,641.80$ \\
\hline $\begin{array}{l}\text { Assorted Locations (excludes } \\
\text { INL Site) }\end{array}$ & $\begin{array}{l}\text { Electrical } \\
\text { Provider }\end{array}$ & Idaho Power & 73.17 \\
\hline Town Facilities & $\begin{array}{l}\text { Electrical } \\
\text { Provider }\end{array}$ & Idaho Falls Power & $33,883.35$ \\
\hline $\begin{array}{l}\text { Assorted Locations Outside INL } \\
\text { Site and Idaho Falls City Limits }\end{array}$ & $\begin{array}{l}\text { Electrical } \\
\text { Provider }\end{array}$ & Lost River Electric Company & 2.55 \\
\hline $\begin{array}{l}\text { Assorted Locations Outside INL } \\
\text { Site and Idaho Falls City Limits }\end{array}$ & $\begin{array}{l}\text { Electrical } \\
\text { Provider }\end{array}$ & Rocky Mountain Power & 184.19 \\
\hline \multicolumn{3}{|r|}{ SUBTOTAL (Non-Site) } & $34,143.26$ \\
\hline \multicolumn{3}{|r|}{ TOTAL INL Purchases } & $148,230.66$ \\
\hline
\end{tabular}

\subsubsection{Results Discussion}

For FY12, the purchased electricity and owned T\&D losses amount to 56,545.30 $\mathrm{MT} \mathrm{CO}_{2} \mathrm{e}$, which is all of INL's Scope 2 emissions (before accounting for the credit from the RECs) and $64.6 \%$ of the net total anthropogenic emissions considered. 


\subsubsection{Lessons Learned}

Since these data are already collected and reported annually for the CEDR, they are considered to be of high quality.

\subsubsection{Comparison to FY08 Baseline}

In FY12, INL purchased 4.0\% less electricity than the FY08 baseline, which yielded a $10.0 \%$ decrease in associated GHG emissions.

Efforts to reduce the overall INL carbon footprint will focus on reducing electricity demand since this source is such a significant contributor.

\subsubsection{Transmission and Distribution Loss Emissions, Owned}

\subsubsection{Calculation Method}

The TSD calls for differentiating between T\&D losses within INL's operational controls and those outside INL's operational controls as Scope 2 and 3, respectively, based on whether the organization owns the associated transmission lines. To facilitate this differentiation, electricity purchases in Table 9 are identified according to who owns the T\&D system: INL or the electrical provider. Since INL owns the electrical grid at the Site, and the T\&D losses are considered within INL's operational controls, the electricity purchase for the Site from Idaho Power (shown in Table 10) includes the associated T\&D losses. (The Scope 3 T\&D losses [outside INL's operational controls] are based on the total INL electrical purchase.)

The amount of INL's owned T\&D losses was calculated based on an average T\&D loss factor of $2.278 \%$ in FY12. This percentage was determined based on the difference between the total amount of electricity purchased for the INL Site (based on the Idaho Power meter at the Scoville, Idaho substation) and the total metered amounts at individual Site facilities (this difference accounts for the losses within the INL Site).

\subsubsection{Results Discussion}

The owned T\&D losses of 2,611.54 MWh for FY12 equates to 975.39 $\mathrm{MT} \mathrm{CO}_{2} \mathrm{e}$ of emissions. It should be noted that this T\&D loss is already accounted for in the purchased electricity emissions, and simply reduces the GHG emissions from purchased electricity report above; the goal of these calculations was to isolate this amount for reporting purposes according to the TSD.

\subsubsection{Lessons Learned}

Since this calculation is based on a percentage of the GHG emissions presented for INL's Scope 2 electricity purchases, the data used are considered accurate, and no changes are needed for streamlining the calculation in future years.

\subsubsection{Comparison to FY08 Baseline}

Since T\&D losses are based on a percentage of the INL electricity purchase, a comparison to the FY08 baseline yields the same results as Section 4.3.1.4.

\subsubsection{Renewable Energy Certificates Emissions}

\subsubsection{Calculation Method}

In addition to the electricity purchased directly for its facilities, INL purchased the following amount of RECs to offset a portion of its carbon emissions:

- 22,000 MWh in FY12 from multiple wind power projects in Washington, Oregon, and Wyoming. (See Appendix F, "Receipt for RECs Purchased in FY12," for the receipt, which includes details on INL's RECs purchase.) 
INL did not actually purchase renewable energy, but rather purchased the RECs or certified environmental benefits of the renewable energy generated in another region to support the growth and expansion of the renewable energy industry as a whole. INL is credited for the GHG emissions that this renewable energy did not emit.

The emission factors for the RECs purchased in FY12 are based on the wind power facility locations in Washington, Oregon, and Wyoming, and the "Northwest Power Pool (NWPP) of the Western Electricity Coordinating Council (WECC)" eGRID subregion (the subregion was determined using the facility's ZIP Codes and EPA's Power Profiler Web site [www.epa.gov/cleanenergy/energy-resources/egrid]). (Note that the TSD calls for using the eGRID non-baseload emission rates for calculating the GHG emissions associated with RECs, as opposed to the baseload emission rates used for emissions from purchased electricity.)

\subsubsection{Results Discussion}

Table 10 summarizes how much INL reduced its Scope 2 GHG emissions in FY12 by purchasing RECs. Specifically, the RECs purchases decreased the overall Scope 2 GHG emissions by 14,082 MT $\mathrm{CO}_{2} \mathrm{e}$ in FY12.

Table 10. INL's GHG emissions from electricity and RECs purchased in FY12.

\begin{tabular}{|r|c|}
\hline \multicolumn{1}{|c|}{ Emissions Category } & $\begin{array}{c}\text { FY12 GHG Emissions } \\
\left(\mathrm{MT} \mathrm{CO}_{2} \mathrm{e}\right)\end{array}$ \\
\hline $\begin{array}{l}\text { Purchased Electricity (includes T\&D losses within INL's } \\
\text { operational controls) }\end{array}$ & $56,545.30$ \\
\hline Purchased RECs (displaced GHG emissions) & $(14,082.27)$ \\
\hline \multicolumn{2}{|r|}{ SCOPE 2 TOTAL } \\
\hline
\end{tabular}

\subsubsection{Lessons Learned}

Since these data are based on the RECs receipts, and are already collected and reported annually for the CEDR, they are considered to be of high quality.

\subsubsection{Comparison to FY08 Baseline}

In FY12, significantly more (233\% more) RECs were purchased than FY08 (by MWh). The associated emissions avoided were calculated according to the NWPP subregional eGRID emission factors, which led to a $305 \%$ increase over FY08.

\subsection{Scope Three - Indirect Emissions}

INL's FY12 Scope 3 emissions are summarized in Figure 10, with a comparison to the FY08 baseline shown in Figure 11. Each of the Scope 3 emissions categories is discussed here and includes the calculation methods, the significance of the results, lessons learned from the data collection and calculation process, and a comparison to the FY08 baseline results. A comprehensive table, as well as the FY08 baseline emissions and the subsequent FY data, is included in Appendix G, "Scope 3

Comprehensive Tables." 


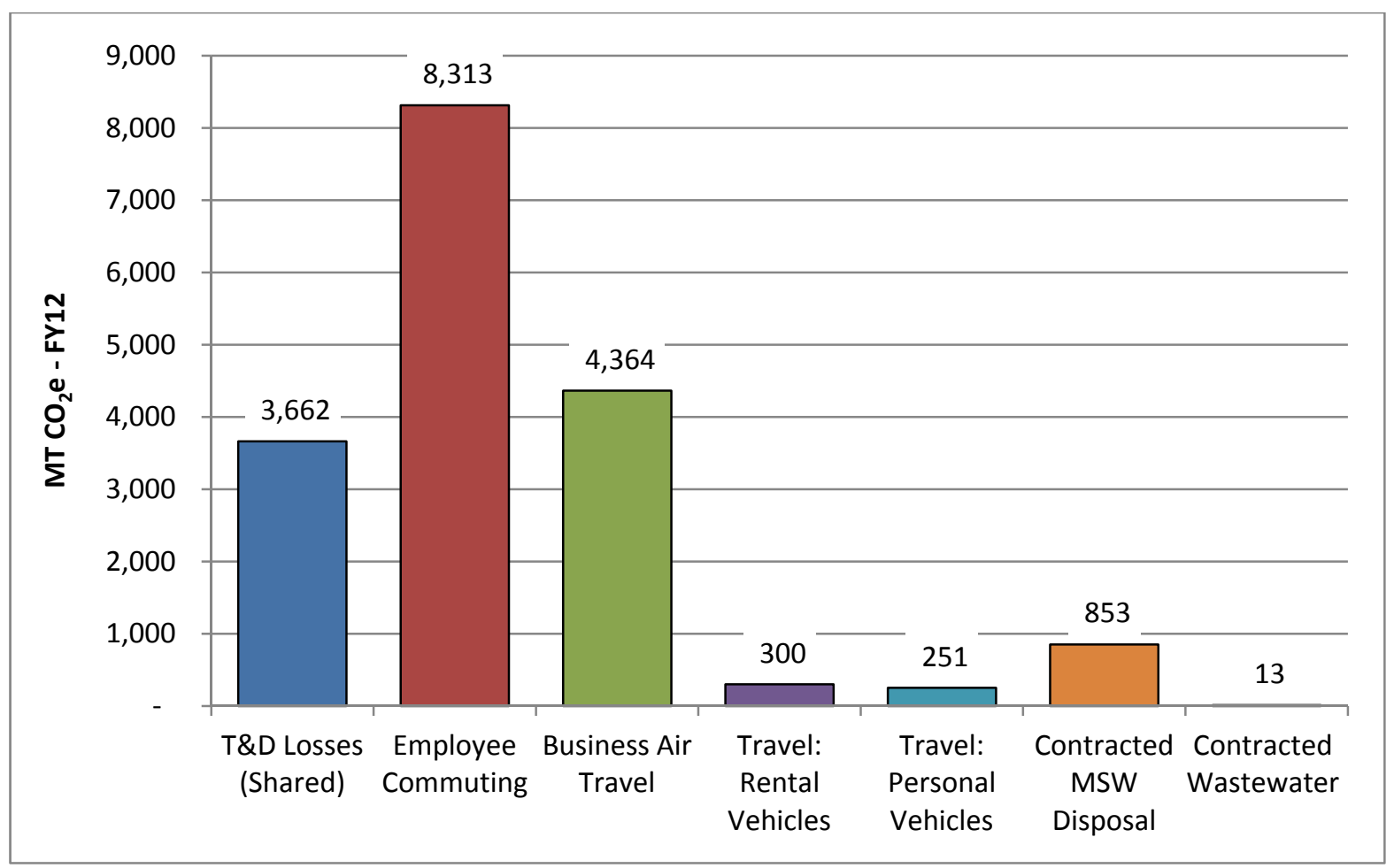

Figure 10. INL's FY12 GHG emission results for Scope 3.

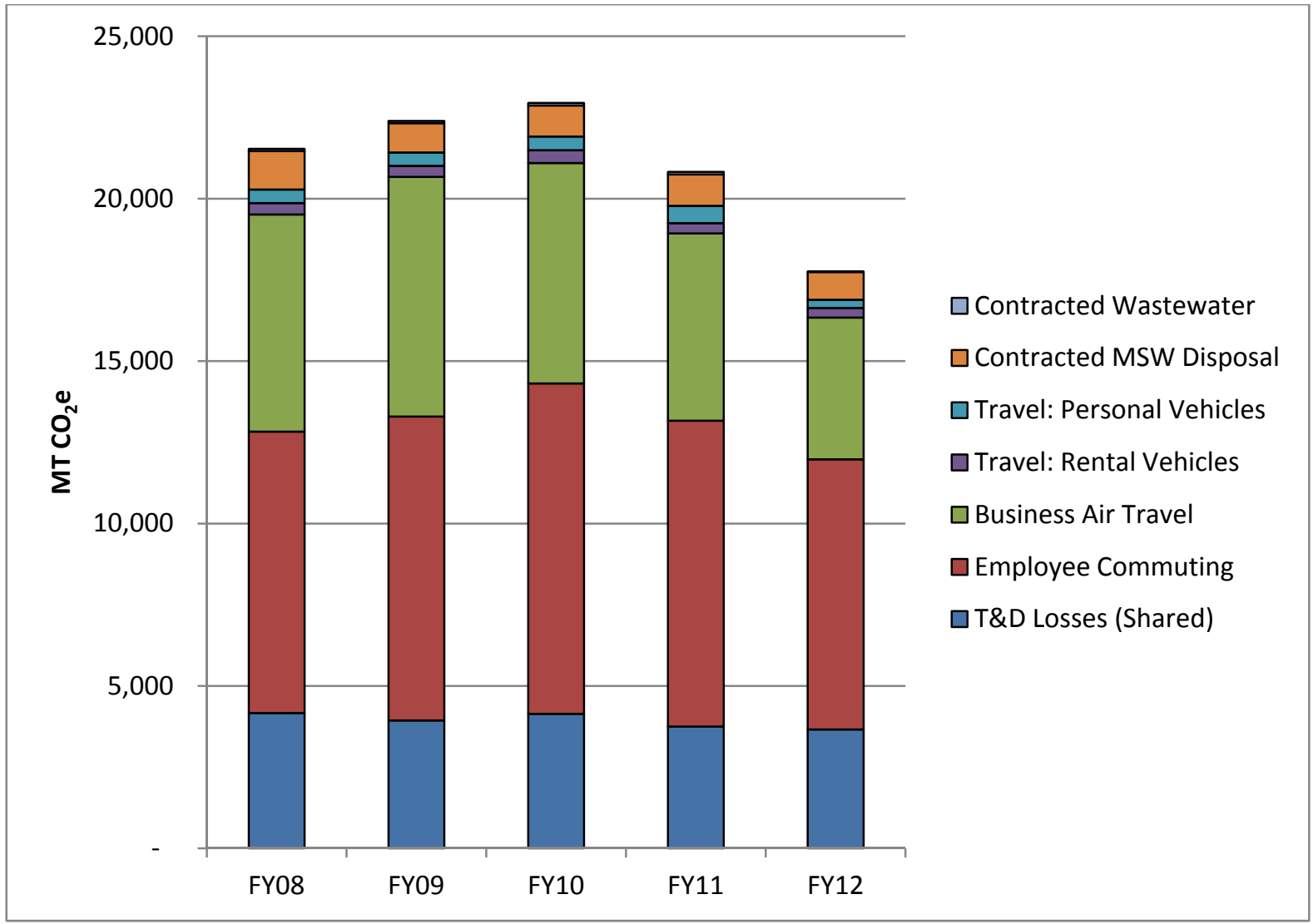

Figure 11. Comparison of INL's FY08, FY09, FY10, FY11, and FY12 Scope 3 GHG emissions. 


\subsubsection{Transmission and Distribution Loss Emissions, Shared}

\subsubsection{Calculation Method}

The TSD provides only a default calculation methodology for determining the GHG emissions from T\&D losses outside INL's operational control. This method assumes the national average T\&D loss factor of $6.59 \%$ for purchased electricity, and utilizes the same eGRID subregion emission factors used for Scope 2 purchased electricity (www.epa.gov/cleanenergy/energy-resources/egrid). As stated in Section 4.3.1.1, the TSD differentiates between T\&D losses inside and outside of INL's operational controls. While the owned T\&D losses reported in Scope 2 are based only on the electricity purchase at the Site where INL owns the T\&D lines, the Scope 3 shared T\&D losses are based on INL's total annual electrical purchase.

\subsubsection{Results Discussion}

A T\&D loss of $6.59 \%$ equates to 9,804.94MWh for INL's FY12 electricity purchases, and 3,662.06 $\mathrm{MT} \mathrm{CO}_{2} \mathrm{e}$ of emissions. In FY12 this equates to 20.6\% of INL's Scope 3 emissions, and 4.2\% of the total anthropogenic emissions considered.

\subsubsection{Lessons Learned}

Since this calculation is based on a percentage of the GHG emissions presented for INL's Scope 2 electricity purchases, the data used are considered accurate, and no changes are needed for streamlining the calculation in future years.

\subsubsection{Comparison to FY08 Baseline}

Since T\&D losses are based on a percentage of the INL electricity purchase, a comparison to the FY08 baseline yields the same results as Section 4.3.1.4.

\subsubsection{Employee Commuting Emissions}

\subsubsection{Calculation Method}

The TSD identified an employee survey as the best source for calculating the GHG emissions from employee commuting. Employee commuting behaviors for FY08 and FY09 were calculated by utilizing available historical data that was gathered and combined with appropriate assumptions for FY08 and FY09 calculation. However, for the FY12 calculation of employee commuting emissions, a survey was utilized. These processes are described below.

The FY12 employee commute survey was distributed to 4,153 employees. The distribution list included subcontractors with INL e-mail addresses (since they were assumed to be dedicated INL employees with offices within INL offices), but did not include management at the director level and above. The survey response was approximately 53\% (2,209 employees completed the survey) and considered to be representative of the INL population. The results were distributed across the total INL FY12 population, which included subcontractors. The survey results are summarized in a report, as well as several Excel spreadsheets.

\subsubsection{Results Discussion}

As shown in Table 11, INL employees commuted an estimated 19.6 million vehicle-miles during FY12. The associated GHG emissions were estimated to be 8,313.16 $\mathrm{MT} \mathrm{CO}_{2} \mathrm{e}$. In FY12, the GHG emissions equates to $46.8 \%$ of INL's Scope 3 emissions, and $9.5 \%$ of the total anthropogenic emissions. 
Table 11. Number and type of commute miles traveled by INL employees during FY12.

\begin{tabular}{|l|r|r|}
\hline \multicolumn{1}{|c|}{ Type of Miles } & Number of Miles & $\begin{array}{c}\text { GHG Emissions } \\
\left(\mathrm{MT} \mathrm{CO}_{2} \mathrm{e}\right)\end{array}$ \\
\hline Passenger Car Miles, Gasoline & $12,191,061.62$ & $4,566.42$ \\
\hline Passenger SUV or Truck Miles, Gasoline & $5,790,039.03$ & $3,093.77$ \\
\hline Motorcycle Miles & $141,226.58$ & 24.10 \\
\hline Passenger Car Miles, Diesel & $227,665.87$ & 102.92 \\
\hline Passenger SUV or Truck Miles, Diesel & $772,147.64$ & 433.52 \\
\hline Passenger Car Miles, Alternative Fuel & $489,078.99$ & 92.44 \\
\hline TOTAL VEHICLE MILES & $19,611,219.73$ & $8,313.16$ \\
\hline Walk, Run, or Bike Miles & $84,320.40$ & 0 \\
\hline TOTAL COMMUTE MILES & $19,695,540.14$ & $8,313.16$ \\
\hline
\end{tabular}

\subsubsection{Lessons Learned}

With a commute survey response of $53 \%$, it may be more beneficial to send the survey out earlier in the year. At the time the survey was launched there were several major changes occurring regarding employee commuting: a voluntary separation program was underway and completed, and the bus system notified employees of changes to bus pass pricing and continued to eliminate Idaho Falls local neighborhood bus routes and replaced them with Idaho Falls Park and Ride locations, which may have impacted how and if employees decided to participate in the survey.

\subsubsection{Comparison to FY08 Baseline}

In FY12, there was a $4.3 \%$ decrease in GHG emissions from employee commuting over the FY08 baseline. Although there was a slight increase in number of employees, the number of commute miles per employee decreased $7.2 \%$.

The commute survey utilized in FY12, to gather the commute data, could be considered more accurate than the method used in FY08, which called for a great number of assumptions.

\subsubsection{Business Air Travel Emissions}

INL employees took 8,665 business trips during FY12, as indicated by submitted and approved travel request forms. Employees submit the forms to the INL Travel Office to make necessary reservations for both domestic and international travel on behalf of the Laboratory. Travel request forms are also submitted to secure insurance coverage for employees that do not need travel arrangements, so there are times when a form is submitted and no travel arrangements are necessary (this could lead to no Scope 3 GHG emissions calculated, for example, in the case where an employee uses an INL fleet vehicle or is carpooling in another employee's personal vehicle to an offsite location).

Each trip can include commercial airline and/or ground travel (in both personal and rental cars). Ground travel by taxi, bus, or rail is less common and is currently only tracked as a dollar value when an employee requests reimbursement. For the FY12 GHG calculations, only employees travelling by commercial airline, personal vehicle, and rental vehicle were included. Travel by taxi, bus, rail, and other commercial means is not currently tracked; furthermore, they are considered de minimis when compared to these other transportation means, especially airline travel. It is also considered likely that INL travelers with large ground transportation needs will rent a car, rather than take public transportation; thus, these emissions are included in INL's FY12 inventory. 
INL travel requests are submitted by full-time INL employees as well as by subcontractors, student interns, and prospective employees traveling for interviews, house-hunting, and/or relocation. If an employee is performing work for others, their trip may be paid for and arranged by the external entity, and thus these data would not be tracked by the INL Travel Office nor included in the reported airline miles. This would also apply to tracking the associated personal and rental car miles. In these cases, the "other" would own the associated GHG emissions.

\subsubsection{Calculation Method}

The TSD provides one calculation method (the default methodology) for calculating the GHGs of airline travel, which is based on the actual flight miles traveled. This data was provided by the travel vendor as total passenger-miles traveled on short, medium, and long-haul flights ${ }^{j}$ based on the length of each individual flight leg of an employee's trip (as opposed to the total miles between the starting and destination airports). These passenger-miles were then multiplied by the appropriate emission factors for short, medium, and long-haul flights that account for the increased GHG emissions during take-off and landing. (This is different from the FY08 calculation approach when the travel vendor was only able to provide a value for the total passenger-miles traveled, and then it was multiplied by an average emission factor per mile of commercial flight.)

\subsubsection{Results Discussion}

Table 12 shows that the 22,085,517 passenger-miles flown by INL employees during FY12 resulted in an estimated 4,364.11 MT CO 2 e, or $0.198 \mathrm{MT} \mathrm{CO}_{2} \mathrm{e}$ per 1,000 passenger-miles for the year. In FY12, this equates to $24.6 \%$ of INL's Scope 3 emissions, and $5.0 \%$ of the total anthropogenic emissions considered.

Table 12. Number of miles flown by INL employees during FY12.

\begin{tabular}{|c|c|c|}
\hline \multirow[b]{2}{*}{ Type of Miles } & \multicolumn{2}{|c|}{ FY12 } \\
\hline & $\begin{array}{c}\text { Number of } \\
\text { Passenger-Miles }\end{array}$ & $\begin{array}{c}\text { GHG Emissions } \\
\left(\mathrm{MT} \mathrm{CO}_{2} \mathrm{e}\right)\end{array}$ \\
\hline Short Haul & $2,331,351$ & 653.13 \\
\hline Medium Haul & $3,482,410$ & 581.73 \\
\hline Long Haul & $16,371,756$ & $3,129.25$ \\
\hline TOTAL & $22,085,517$ & $4,364.11$ \\
\hline
\end{tabular}

\subsubsection{Lessons Learned}

Since this data is already tracked, it is considered accurate and no changes are needed for future reporting.

\subsubsection{Comparison to FY08 Baseline}

When comparing the FY12 inventory to the FY08 GHG baseline, there was a $14.5 \%$ decrease in airline GHG emissions, 9.6\% fewer passenger-miles flown, and an overall $20.9 \%$ decrease in the number of trips ${ }^{\mathrm{k}}$ per employee.

INL employees are traveling less; however, they are flying more domestic miles. It should be noted that the FY08 passenger-miles were not able to be broken down into flight length, which resulted in using

j. Short haul are flight segments $<300$ miles, medium haul are flight segments 300-699 miles, and long haul are flight segments $>700$ miles.

k. The number of trips includes all of the trips coordinated by the INL Travel Office, and includes more than airline trips. 
an emissions factor for unknown flight lengths that appears to have been more conservative than using emission factors specific to the flight segment length.

\subsubsection{Business Ground Travel: Rental Vehicle Emissions}

\subsubsection{Calculation Method}

For calculating the GHG emissions from rental vehicles, the INL Travel Office was able to provide the total number of miles that INL employees traveled during FY12 by each vehicle class. This data was provided by the rental car vendor.

Vehicle classes were divided into two categories: passenger cars and light-duty trucks/vans/SUVs. The emission factors from the TSD were applied accordingly based on these two categories.

This calculation process followed the TSD's advanced methodology since the number of miles traveled in each rental car class was known (the default methodology called for making assumptions on the numbers of vehicle miles per rental car use).

\subsubsection{Results Discussion}

As shown in Table 13, INL's rental car use during FY12 resulted in $299.78 \mathrm{MT} \mathrm{CO}_{2} \mathrm{e}$ based on 704,225 vehicle-miles traveled this year. In FY12 this equates to 1.7\% of INL's Scope 3 emissions, and a nearly negligible amount of the total anthropogenic emissions considered.

Table 13. Number of vehicle-miles traveled in rental cars by INL employees during FY12.

\begin{tabular}{|r|c|c|}
\hline \multirow{2}{*}{\multicolumn{2}{|c|}{ Vehicle Class }} & \multicolumn{2}{|c|}{ FY12 } \\
\cline { 2 - 3 } & $\begin{array}{c}\text { Number of } \\
\text { Vehicle Miles }\end{array}$ & $\begin{array}{c}\text { GHG Emissions } \\
\left(\mathrm{MT} \mathrm{CO}_{2} \mathrm{e}\right)\end{array}$ \\
\hline Passenger Cars & 478,904 & 179.38 \\
\hline Light-Duty Truck/Van/SUV & 225,320 & 120.39 \\
\hline TOTAL & 704,225 & 299.78 \\
\hline
\end{tabular}

\subsubsection{Lessons Learned}

Since the number of miles traveled in rental vehicles is already tracked by the rental car vendors, these data are considered to be of high quality, and no changes are needed for tracking the data in future years.

\subsubsection{Comparison to FY08 Baseline}

In FY12, there was a $14.5 \%$ decrease in GHG emissions from rental vehicle business travel over the FY08 baseline, while the number of miles traveled decreased by $12.6 \%$.

\subsubsection{Business Ground Travel: Personal Vehicle Emissions}

\subsubsection{Calculation Method}

For calculating the GHG emissions from personal vehicles, the INL Travel Office was able to provide the total number of miles that INL employees traveled during FY12 in personal vehicles as submitted in electronic expense reports for reimbursement. The expense report programmer provided this data to the INL Travel Office.

To determine which emission factors to use for calculating the associated GHG emissions during FY12, the distribution between passenger cars and light-duty trucks/vans/SUVs that was found in the FY12 employee commute survey was used (this amounted to $66 \%$ of the travel completed in passenger cars and $34 \%$ in light-duty trucks/vans/SUVs). 


\subsubsection{Results Discussion}

The 586,038 vehicle-miles that INL employees traveled during FY12 resulted in an estimated 251.34 MT $\mathrm{CO}_{2}$ e. In FY12 this equates to 1.4\% of INL's Scope 3 emissions, and a nearly negligible amount of the total anthropogenic emissions considered.

\subsubsection{Lessons Learned}

The electronic system for expense reports that was introduced during FY10 will continue to allow for more streamlined and accurate reporting of personal car miles than previous years (FY08 and FY09) when a representative sample was used. An additional assumption could be removed in future years if employees were asked to indicate the type of vehicle they used for their personal vehicle miles during the reimbursement process (since the actual distribution between the type of vehicles traveled was not known, an assumption was made based on the commute survey responses).

\subsubsection{Comparison to FY08 Baseline}

In FY12, there was a 39.1\% decrease in GHG emissions from personal vehicle business travel over the FY08 baseline, while the number of miles traveled also decreased by $39.3 \%$.

\subsubsection{Contracted MSW Disposal Emissions}

\subsubsection{Calculation Method}

To determine the Scope 3 emissions associated with INL's contracted offsite waste disposal from town facilities during FY12, the quantity of MSW sent to an offsite landfill was compiled. This information came from the City of Idaho Falls invoice records of the trash-collection history for each town building, including dumpster location, size of dumpster, and pick-up frequency.

Since the City of Idaho Falls does not track actual volumes or weights of solid waste collected from INL facilities, the records of dumpster size and pick-up frequency from monthly invoices were used to calculate an estimated volume (assuming dumpster fill rates of $80 \%$ ). The FY12 volume of 8,822 cubic yards, was converted to a weight based on an assumed solid waste density of 150 pounds per cubic yard (density value was selected based on EPA range

[www.epa.gov/epawaste/conserve/tools/recmeas/docs/guide b.pdf]). This resulted in a weight of 661.68 tons $(1,323,360$ pounds) for INL's offsite MSW disposal during FY12.

The TSD default methodology identifies the EPA's municipal solid waste mass balance model to calculate the GHG emissions associated with offsite MSW disposal. The estimated weight of INL's MSW disposed offsite was used with the calculation method in the TSD, along with default national averages (from the TSD).

\subsubsection{Results Discussion}

INL's offsite disposal of MSW during FY12 is estimated to contribute $852.97 \mathrm{MT} \mathrm{CO}_{2} \mathrm{e}$ to FY12's anthropogenic GHG inventory. In FY12, this equates to 4.8\% of INL's Scope 3 emissions, and 1.0\% of the total anthropogenic emissions considered.

It was also calculated that $111.7 \mathrm{MT} \mathrm{CO}_{2} \mathrm{e}$ of biogenic emissions were released in FY12.

\subsubsection{Lessons Learned}

Since the quantity of INL's MSW sent for offsite disposal is based on estimated volumes and an assumed density, it would be preferable to work with the City of Idaho Falls to get actual weights collected. If actual weights are not available, then actual volumes could be collected, and a sample of INL's MSW could be analyzed to determine an INL-specific density. These approaches will also assist with more accurate tracking of INL's waste disposal and overall diversion rates that are additional requirements under EO 13514. 
In addition to the waste volumes estimated from the city, INL has several small buildings located outside of Idaho Falls city limits that were not included in the amount of MSW collected from INL for offsite disposal. In future years it would be good to include these amounts.

\subsubsection{Comparison to FY08 Baseline}

In FY12, there was a $28.1 \%$ decrease over the FY08 baseline. When considering the change in waste disposed per employee against the FY08 baseline, FY12 showed a 33.4\% decrease. These decreases are likely due to the change in recycling practices at INL site and town facilities, which allows for a greater number of items to be recycled.

As discussed previously for the onsite landfill baseline comparison, Section 4.2.4.4, the EO 13514 waste diversion goals are expected to decrease INL's amount of GHGs produced by contracted MSW disposal.

\subsubsection{Contracted Wastewater Treatment}

\subsubsection{Calculation Method}

Wastewater from INL's town facilities is sent for treatment to the City of Idaho Falls' wastewater treatment plant and is INL's only source of offsite contracted treatment.

Employee counts at INL's town facilities was provided by Human Resources as an average during FY12, based on the total number of employees at the end of each quarter of the year. The reported number of town employees was 1,942 employees for FY12. The number of visitors to the town facilities was estimated based on $10 \%$ of the number of employees. This yielded a total population of 2,136.2, which was used with the calculation method in the TSD along with default national averages (from the TSD) for the specific treatment process.

\subsubsection{Results Discussion}

INL's contracted wastewater treatment during FY12 is estimated to contribute $13.2 \mathrm{MT} \mathrm{CO}_{2} \mathrm{e}^{1}$ emissions to the GHG inventory. In FY12, this equates to less than $0.1 \%$ of INL's Scope 3 emissions, and a nearly negligible amount of the total anthropogenic emissions considered.

\subsubsection{Lessons Learned}

For future inventories it is believed that site-specific data and factors would produce more accurate results than calculations based on national averages.

\subsubsection{Comparison to FY08 Baseline}

In FY12, there was a 7.9\% increase over the FY08 GHG baseline. Since the wastewater calculations are based on employee counts, the increase in GHG emissions from wastewater directly followed the increase in INL's total town employee counts of 7.9\% in FY12 over the FY08 baseline.

1. It should be noted that during the FY12 calculations, it was discovered that an incorrect equation was used for FY08 and subsequent years. The TSD directions indicated the reporting portal would automatically calculate emissions from flaring. This was missed in previous years. For FY08 \% comparisons, the FY08 data was revised for a total emissions from contracted wastewater treatment of $12.25 \mathrm{MT} \mathrm{CO}_{2} \mathrm{e}$, resulting in a 7.9\% increase for $\mathrm{FY} 12$ for both population change and for GHG emissions. ("Offsite Wastewater (FY08)" tab in "FY12 Wastewater for GHG (Scope 1+3) 9Oct12.xlsx") 


\section{PUTTING INL'S FOOTPRINT INTO PERSPECTIVE}

During FY12, the INL GHG inventory is estimated to have emitted 78,965 MT of anthropogenic $\mathrm{CO}_{2} \mathrm{e}$. This represents 19.3 MT for each employee working at INL that year. Furthermore, the total GHG emissions generated by the Laboratory during FY12 are the equivalent to the $\mathrm{CO}_{2}$ emissions from any one of the following ${ }^{\mathrm{m}}$ :

- Consuming almost 8.9 million gallons of gasoline or more than 183,639 barrels of oil

- Driving 16,451 passenger vehicles for a year

- Supplying electricity to 11,821 homes for a year.

Comparing these equivalency results to the FY08 baseline shows that INL removed an equivalent of 5,692 vehicles from the road in FY12. As an overall reduction goal, INL has met the EO 13514 total emissions goals for FY20. The FY20 target goal for INL is 87,039 MT of anthropogenic $\mathrm{CO}_{2} \mathrm{e}$. INL has surpassed this overall reduction goal by over $8,000 \mathrm{MT} \mathrm{CO}_{2} \mathrm{e}$.

m. Calculated with the EPA Greenhouse Gas Equivalencies (www.epa.gov/cleanenergy/energy-resources/calculator.html) in February 2013. 


\section{SUMMARY AND CONCLUSIONS}

Executive Order 13514 mandates reductions in the output of GHGs generated by federal agencies. These reductions are targeted at 28\% for direct (Scope 1 and 2) emissions and $13 \%$ for indirect (Scope 3 ) emissions, all by 2020 (White House 2010a and b). The EO set 2008 as the baseline year against which reductions will be measured, and this report documents the calculations for INL's FY12 inventory and the associated reductions. The reductions observed in GHG emissions are shown in Figure 12 along with the 2020 goal. The specific values in FY12 consist of a 33\% reduction for Scope 1 and 2, and a 17.5\% decrease for Scope 3 was calculated over the respective FY08 baseline values.

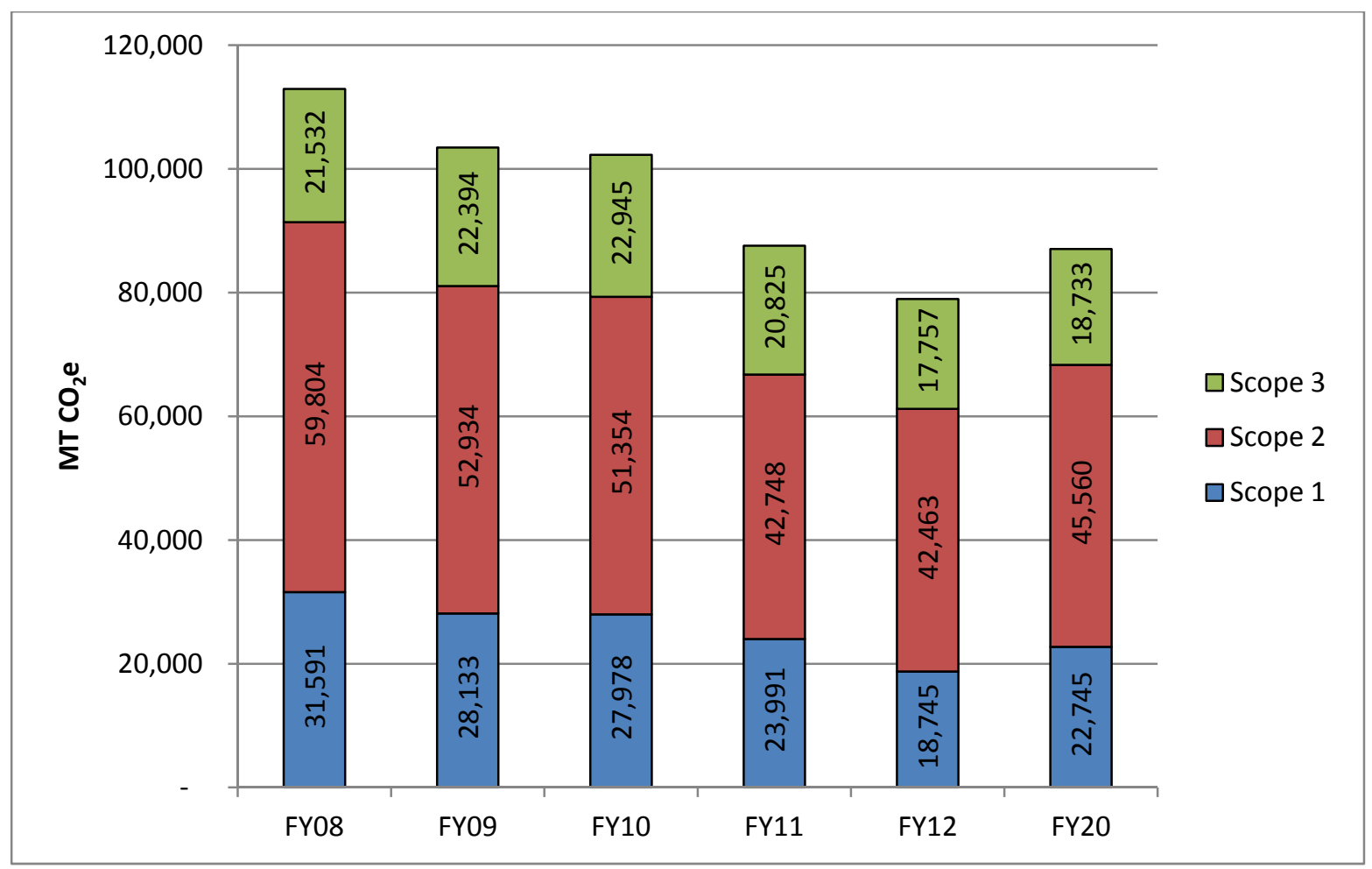

Figure 12. Comparison of INL's FY08, FY09, FY10, FY11, and FY12 actual, and FY20 goal GHG emissions, by scope.

While preparing this inventory, it was observed that much of the data needed to quantify INL's GHG emissions already exist in high quality form, since they are recorded and tracked for reports to other federal entities. Some information is less accessible, but can be approximated from existing records and will be better tracked in the future due to the standards established by INL in response to the EO and the Laboratory's concern for the environment. Some data and assumptions must be estimated using national averages supplied in the TSD.

During FY12, INL generated 78,965 $\mathrm{MT}$ of $\mathrm{CO}_{2}$ equivalents, respectively. Many factors influence INL's GHG emissions, including the large land area on which the Laboratory's facilities are located. The area requires long commutes and an extensive fleet to provide transportation for desert Site workers, and contains antiquated facilities that were built before the current appreciation for energy efficiency and high-performance design. These factors tie directly to the following conclusions from INL's FY12 GHG inventory:

- Electricity (including the associated transmission and distribution losses) is the largest contributor to INL's GHG inventory, with over $50 \%$ of the $\mathrm{CO}_{2} \mathrm{e}$ emissions 
- Other sources with high emissions were employee commuting, mobile combustion (fleet fuels), stationary combustion (facility fuels), business air travel, and waste disposal (including fugitive emissions from the onsite landfill and contracted disposal)

- Sources with low emissions were wastewater treatment (onsite and contracted), business ground travel (in personal and rental vehicles), and fugitive emissions from refrigerants.

INL's GHG inventory for FY12 was performed according the guidelines contained in the TSD. INL recognizes its role as a DOE-sponsored research laboratory to "lead by example" in measuring, reporting, and reducing GHG emissions. To that end, the Laboratory has already moved to promote reductions in GHGs. Now that 5 years of data have been gathered, the next step is to continue to implement GHG reduction strategy activities into everyday operations that will contribute to the EO goals and continue to reduce GHG emissions. 


\section{REFERENCES}

74 FR 56260, "Final Rule: EPA Mandatory Reporting of Greenhouse Gases,” 40 CFR 98, http://www.epa.gov/ghgreporting/documents/pdf/2009/GHG-MRR-FinalRule.pdf, Web page accessed January 2013.

ABC News/Technology, "Poll: Traffic in the United States, A Look under the Hood of a Nation on Wheels," February 13, 2005, http://abcnews.go.com/Technology/Traffic/story?id=485098\&page=1, Web page accessed August 2010.

EPA, Appendix B, "Standard Volume-to-Weight Conversion Factors," Environmental Protection Agency, www.epa.gov/epawaste/conserve/tools/recmeas/docs/guide_b.pdf, Web page accessed January 2013.

EPA Climate Leaders, Commuting, Business Travel \& Mobile Transport, EPA 430-R-08-006, May 2008.

EPA Climate Leaders, Mobile Sources Guidance, www.epa.gov/stateply/documents/resources/mobilesource guidance.pdf, Web page accessed August 2010.

EPA, eGRID2012 Version 1.0, Summary Tables, p. 3, 2012, http://www.epa.gov/cleanenergy/documents/egridzips/eGRID2012V1_0_year09_SummaryTables.pdf , Web page accessed January 2013.

Executive Order (EO) 13514, "Federal Leadership in Environmental, Energy, and Economic Performance," October 5, 2009.

Federal Greenhouse Gas Accounting and Reporting Guidance, Revision 1: June 4, 2012

Federal Greenhouse Gas Accounting and Reporting Guidance: Technical Support Document, October 6, 2010.

Western Renewable Energy Generation Information System (WREGIS), "Certificates in Subaccount," November 5, 2012. See Appendix F.

White House, "President Obama Sets Greenhouse Gas Emissions Reduction Target for Federal Operations,"

http://www.whitehouse.gov/the-press-office/president-obama-sets-greenhouse-gas-emissions-reductio n-target-federal-operations, January 29, 2010 (2010a).

White House, "President Obama Expands Greenhouse Gas Reduction Target for Federal Operations," http://www.whitehouse.gov/the-press-office/president-obama-expands-greenhouse-gas-reduction-targ et-federal-operations, July 20, 2010 (2010b). 


\section{Appendix A}

Global Warming Potentials 


\section{Appendix A}

\section{Global Warming Potentials}

Table A-1 below shows the GWPs for the GHGs that were considered to have been released by INL during FY12. All GWP values shown are based on those used in the EPA Mandatory Reporting Rule.

Table A-1. Global warming potentials.

\begin{tabular}{|c|c|c|c|}
\hline Name & CAS No. & Chemical Formula & $\begin{array}{c}\text { Global Warming } \\
\text { Potential } \\
\text { (100 year) }\end{array}$ \\
\hline Carbon dioxide & $124-38-9$ & $\mathrm{CO}_{2}$ & 1 \\
\hline Methane & $74-82-8$ & $\mathrm{CH}_{4}$ & 21 \\
\hline Sulfur hexafluoride & $2551-62-4$ & $\mathrm{SF}_{6}$ & 23,900 \\
\hline $\mathrm{HFC}-32$ & $75-10-5$ & $\mathrm{CH}_{2} \mathrm{~F}_{2}$ & 650 \\
\hline $\mathrm{HFC}-125$ & $354-33-6$ & $\mathrm{C}_{2} \mathrm{HF}_{5}$ & 2,800 \\
\hline HFC-134a & $811-97-2$ & $\mathrm{CH}_{2} \mathrm{FCF}_{3}$ & 1,300 \\
\hline HFC-143a & $420-46-2$ & $\mathrm{C}_{2} \mathrm{H}_{3} \mathrm{~F}_{3}$ & 3,800 \\
\hline $\mathrm{HFC}-152 \mathrm{a}$ & $75-37-6$ & $\mathrm{CH}_{3} \mathrm{CHF}_{2}$ & 140 \\
\hline HFC $-365 \mathrm{mfc}$ & $406-58-6$ & $\mathrm{CH}_{3} \mathrm{CF}_{2} \mathrm{CH}_{2} \mathrm{CF}_{3}$ & 794 \\
\hline PFC-218 & 76-19-7 & $\mathrm{C}_{3} \mathrm{~F}_{8}\left(\mathrm{CF}_{3} \mathrm{CF}_{2} \mathrm{CF}_{3}\right)$ & 7,000 \\
\hline
\end{tabular}


Appendix B

Sample Calculation 


\section{Appendix B}

\section{Sample Calculation}

This calculation for electricity is an example of the calculation steps followed for calculating the GHG emissions from each of INL's emissions categories:

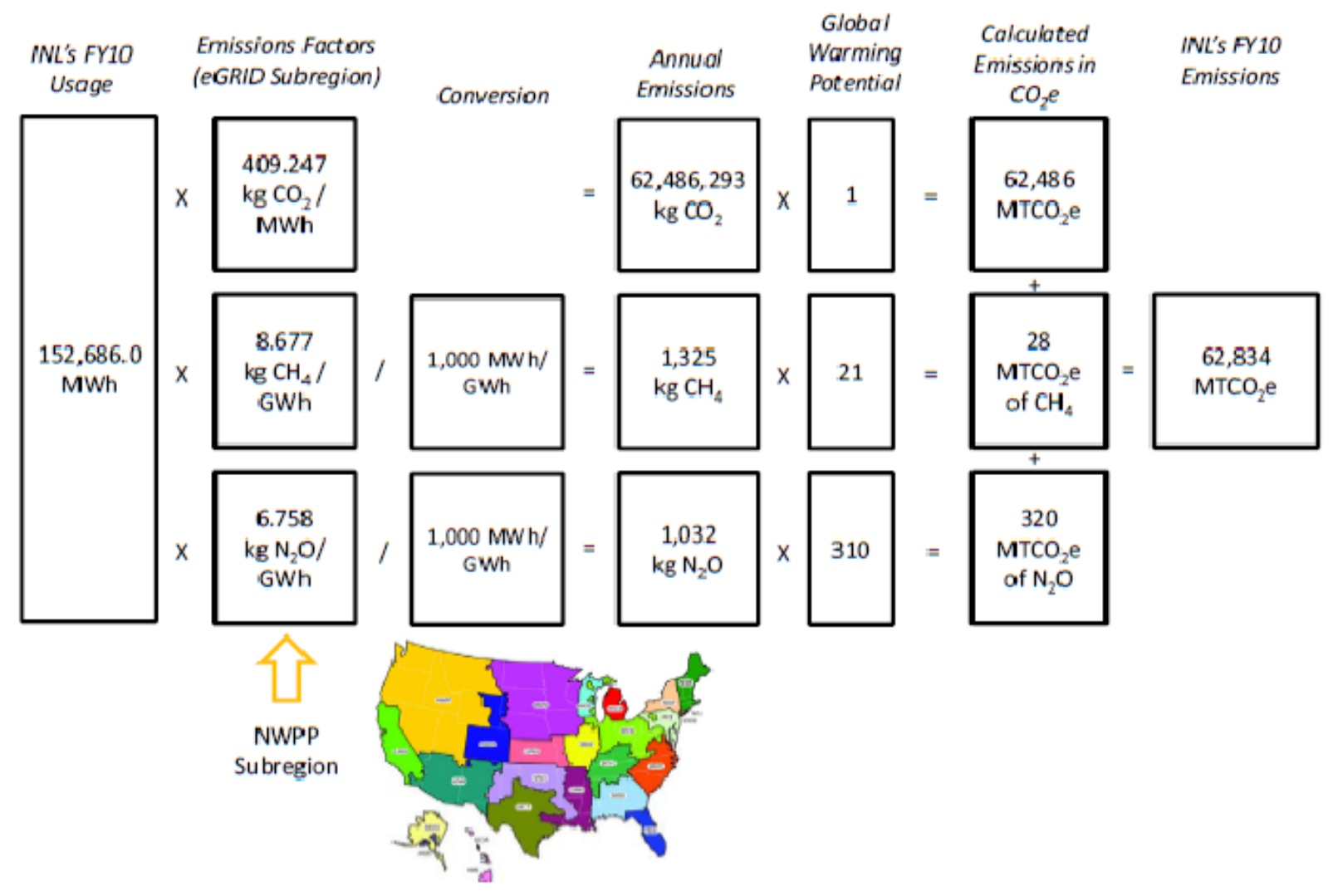


Appendix C

\section{Scope 1 Comprehensive Tables}




\section{Appendix C}

\section{Scope 1 Comprehensive Tables}

Table C-1. INL's GHG emissions from FY08 to FY12.

\begin{tabular}{|c|c|c|c|c|c|c|}
\hline Scope & Emissions Category & $\begin{array}{c}\text { FY08 } \\
\text { GHG } \\
\text { Emissions } \\
(\mathrm{MT} \\
\left.\mathrm{CO}_{2} \mathrm{e}\right)\end{array}$ & $\begin{array}{c}\text { FY09 } \\
\text { GHG } \\
\text { Emissions } \\
(\mathrm{MT} \\
\left.\mathrm{CO}_{2} \mathrm{e}\right)\end{array}$ & $\begin{array}{c}\text { FY10 } \\
\text { GHG } \\
\text { Emissions } \\
(\mathrm{MT} \\
\left.\mathrm{CO}_{2} \mathrm{e}\right)\end{array}$ & $\begin{array}{c}\text { FY11 } \\
\text { GHG } \\
\text { Emissions } \\
(\mathrm{MT} \\
\left.\mathrm{CO}_{2} \mathrm{e}\right)\end{array}$ & $\begin{array}{c}\mathrm{FY} 12 \\
\text { GHG } \\
\text { Emissions } \\
(\mathrm{MT} \\
\left.\mathrm{CO}_{2} \mathrm{e}\right)\end{array}$ \\
\hline \multirow{6}{*}{$\begin{array}{c}1 \\
(\text { Direct })\end{array}$} & Stationary Combustion & 15,213 & 13,381 & 14,288 & 9,826 & 5,682 \\
\hline & Mobile Combustion & 10,040 & 8,545 & 7,383 & 7,680 & 6,834 \\
\hline & Fugitive Emissions: Refrigerants & 245 & 200 & 385 & 640 & 481 \\
\hline & Fugitive Emissions: Onsite Landfill & 5,963 & 5,878 & 5,785 & 5,702 & 5,617 \\
\hline & $\begin{array}{l}\text { Fugitive Emissions: Onsite } \\
\text { Wastewater Treatment }\end{array}$ & 129 & 130 & 136 & 142 & 131 \\
\hline & SCOPE 1 TOTAL & 31,591 & 28,133 & 27,978 & 23,991 & 18,745 \\
\hline \multirow{4}{*}{$\begin{array}{c}2 \\
\text { (Indirect) }\end{array}$} & Purchased Electricity & 61,746 & 58,297 & 61,364 & 56,971 & 55,570 \\
\hline & $\begin{array}{l}\text { Transmission \& Distribution Losses } \\
\text { (Owned) }\end{array}$ & 1,532 & 1,450 & 1,470 & 1,109 & 975 \\
\hline & Purchased RECs & $-3,474$ & $-6,813$ & $-11,480$ & $(15,332)$ & $(14,082)$ \\
\hline & SCOPE 2 TOTAL & 59,804 & 52,934 & 51,354 & 42,748 & 42,463 \\
\hline \multirow[t]{8}{*}{$\begin{array}{c}3 \\
\text { (Indirect) }\end{array}$} & $\begin{array}{l}\text { Transmission \& Distribution Losses } \\
\text { (Shared) }\end{array}$ & 4,170 & 3,937 & 4,141 & 3,754 & 3,662 \\
\hline & Employee Commuting & 8,657 & 9,354 & 10,171 & 9,410 & 8,313 \\
\hline & Business Air Travel & 6,687 & 7,380 & 6,785 & 5,765 & 4,364 \\
\hline & $\begin{array}{l}\text { Business Ground Travel: Rental } \\
\text { Vehicle }\end{array}$ & 351 & 337 & 393 & 319 & 300 \\
\hline & $\begin{array}{l}\text { Business Ground Travel: Personal } \\
\text { Vehicle }\end{array}$ & 413 & 411 & 422 & 531 & 251 \\
\hline & Contracted MSW Disposal & 1,187 & 903 & 956 & 967 & 853 \\
\hline & Contracted Wastewater Treatment & 190 & 201 & 214 & 79 & 13 \\
\hline & SCOPE 3 TOTAL & 21,654 & 22,523 & 23,082 & 20,825 & 17,757 \\
\hline \multicolumn{2}{|c|}{ TOTAL ANTHROPOGENIC EMISSIONS ${ }^{\mathrm{a}}$} & 113,049 & 103,590 & 102,413 & 87,563 & 78,965 \\
\hline \multirow[t]{3}{*}{ Biogenic } & Mobile Combustion & 162 & 723 & 1,182 & 1,339 & 1,855 \\
\hline & Fugitive Emissions: Onsite Landfill & 866 & 853 & 840 & 828 & 816 \\
\hline & Contracted MSW Disposal & 155 & 118 & 125 & 127 & 112 \\
\hline \multicolumn{2}{|c|}{ TOTAL BIOGENIC EMISSIONS } & 1,184 & 1,695 & 2,148 & 2,294 & 2,782 \\
\hline \multicolumn{2}{|c|}{$\begin{array}{l}\text { TOTAL EMISSIONS (ANTHROPOGENIC + } \\
\text { BIOGENIC) }\end{array}$} & 114,233 & 105,285 & 104,561 & 89,857 & 81,747 \\
\hline
\end{tabular}


Table C-2. Amounts of fuel used for stationary combustion at INL during FY08.

\begin{tabular}{|l|c|c|c|}
\hline \multirow{2}{*}{\multicolumn{1}{|c|}{ Energy Type }} & \multicolumn{2}{c|}{ Fuel Used } & \multirow{2}{*}{$\begin{array}{c}\text { GHG Emissions } \\
\left(\mathrm{MT} \mathrm{CO}_{2} \mathrm{e}\right)\end{array}$} \\
\cline { 2 - 3 } & Amount & Units & 12,771 \\
\hline Fuel Oil No. 2 & $1,247,088$ & Gallons & 321 \\
\hline Liquefied Natural Gas (LNG) & 43,590 & Gallons & 870 \\
\hline Liquefied Propane Gas (LPG) & 149,475 & Gallons & 1,252 \\
\hline Natural Gas (Pipeline) & 236,600 & Therms & 15,213 \\
\hline \multicolumn{3}{|r}{} \\
\hline
\end{tabular}

Table C-3. Amounts of fuel used for stationary combustion at INL during FY09.

\begin{tabular}{|l|c|l|c|}
\hline \multirow{2}{*}{\multicolumn{1}{|c|}{ Energy Type }} & \multicolumn{2}{c|}{ Fuel Used } & \multirow{2}{*}{$\begin{array}{c}\text { GHG Emissions } \\
\left(\mathrm{MT} \mathrm{CO}_{2} \mathrm{e}\right)\end{array}$} \\
\cline { 2 - 3 } & Amount & \multicolumn{1}{c|}{ Units } & 11,250 \\
\hline Fuel Oil No. 2 & $1,098,582$ & Gallons & 304 \\
\hline Liquefied Natural Gas (LNG) & 41,259 & Gallons & 434 \\
\hline Liquefied Propane Gas (LPG) & 74,660 & Gallons & 1,392 \\
\hline Natural Gas (Pipeline) & 263,099 & Therms & 13,381 \\
\hline \multicolumn{3}{|c|}{ TOTAL } \\
\hline
\end{tabular}

Table C-4. Amounts of fuel used for stationary combustion at INL during FY10.

\begin{tabular}{|l|c|l|c|}
\hline \multirow{2}{*}{\multicolumn{1}{|c|}{ Energy Type }} & \multicolumn{2}{c|}{ Fuel Used } & \multirow{2}{*}{$\begin{array}{c}\text { GHG Emissions } \\
\left(\mathrm{MT} \mathrm{CO}_{2} \mathrm{e}\right)\end{array}$} \\
\cline { 2 - 3 } & Amount & \multicolumn{1}{c|}{ Units } & 12,020 \\
\hline Fuel Oil No. 2 & $1,173,716$ & Gallons & 318 \\
\hline Liquefied Natural Gas (LNG) & 43,284 & Gallons & 556 \\
\hline Liquefied Propane Gas (LPG) & 95,586 & Gallons & 1,394 \\
\hline Natural Gas (Pipeline) & 263,433 & Therms & 14,288 \\
\hline \multicolumn{3}{|c|}{ TOTAL } \\
\hline
\end{tabular}

Table C-5. Amounts of fuel used for stationary combustion at INL during FY11.

\begin{tabular}{|l|c|l|c|}
\hline \multirow{2}{*}{\multicolumn{1}{|c|}{ Energy Type }} & \multicolumn{2}{c|}{ Fuel Used } & \multirow{2}{*}{$\begin{array}{c}\text { GHG Emissions } \\
\left(\mathrm{MT} \mathrm{CO}_{2} \mathrm{e}\right)\end{array}$} \\
\cline { 2 - 3 } & Amount & \multicolumn{1}{c|}{ Units } & 7,691 \\
\hline Fuel Oil No. 2 & 751,045 & Gallons & 260 \\
\hline Liquefied Natural Gas (LNG) & 35,392 & Gallons & 341 \\
\hline Liquefied Propane Gas (LPG) & 58,659 & Gallons & 1,533 \\
\hline Natural Gas (Pipeline) & 289,757 & Therms & 9,826 \\
\hline \multicolumn{3}{|c|}{ TOTAL } \\
\hline
\end{tabular}


Table C-6. Amounts of fuel used for stationary combustion at INL during FY12.

\begin{tabular}{|l|c|l|c|}
\hline \multirow{2}{*}{\multicolumn{1}{c|}{ Energy Type }} & \multicolumn{2}{c|}{ Fuel Used } & \multirow{2}{*}{$\begin{array}{c}\text { GHG Emissions } \\
\left(\mathrm{MT} \mathrm{CO}_{2} \mathrm{e}\right)\end{array}$} \\
\cline { 2 - 3 } & Amount & \multicolumn{1}{c|}{ Units } & 3,805 \\
\hline Fuel Oil No. 2 & 371,587 & Gallons & 267 \\
\hline Liquefied Natural Gas (LNG) & 36,263 & Gallons & 310 \\
\hline Liquefied Propane Gas (LPG) & 53,366 & Gallons & 1,299 \\
\hline Natural Gas (Pipeline) & 245,554 & Therms & 5,682 \\
\hline \multicolumn{2}{|c|}{ TOTAL } \\
\hline
\end{tabular}


Table C-7. Fuel amounts and corresponding GHG emissions for INL's FY08 fleet.

\begin{tabular}{|c|c|c|c|c|}
\hline Fuel Type & Vehicle Type & $\begin{array}{l}\text { Fuel Used } \\
\text { (gal) }\end{array}$ & $\begin{array}{c}\mathrm{GHG} \\
\text { Emissions } \\
\left(\mathrm{MT} \mathrm{CO}_{2} \mathrm{e}\right)\end{array}$ & $\begin{array}{c}\text { Biogenic } \\
\text { Emissions } \\
\left(\mathrm{MT} \mathrm{CO}_{2} \mathrm{e}\right)\end{array}$ \\
\hline \multirow[t]{4}{*}{ B15 Biodiesel Blend $^{\mathrm{a}}$} & Bus & $50,677.20$ & 440 & 72 \\
\hline & Equipment & 77.10 & 1 & $<1$ \\
\hline & Heavy Duty & 836.50 & 7 & 1.19 \\
\hline & Light-Duty Truck & 19.60 & $<1$ & $<1$ \\
\hline \multirow[t]{3}{*}{ Compressed Natural Gas (CNG) } & Bus & 90.00 & 1 & - \\
\hline & Light-Duty Car & 54.30 & $<1$ & - \\
\hline & Light-Duty Truck & 437.40 & 3 & - \\
\hline \multirow[t]{4}{*}{ Diesel } & Bus & $544,548.50$ & 5,563 & - \\
\hline & Equipment & $50,229.00$ & 517 & - \\
\hline & Heavy Duty & $50,066.80$ & 512 & - \\
\hline & Light-Duty Truck & $10,326.70$ & 105 & - \\
\hline \multirow[t]{2}{*}{ E85 Ethanol Fuel Blend } & Light-Duty Car & $2,063.20$ & 4 & 10.08 \\
\hline & Light-Duty Truck & $16,195.00$ & 27 & 79.14 \\
\hline \multirow[t]{5}{*}{ Gasoline } & Bus & $2,391.50$ & 21 & - \\
\hline & Equipment & $5,803.10$ & 51 & - \\
\hline & Heavy Duty & $6,852.90$ & 64 & - \\
\hline & Light-Duty Car & $15,529.40$ & 141 & - \\
\hline & Light-Duty Truck & $241,383.42$ & 2,228 & - \\
\hline \multirow[t]{2}{*}{ LNG } & Bus & $45,964.30$ & 348 & - \\
\hline & Light-Duty Truck & 30.00 & $<1$ & - \\
\hline Propane & Equipment & 851.90 & 5 & - \\
\hline \multicolumn{2}{|c|}{ TOTAL } & $1,044,427.83$ & 10,040 & 162 \\
\hline
\end{tabular}

Since the vehicle type category was reported a bit differently than the subsequent years, only FY09FY12 is combined in the comprehensive table on the following page. 
Table C-8. Fuel amounts and corresponding GHG emissions for INL's fleet-FY09 to FY11.

\begin{tabular}{|c|c|c|c|c|c|c|c|c|c|c|}
\hline \multirow[b]{2}{*}{ Fuel Type } & \multirow[b]{2}{*}{ Vehicle Type } & \multicolumn{3}{|c|}{ FY09 } & \multicolumn{3}{|c|}{ FY10 } & \multicolumn{3}{|c|}{ FY11 } \\
\hline & & $\begin{array}{c}\text { Fuel Used } \\
\text { (gal) }\end{array}$ & $\begin{array}{c}\text { GHG } \\
\text { Emissions } \\
\left(\mathrm{MT} \mathrm{CO}_{2} \mathrm{e}\right)\end{array}$ & $\begin{array}{c}\text { Biogenic } \\
\text { Emissions } \\
\left(\mathrm{MT} \mathrm{CO}_{2} \mathrm{e}\right)\end{array}$ & $\begin{array}{l}\text { Fuel Used } \\
\text { (gal) }\end{array}$ & $\begin{array}{c}\mathrm{GHG} \\
\text { Emissions } \\
\left(\mathrm{MT} \mathrm{CO}_{2} \mathrm{e}\right) \\
\end{array}$ & $\begin{array}{c}\text { Biogenic } \\
\text { Emissions } \\
\left(\mathrm{MT} \mathrm{CO}_{2} \mathrm{e}\right) \\
\end{array}$ & $\begin{array}{c}\text { Fuel Used } \\
(\mathrm{gal})\end{array}$ & $\begin{array}{c}\text { GHG } \\
\text { Emissions } \\
\left(\mathrm{MT} \mathrm{CO}_{2} \mathrm{e}\right) \\
\end{array}$ & $\begin{array}{c}\text { Biogenic } \\
\text { Emissions } \\
\left(\mathrm{MT} \mathrm{CO}_{2} \mathrm{e}\right)\end{array}$ \\
\hline \multirow[t]{4}{*}{ B15 Biodiesel Blend ${ }^{\mathrm{a}}$} & Bus & $219,814.50$ & 1,909 & 312 & $331,916.34$ & 2,883 & 471 & $363,731.46$ & 3,159 & 516 \\
\hline & Equipment & $9,462.90$ & 83 & 13 & $14,256.11$ & 125 & 20 & $5,454.84$ & 48 & 8 \\
\hline & Light-Duty Truck & $6,551.70$ & 57 & 9 & $8,797.74$ & 76 & 12 & $2,118.54$ & 18 & 3 \\
\hline & Truck & $2,351.00$ & 20 & 3 & $3,061.95$ & 27 & 4 & 546.93 & 5 & 1 \\
\hline \multirow[t]{4}{*}{ Diesel } & Bus & $302,302.50$ & 3,088 & - & $186,610.28$ & 1,906 & - & $164,017.55$ & 1,676 & - \\
\hline & Equipment & $96,249.70$ & 991 & - & $54,192.00$ & 558 & - & $78,481.02$ & 808 & - \\
\hline & Heavy Duty & $21,369.20$ & 218 & - & $20,127.87$ & 206 & - & $32,963.00$ & 337 & - \\
\hline & Light-Duty Truck & $6,071.00$ & 62 & - & $5,553.66$ & 57 & - & $7,540.25$ & 77 & - \\
\hline \multirow[t]{4}{*}{ E10 Ethanol Fuel Blend } & Bus & $1,138.60$ & 9 & $<1$ & 76.20 & $<1$ & $<1$ & --- & --- & --- \\
\hline & Equipment & $76,793.90$ & 615 & 44 & $19,590.83$ & 157 & 11 & $22,401.88$ & 179 & 13 \\
\hline & Light-Duty Car & $14,218.80$ & 117 & 8 & $6,646.48$ & 56 & 4 & $6,242.52$ & 52 & 4 \\
\hline & Light-Duty Truck & $122,823.80$ & 1,025 & 71 & $4,134.43$ & 34 & 2 & $1,907.45$ & 16 & 1 \\
\hline \multirow[t]{4}{*}{ E85 Ethanol Fuel Blend } & Bus & 66.80 & $<1$ & $<1$ & $130,063.10$ & 1,085 & 75 & $125,990.31$ & 1,051 & 72 \\
\hline & Equipment & $3,223.90$ & 5 & 16 & $1,946.67$ & 3 & 10 & 647.81 & 1 & 3 \\
\hline & Light-Duty Car & $3,398.35$ & 6 & 17 & $8,457.22$ & 15 & 41 & $8,583.05$ & 15 & 42 \\
\hline & Light-Duty Truck & $46,965.15$ & 80 & 230 & $108,806.18$ & 186 & 532 & $138,476.16$ & 236 & 677 \\
\hline Gasoline & Equipment & $1,717.30$ & 15 & - & 845.60 & 7 & - & --- & --- & --- \\
\hline \multirow[t]{2}{*}{ LNG } & Bus & $31,771.00$ & 241 & - & 38.00 & $<1$ & - & --- & --- & --- \\
\hline & Equipment & 231.00 & 2 & - & 76.00 & $<1$ & - & --- & --- & --- \\
\hline \multicolumn{2}{|r|}{ TOTAL } & $966,521.10$ & 8,545 & 723 & $905,196.64$ & 7,383 & 1,182 & $959,102.76$ & 7,680 & 1,339 \\
\hline
\end{tabular}

that can be easily reported). Assume a 50/50 split of B10 and B20, and refer to the biodiesel blend as B15. Tad Pearson confirmed in a December 22, 2010 phone call that this assumption was valid for FY09 and FY10. 
Table C-9. Fuel amounts and corresponding GHG emissions for INL's FY12 fleet.

\begin{tabular}{|c|c|c|c|c|}
\hline Fuel Type & Vehicle Type & $\begin{array}{l}\text { Fuel Used } \\
\text { (gal) }\end{array}$ & $\begin{array}{c}\text { GHG } \\
\text { Emissions } \\
\left(\mathrm{MT} \mathrm{CO}_{2} \mathrm{e}\right)\end{array}$ & $\begin{array}{c}\text { Biogenic } \\
\text { Emissions } \\
\left(\mathrm{MT} \mathrm{CO}_{2} \mathrm{e}\right)\end{array}$ \\
\hline \multirow[t]{4}{*}{ B20 Biodiesel Blend $^{\mathrm{a}}$} & Bus & $389,607.82$ & $3,184.95$ & 736.48 \\
\hline & Equipment & $4,026.97$ & 33.24 & 5.71 \\
\hline & Heavy Duty & 765.48 & 6.26 & 1.45 \\
\hline & Light-Duty Truck & - & - & - \\
\hline \multirow[t]{3}{*}{ Compressed Natural Gas (CNG) } & Bus & - & - & - \\
\hline & Light-Duty Car & - & - & - \\
\hline & Light-Duty Truck & - & - & - \\
\hline \multirow[t]{4}{*}{ Diesel } & Bus & $106,683.01$ & $1,089.88$ & - \\
\hline & Equipment & $46,311.52$ & 476.97 & - \\
\hline & Heavy Duty & $26,717.37$ & 273.07 & - \\
\hline & Light-Duty Truck & $6,966.56$ & 71.16 & - \\
\hline \multirow[t]{2}{*}{ E85 Ethanol Fuel Blend } & Light-Duty Car & - & - & - \\
\hline & Light-Duty Truck & $23,021.54$ & 184.29 & 13.23 \\
\hline \multirow[t]{5}{*}{ Gasoline } & Bus & $3,464.86$ & 29.08 & 1.99 \\
\hline & Equipment & $1,625.20$ & 13.38 & 0.93 \\
\hline & Heavy Duty & $133,636.56$ & $1,114.90$ & 76.83 \\
\hline & Light-Duty Car & - & - & - \\
\hline & Light-Duty Truck & $1,367.85$ & 2.29 & 6.68 \\
\hline \multicolumn{2}{|r|}{ TOTAL } & $951,170.45$ & $6,833.91$ & $1,854.72$ \\
\hline
\end{tabular}


Table C-10. Fugitive refrigerants evaluated for GHG emissions from FY08 to FY12 at INL.

\begin{tabular}{|c|c|c|c|c|c|c|c|c|c|c|c|}
\hline \multirow[b]{2}{*}{ Common Name } & \multirow[b]{2}{*}{ GWP } & \multicolumn{2}{|c|}{ FY08 } & \multicolumn{2}{|c|}{ FY09 } & \multicolumn{2}{|c|}{ FY10 } & \multicolumn{2}{|c|}{ FY11 } & \multicolumn{2}{|c|}{ FY12 } \\
\hline & & $\begin{array}{c}\text { Mass } \\
\text { Emitted } \\
\text { (lbs.) }\end{array}$ & $\begin{array}{c}\mathrm{GHG} \\
\text { Emissions } \\
(\mathrm{MT} \\
\left.\mathrm{CO}_{2} \mathrm{e}\right) \\
\end{array}$ & $\begin{array}{c}\text { Mass } \\
\text { Emitted } \\
(\mathrm{lbs}) \\
\end{array}$ & $\begin{array}{c}\mathrm{GHG} \\
\text { Emissions } \\
(\mathrm{MT} \\
\left.\mathrm{CO}_{2} \mathrm{e}\right) \\
\end{array}$ & $\begin{array}{c}\text { Mass } \\
\text { Emitted } \\
(\mathrm{lbs})\end{array}$ & $\begin{array}{c}\mathrm{GHG} \\
\text { Emissions } \\
(\mathrm{MT} \\
\left.\mathrm{CO}_{2} \mathrm{e}\right) \\
\end{array}$ & $\begin{array}{c}\text { Mass } \\
\text { Emitted } \\
(\mathrm{lbs})\end{array}$ & $\begin{array}{c}\mathrm{GHG} \\
\text { Emissions } \\
(\mathrm{MT} \\
\left.\mathrm{CO}_{2} \mathrm{e}\right) \\
\end{array}$ & $\begin{array}{c}\text { Mass } \\
\text { Emitted } \\
(\mathrm{lbs})\end{array}$ & $\begin{array}{c}\mathrm{GHG} \\
\text { Emissions } \\
\left(\mathrm{MT} \mathrm{CO}_{2} \mathrm{e}\right)\end{array}$ \\
\hline $\mathrm{CO}_{2}$ & 1 & NE & NE & $20,072.60$ & 9 & $1,849.18$ & 1 & $1,849.18$ & 1 & 3.22 & 0.0 \\
\hline $\mathrm{CH}_{4}$ & 21 & $\mathrm{NE}$ & $\mathrm{NE}$ & $2,842.50$ & 27 & $32,961.47$ & 314 & $32,961.47$ & 314 & -588.29 & -5.6 .0 \\
\hline $\mathrm{N}_{2} \mathrm{O}$ & 310 & $\mathrm{NE}$ & $\mathrm{NE}$ & 0.00 & 0 & 20.18 & 3 & 20.18 & 3 & 0.0 & 0.0 \\
\hline HFC-23 & 11,700 & 0.43 & 2 & 1.50 & 8 & 0.0 & 0 & 0.0 & 0 & 0.0 & 0.0 \\
\hline HFC-32 & 650 & 71.99 & 21 & 0.00 & 0 & 92.13 & 27 & 92.13 & 27 & 180.5 & 53.22 \\
\hline HFC-41 & 150 & 0.00 & 0 & 0.00 & 0 & 0.0 & 0 & 0.0 & 0 & 0.0 & 0.0 \\
\hline HFC-125 & 2,800 & 88.98 & 113 & 0.00 & 0 & 100.15 & 127 & 100.15 & 127 & 60.12 & 76.35 \\
\hline HFC-134 & 1,000 & 0.00 & 0 & 0.00 & 0 & 0.0 & 0 & 0.0 & 0 & 0.0 & 0.0 \\
\hline HFC-134a & 1,300 & 173.15 & 102 & 238.20 & 140 & 316.35 & 187 & 316.35 & 187 & 419.61 & 247.44 \\
\hline HFC-143 & 300 & 0.00 & 0 & 0.00 & 0 & 0.0 & 0 & 0.0 & 0 & 0.0 & 0.0 \\
\hline HFC-143a & 3,800 & 0.20 & $<1$ & 0.00 & 0 & -18.72 & -32 & -18.72 & -32 & 20.76 & 35.78 \\
\hline HFC-152 & 53 & 0.00 & 0 & 0.00 & 0 & 0.0 & 0 & 0.0 & 0 & 0.0 & 0.0 \\
\hline HFC-152a & 140 & 23.88 & 2 & 23.50 & 1 & 3.28 & 0 & 3.28 & 0 & 77.22 & 4.90 \\
\hline HFC-161 & 12 & 0.00 & 0 & 0.00 & 0 & 0.0 & 0 & 0.0 & 0 & 0.0 & 0.0 \\
\hline $\mathrm{HFC}-227 \mathrm{ca}$ & 2,900 & 0.00 & 0 & 0.00 & 0 & 0.0 & 0 & 0.0 & 0 & 0.0 & 0.0 \\
\hline HFC-227ea & 2,900 & 0.00 & 0 & 0.00 & 0 & 46.0 & 61 & 46.0 & 61 & 0.0 & 0.0 \\
\hline HFC-236ca & 120 & 0.00 & 0 & 0.00 & 0 & 0.0 & 0 & 0.0 & 0 & 0.0 & 0.0 \\
\hline HFC-236cb & 1,340 & 0.00 & 0 & 0.00 & 0 & 0.0 & 0 & 0.0 & 0 & 0.0 & 0.0 \\
\hline HFC-236ea & 1,370 & 0.00 & 0 & 0.00 & 0 & 0.0 & 0 & 0.0 & 0 & 0.0 & 0.0 \\
\hline HFC-236fa & 6,300 & 0.00 & 0 & 0.00 & 0 & 0.0 & 0 & 0.0 & 0 & 0.0 & 0.0 \\
\hline HFC-245ca & 560 & 0.00 & 0 & 0.00 & 0 & 0.0 & 0 & 0.0 & 0 & 0.0 & 0.0 \\
\hline HFC-245fa & 1,030 & 0.00 & 0 & 0.00 & 0 & 0.0 & 0 & 0.0 & 0 & 0.0 & 0.0 \\
\hline HFC-365mfc & 794 & 3.86 & 1 & 38.00 & 14 & -0.4 & 0 & -0.4 & 0 & 0.9 & 0.32 \\
\hline HFC-c-447-ef & 250 & 0.00 & 0 & 0.00 & 0 & $\mathrm{NE}$ & $\mathrm{NE}$ & $\mathrm{NE}$ & $\mathrm{NE}$ & NE & $\mathrm{NE}$ \\
\hline HFC-43-10mee & 1,300 & 1.69 & 1 & 0.00 & 0 & 0.0 & 0 & 0.0 & 0 & 0.0 & 0.0 \\
\hline PFC-14 & 6,500 & 0.00 & 0 & 0.00 & 0 & 0.0 & 0 & 0.0 & 0 & 0.0 & 0.0 \\
\hline
\end{tabular}


Table C-10. (continued).

\begin{tabular}{|c|c|c|c|c|c|c|c|c|c|c|c|}
\hline \multirow[b]{2}{*}{ Common Name } & \multirow[b]{2}{*}{ GWP } & \multicolumn{2}{|c|}{ FY08 } & \multicolumn{2}{|c|}{ FY09 } & \multicolumn{2}{|c|}{ FY10 } & \multicolumn{2}{|c|}{ FY11 } & \multicolumn{2}{|c|}{ FY12 } \\
\hline & & $\begin{array}{l}\text { Mass } \\
\text { Emitted } \\
\text { (lbs.) }\end{array}$ & $\begin{array}{c}\mathrm{GHG} \\
\text { Emissions } \\
(\mathrm{MT} \\
\left.\mathrm{CO}_{2} \mathrm{e}\right) \\
\end{array}$ & $\begin{array}{c}\text { Mass } \\
\text { Emitted } \\
(\mathrm{lbs}) \\
\end{array}$ & $\begin{array}{c}\mathrm{GHG} \\
\text { Emissions } \\
(\mathrm{MT} \\
\left.\mathrm{CO}_{2} \mathrm{e}\right) \\
\end{array}$ & $\begin{array}{c}\text { Mass } \\
\text { Emitted } \\
(\mathrm{lbs})\end{array}$ & $\begin{array}{c}\text { GHG } \\
\text { Emissions } \\
(\mathrm{MT} \\
\left.\mathrm{CO}_{2} \mathrm{e}\right) \\
\end{array}$ & $\begin{array}{c}\text { Mass } \\
\text { Emitted } \\
(\mathrm{lbs}) \\
\end{array}$ & $\begin{array}{c}\text { GHG } \\
\text { Emissions } \\
(\mathrm{MT} \\
\left.\mathrm{CO}_{2} \mathrm{e}\right) \\
\end{array}$ & $\begin{array}{c}\text { Mass } \\
\text { Emitted } \\
(\mathrm{lbs}) \\
\end{array}$ & $\begin{array}{c}\mathrm{GHG} \\
\text { Emissions } \\
\left(\mathrm{MT} \mathrm{CO}_{2} \mathrm{e}\right)\end{array}$ \\
\hline PFC-116 & 9,200 & 0.51 & 2 & 0.00 & 0 & 0.0 & 0 & 0.0 & 0 & 0.0 & 0.0 \\
\hline PFC-218 & 7,000 & 0.00 & 0 & 0.00 & 0 & 0.0 & 0 & 0.0 & 0 & 1.1 & 3.5 \\
\hline $\begin{array}{l}\text { PFC-318 or } \\
\text { PFCc } 318\end{array}$ & 8,700 & 0.00 & 0 & 0.00 & 0 & 0.0 & 0 & 0.0 & 0 & 0.0 & 0.0 \\
\hline PFC-3-1-10 & 7,000 & 0.00 & 0 & 0.00 & 0 & 0.0 & 0 & 0.0 & 0 & 0.0 & 0.0 \\
\hline PFC-4-1-12 & 7,500 & 0.00 & 0 & 0.00 & 0 & 0.0 & 0 & 0.0 & 0 & 0.0 & 0.0 \\
\hline PFC-5-1-14 & 7,400 & 0.00 & 0 & 0.00 & 0 & 0.0 & 0 & 0.0 & 0 & 0.0 & 0.0 \\
\hline PFC-9-1-18 & 7,500 & 0.00 & 0 & 0.00 & 0 & 0.0 & 0 & 0.0 & 0 & 0.0 & 0.0 \\
\hline $\mathrm{c}-\mathrm{C}_{3} \mathrm{~F}_{6}$ & 17,340 & 0.00 & 0 & 0.00 & 0 & 0.0 & 0 & 0.0 & 0 & 0.0 & 0.0 \\
\hline $\begin{array}{l}\mathrm{SF}_{6}-\text { Sulfur } \\
\text { Hexafluoride }\end{array}$ & 23,900 & 0.00 & 0 & 0.00 & 0 & -4.28 & -46 & -4.28 & -46 & 6.0 & 65.05 \\
\hline $\mathrm{NF}_{3}$ & 17,200 & 0.00 & 0 & 0.00 & 0 & 0.0 & 0 & 0.0 & 0 & 0.0 & 0.0 \\
\hline & TOTAL & 364.69 & 245 & $23,216.30$ & 200 & $29,242.00$ & 385 & $35,365.34$ & 640 & 181.15 & 480.96 \\
\hline
\end{tabular}


Appendix D

\section{Emissions Factors Used}




\section{Appendix D}

\section{Emissions Factors Used \\ D-1. SCOPE ONE - DIRECT EMISSIONS}

Table D-1. Stationary combustion conversion and emissions factors used.

\begin{tabular}{|c|c|c|c|c|}
\hline $\begin{array}{l}\text { Emissions } \\
\text { Source }\end{array}$ & Factor Type & Amount & Units & Reference \\
\hline \multirow[t]{4}{*}{ Fuel Oil No. 2} & $\begin{array}{l}\text { Higher Heating } \\
\text { Value (HHV) } \\
\text { Conversion } \\
\text { Factor }\end{array}$ & 0.138 & MMBtu/gal & $\begin{array}{l}\text { EPA Mandatory Reporting Rule, } \\
40 \text { CFR 98, Table C-1 to Subpart C of } \\
\text { Part } 98 .\end{array}$ \\
\hline & $\begin{array}{l}\mathrm{CO}_{2} \text { Emission } \\
\text { Factor }\end{array}$ & 73.96 & $\begin{array}{l}\mathrm{kg} \mathrm{CO}_{2} / \\
\mathrm{MMBtu}\end{array}$ & $\begin{array}{l}\text { EPA Mandatory Reporting Rule, } \\
40 \text { CFR 98, Table C-1 to Subpart C of } \\
\text { Part } 98 .\end{array}$ \\
\hline & $\begin{array}{l}\mathrm{CH}_{4} \text { Emission } \\
\text { Factor }\end{array}$ & 0.003 & $\begin{array}{l}\mathrm{kg} \mathrm{CH}_{4} / \\
\mathrm{MMBtu}\end{array}$ & $\begin{array}{l}\text { EPA Mandatory Reporting Rule, } \\
40 \text { CFR 98, Table C-2 to Subpart C of } \\
\text { Part } 98 .\end{array}$ \\
\hline & $\begin{array}{l}\mathrm{N}_{2} \mathrm{O} \text { Emission } \\
\text { Factor }\end{array}$ & 0.0006 & $\begin{array}{l}\mathrm{kg} \mathrm{N}_{2} \mathrm{O} / \\
\mathrm{MMBtu}\end{array}$ & $\begin{array}{l}\text { EPA Mandatory Reporting Rule, } \\
40 \text { CFR 98, Table C-2 to Subpart C of } \\
\text { Part } 98 .\end{array}$ \\
\hline \multirow[t]{4}{*}{$\begin{array}{l}\text { Liquefied } \\
\text { Natural Gas } \\
\text { (LNG) }\end{array}$} & $\begin{array}{l}\text { HHV } \\
\text { Conversion } \\
\text { Factor } \\
\end{array}$ & 0.110 & MMBtu/gal & $\begin{array}{l}\text { EPA Mandatory Reporting Rule, } \\
40 \text { CFR 98, Table C-1 to Subpart C of } \\
\text { Part } 98 .\end{array}$ \\
\hline & $\begin{array}{l}\mathrm{CO}_{2} \text { Emission } \\
\text { Factor }\end{array}$ & 66.83 & $\begin{array}{l}\mathrm{kg} \mathrm{CO}_{2} / \\
\mathrm{MMBtu}\end{array}$ & $\begin{array}{l}\text { EPA Mandatory Reporting Rule, } \\
40 \text { CFR 98, Table C-1 to Subpart C of } \\
\text { Part } 98 .\end{array}$ \\
\hline & $\begin{array}{l}\mathrm{CH}_{4} \text { Emission } \\
\text { Factor }\end{array}$ & 0.001 & $\begin{array}{l}\mathrm{kg} \mathrm{CH}_{4} / \\
\mathrm{MMBtu}\end{array}$ & $\begin{array}{l}\text { EPA Mandatory Reporting Rule, } \\
40 \text { CFR 98, Table C-2 to Subpart C of } \\
\text { Part } 98 .\end{array}$ \\
\hline & $\begin{array}{l}\mathrm{N}_{2} \mathrm{O} \text { Emission } \\
\text { Factor }\end{array}$ & 0.0001 & $\begin{array}{l}\mathrm{kg} \mathrm{N}_{2} \mathrm{O} / \\
\mathrm{MMBtu}\end{array}$ & $\begin{array}{l}\text { EPA Mandatory Reporting Rule, } \\
40 \text { CFR } 98 \text {, Table C-2 to Subpart C of } \\
\text { Part } 98 .\end{array}$ \\
\hline \multirow[t]{4}{*}{$\begin{array}{l}\text { Natural Gas } \\
\text { (Pipeline) }\end{array}$} & $\begin{array}{l}\text { Conversion } \\
\text { Factor }\end{array}$ & 0.001028 & MMBtu/scf & $\begin{array}{l}\text { EPA Mandatory Reporting Rule, } \\
40 \text { CFR 98, Table C-1 to Subpart C of } \\
\text { Part } 98 .\end{array}$ \\
\hline & $\begin{array}{l}\text { Conversion } \\
\text { Factor }\end{array}$ & 96.99 & scf/therm & $\begin{array}{l}\text { Published conversion in common } \\
\text { literature. }\end{array}$ \\
\hline & $\begin{array}{l}\mathrm{CO}_{2} \text { Emission } \\
\text { Factor }\end{array}$ & 53.02 & $\begin{array}{l}\mathrm{kg} \mathrm{CO}_{2} / \\
\text { MMBtu }\end{array}$ & $\begin{array}{l}\text { EPA Mandatory Reporting Rule, } \\
40 \text { CFR } 98 \text {, Table C-1 to Subpart C of } \\
\text { Part } 98 .\end{array}$ \\
\hline & $\begin{array}{l}\mathrm{CH}_{4} \text { Emission } \\
\text { Factor }\end{array}$ & 0.001 & $\begin{array}{l}\mathrm{kg} \mathrm{CH}_{4} / \\
\mathrm{MMBtu}\end{array}$ & $\begin{array}{l}\text { EPA Mandatory Reporting Rule, } \\
40 \text { CFR 98, Table C-2 to Subpart C of } \\
\text { Part } 98 .\end{array}$ \\
\hline
\end{tabular}


Table D-1. (continued).

\begin{tabular}{|c|c|c|c|c|}
\hline $\begin{array}{c}\text { Emissions } \\
\text { Source }\end{array}$ & Factor Type & Amount & Units & Reference \\
\hline & $\begin{array}{l}\mathrm{N}_{2} \mathrm{O} \text { Emission } \\
\text { Factor }\end{array}$ & 0.0001 & $\begin{array}{l}\mathrm{kg} \mathrm{N}_{2} \mathrm{O} / \\
\mathrm{MMBtu}\end{array}$ & $\begin{array}{l}\text { EPA Mandatory Reporting Rule, } \\
40 \text { CFR 98, Table C-2 to Subpart C of } \\
\text { Part } 98 .\end{array}$ \\
\hline \multirow[t]{4}{*}{$\begin{array}{l}\text { Liquefied } \\
\text { Propane Gas } \\
\text { (LPG) }\end{array}$} & $\begin{array}{l}\text { HHV } \\
\text { Conversion } \\
\text { Factor } \\
\end{array}$ & 0.092 & MMBtu/gal & $\begin{array}{l}\text { EPA Mandatory Reporting Rule, } \\
40 \text { CFR 98, Table C-1 to Subpart C of } \\
\text { Part } 98 .\end{array}$ \\
\hline & $\begin{array}{l}\mathrm{CO}_{2} \text { Emission } \\
\text { Factor }\end{array}$ & 62.98 & $\begin{array}{l}\mathrm{kg} \mathrm{CO}_{2} / \\
\mathrm{MMBtu}\end{array}$ & $\begin{array}{l}\text { EPA Mandatory Reporting Rule, } \\
40 \text { CFR 98, Table C-1 to Subpart C of } \\
\text { Part } 98 .\end{array}$ \\
\hline & $\begin{array}{l}\mathrm{CH}_{4} \text { Emission } \\
\text { Factor }\end{array}$ & 0.003 & $\begin{array}{l}\mathrm{kg} \mathrm{CH}_{4} / \\
\text { MMBtu }\end{array}$ & $\begin{array}{l}\text { EPA Mandatory Reporting Rule, } \\
40 \text { CFR 98, Table C-2 to Subpart C of } \\
\text { Part } 98 .\end{array}$ \\
\hline & $\begin{array}{l}\mathrm{N}_{2} \mathrm{O} \text { Emission } \\
\text { Factor }\end{array}$ & 0.0006 & $\begin{array}{l}\mathrm{kg} \mathrm{N}_{2} \mathrm{O} / \\
\mathrm{MMBtu}\end{array}$ & $\begin{array}{l}\text { EPA Mandatory Reporting Rule, } \\
40 \text { CFR 98, Table C-2 to Subpart C of } \\
\text { Part } 98 .\end{array}$ \\
\hline
\end{tabular}


Table D-2. Mobile combustion emissions factors used.

\begin{tabular}{|c|c|c|c|c|}
\hline Emissions Source & Factor Type & Amount & Units & Reference \\
\hline \multirow[t]{2}{*}{$\begin{array}{l}\text { Gasoline } \\
\text { (Considered "Motor } \\
\text { gasoline") }\end{array}$} & $\begin{array}{l}\text { HHV Conversion } \\
\text { Factor }\end{array}$ & 0.125 & $\begin{array}{l}\text { MMBtu/ } \\
\text { gal }\end{array}$ & $\begin{array}{l}\text { EPA Mandatory Reporting Rule, } 40 \\
\text { CFR 98, Table C-1 to Subpart C of } \\
\text { Part 98. }\end{array}$ \\
\hline & $\begin{array}{l}\mathrm{CO}_{2} \text { Emissions } \\
\text { Factor }\end{array}$ & 70.22 & $\begin{array}{l}\mathrm{kg} \mathrm{CO}_{2} / \\
\mathrm{MMBtu}\end{array}$ & $\begin{array}{l}\text { EPA Mandatory Reporting Rule, } 40 \\
\text { CFR 98, Table C-1 to Subpart C of } \\
\text { Part 98. }\end{array}$ \\
\hline \multirow[t]{2}{*}{$\begin{array}{l}\text { Gasoline, Bus } \\
\text { (Considered } \\
\text { "Gasoline Buses") }\end{array}$} & $\begin{array}{l}\mathrm{CH}_{4} \text { Emissions } \\
\text { Factor }\end{array}$ & 0.021 & $\begin{array}{l}\mathrm{g} \mathrm{CH}_{4} / \\
\text { mile }\end{array}$ & $\begin{array}{l}\text { Emission Factors from } \\
\text { Cross-Sector Tools, GHG Protocol, } \\
\text { http://www.ghgprotocol.org/ } \\
\text { calculation-tools/all-tools, v. 1.0, } \\
\text { July 2009. }\end{array}$ \\
\hline & $\begin{array}{l}\mathrm{N}_{2} \mathrm{O} \text { Emissions } \\
\text { Factor }\end{array}$ & 0.017 & $\begin{array}{l}\mathrm{g} \mathrm{N}_{2} \mathrm{O} / \\
\text { mile }\end{array}$ & $\begin{array}{l}\text { Emission Factors from } \\
\text { Cross-Sector Tools, GHG Protocol, } \\
\text { http://www.ghgprotocol.org/ } \\
\text { calculation-tools/all-tools, v. 1.0, } \\
\text { July 2009. }\end{array}$ \\
\hline \multirow{2}{*}{$\begin{array}{l}\text { Gasoline, Light-Duty } \\
\text { Car } \\
\text { (Considered } \\
\text { "Gasoline Passenger } \\
\text { Car," Tier } 1 \text { [1995- } \\
2000] \text { ) }\end{array}$} & $\begin{array}{l}\mathrm{CH}_{4} \text { Emissions } \\
\text { Factor }\end{array}$ & 0.0271 & $\begin{array}{l}\mathrm{g} \mathrm{CH}_{4} / \\
\text { mile }\end{array}$ & $\begin{array}{l}\text { Table A-1, EPA Climate Leaders, } \\
\text { Mobile Combustion Sources, EPA } \\
\text { 430-K-08-004, May } 2008 .\end{array}$ \\
\hline & $\begin{array}{l}\mathrm{N}_{2} \mathrm{O} \text { Emissions } \\
\text { Factor }\end{array}$ & 0.0429 & $\begin{array}{l}\mathrm{g} \mathrm{N}_{2} \mathrm{O} / \\
\text { mile }\end{array}$ & $\begin{array}{l}\text { Table A-1, EPA Climate Leaders, } \\
\text { Mobile Combustion Sources, EPA } \\
\text { 430-K-08-004, May } 2008 .\end{array}$ \\
\hline \multirow{2}{*}{$\begin{array}{l}\text { Gasoline, Light-Duty } \\
\text { Truck } \\
\text { (Considered } \\
\text { "Gasoline Light-Duty } \\
\text { Trucks," Tier 1 } \\
\text { [1995-2000]) }\end{array}$} & $\begin{array}{l}\mathrm{CH}_{4} \text { Emissions } \\
\text { Factor }\end{array}$ & 0.0452 & $\begin{array}{l}\mathrm{g} \mathrm{CH}_{4} / \\
\text { mile }\end{array}$ & $\begin{array}{l}\text { Table A-1, EPA Climate Leaders, } \\
\text { Mobile Combustion Sources, EPA } \\
\text { 430-K-08-004, May } 2008 .\end{array}$ \\
\hline & $\begin{array}{l}\mathrm{N}_{2} \mathrm{O} \text { Emissions } \\
\text { Factor }\end{array}$ & 0.0871 & $\begin{array}{l}\mathrm{g} \mathrm{N}_{2} \mathrm{O} / \\
\text { mile }\end{array}$ & $\begin{array}{l}\text { Table A-1, EPA Climate Leaders, } \\
\text { Mobile Combustion Sources, EPA } \\
\text { 430-K-08-004, May } 2008 .\end{array}$ \\
\hline \multirow{2}{*}{$\begin{array}{l}\text { Gasoline, Equipment } \\
\text { (Considered } \\
\text { "Gasoline } \\
\text { Construction } \\
\text { Equipment") }\end{array}$} & $\begin{array}{l}\mathrm{CH}_{4} \text { Emissions } \\
\text { Factor }\end{array}$ & 0.5 & $\mathrm{~g} \mathrm{CH}_{4} /$ gal & $\begin{array}{l}\text { Table A-6, EPA Climate Leaders, } \\
\text { Mobile Combustion Sources, EPA } \\
\text { 430-K-08-004, May } 2008 .\end{array}$ \\
\hline & $\begin{array}{l}\mathrm{N}_{2} \mathrm{O} \text { Emissions } \\
\text { Factor }\end{array}$ & 0.22 & $\mathrm{~g} \mathrm{~N}_{2} \mathrm{O} / \mathrm{gal}$ & $\begin{array}{l}\text { Table A-6, EPA Climate Leaders, } \\
\text { Mobile Combustion Sources, EPA } \\
\text { 430-K-08-004, May } 2008 .\end{array}$ \\
\hline \multirow{2}{*}{$\begin{array}{l}\text { Gasoline, Heavy } \\
\text { Duty } \\
\text { (Considered } \\
\text { "Gasoline } \\
\text { Heavy-Duty Trucks," } \\
\text { Tier 0) }\end{array}$} & $\begin{array}{l}\mathrm{CH}_{4} \text { Emissions } \\
\text { Factor }\end{array}$ & 0.0655 & $\begin{array}{l}\mathrm{g} \mathrm{CH}_{4} / \\
\text { mile }\end{array}$ & $\begin{array}{l}\text { Table A-1, EPA Climate Leaders, } \\
\text { Mobile Combustion Sources, EPA } \\
\text { 430-K-08-004, May } 2008 .\end{array}$ \\
\hline & $\begin{array}{l}\mathrm{N}_{2} \mathrm{O} \text { Emissions } \\
\text { Factor }\end{array}$ & 0.175 & $\begin{array}{l}\mathrm{g} \mathrm{N}_{2} \mathrm{O} / \\
\text { mile }\end{array}$ & $\begin{array}{l}\text { Table A-1, EPA Climate Leaders, } \\
\text { Mobile Combustion Sources, EPA } \\
\text { 430-K-08-004, May } 2008 .\end{array}$ \\
\hline
\end{tabular}


Table D-2. (continued).

\begin{tabular}{|c|c|c|c|c|}
\hline Emissions Source & Factor Type & Amount & Units & Reference \\
\hline \multirow[t]{2}{*}{$\begin{array}{l}\text { LNG } \\
\text { (Considered "Natural } \\
\text { Gasoline") }\end{array}$} & $\begin{array}{l}\text { HHV Conversion } \\
\text { Factor }\end{array}$ & 0.110 & $\begin{array}{l}\text { MMBtu/ } \\
\text { gal }\end{array}$ & $\begin{array}{l}\text { EPA Mandatory Reporting Rule, } 40 \\
\text { CFR 98, Table C-1 to Subpart C of } \\
\text { Part 98. }\end{array}$ \\
\hline & $\begin{array}{l}\mathrm{CO}_{2} \text { Emission } \\
\text { Factor }\end{array}$ & 66.83 & $\begin{array}{l}\mathrm{kg} \mathrm{CO}_{2} / \\
\mathrm{MMBtu}\end{array}$ & $\begin{array}{l}\text { EPA Mandatory Reporting Rule, } 40 \\
\text { CFR 98, Table C-1 to Subpart C of } \\
\text { Part 98. }\end{array}$ \\
\hline \multirow[t]{2}{*}{$\begin{array}{l}\text { LNG, Bus } \\
\text { (Considered "CNG } \\
\text { Buses") }\end{array}$} & $\begin{array}{l}\mathrm{CH}_{4} \text { Emissions } \\
\text { Factor }\end{array}$ & 1.966 & $\begin{array}{l}\mathrm{g} \mathrm{CH}_{4} / \\
\text { mile }\end{array}$ & $\begin{array}{l}\text { Table A-7, EPA Climate Leaders, } \\
\text { Mobile Combustion Sources, EPA } \\
\text { 430-K-08-004, May } 2008 .\end{array}$ \\
\hline & $\begin{array}{l}\mathrm{N}_{2} \mathrm{O} \text { Emissions } \\
\text { Factor }\end{array}$ & 0.175 & $\begin{array}{l}\mathrm{g} \mathrm{N}_{2} \mathrm{O} / \\
\text { mile }\end{array}$ & $\begin{array}{l}\text { Table A-7, EPA Climate Leaders, } \\
\text { Mobile Combustion Sources, EPA } \\
\text { 430-K-08-004, May } 2008 .\end{array}$ \\
\hline \multirow{2}{*}{$\begin{array}{l}\text { LNG, Equipment } \\
\text { (Considered "LNG } \\
\text { Heavy-Duty } \\
\text { Vehicles") }\end{array}$} & $\begin{array}{l}\mathrm{CH}_{4} \text { Emissions } \\
\text { Factor }\end{array}$ & 1.966 & $\begin{array}{l}\mathrm{g} \mathrm{CH}_{4} / \\
\text { mile }\end{array}$ & $\begin{array}{l}\text { Table A-7, EPA Climate Leaders, } \\
\text { Mobile Combustion Sources, EPA } \\
\text { 430-K-08-004, May } 2008 .\end{array}$ \\
\hline & $\begin{array}{l}\mathrm{N}_{2} \mathrm{O} \text { Emissions } \\
\text { Factor }\end{array}$ & 0.175 & $\begin{array}{l}\mathrm{g} \mathrm{N}_{2} \mathrm{O} / \\
\text { mile }\end{array}$ & $\begin{array}{l}\text { Table A-7, EPA Climate Leaders, } \\
\text { Mobile Combustion Sources, EPA } \\
\text { 430-K-08-004, May } 2008 .\end{array}$ \\
\hline \multirow{2}{*}{$\begin{array}{l}\text { Diesel } \\
\text { (Considered } \\
\text { "Distillate Fuel Oil } \\
\text { No. 2") }\end{array}$} & $\begin{array}{l}\text { HHV Conversion } \\
\text { Factor }\end{array}$ & 0.138 & $\begin{array}{l}\text { MMBtu/ } \\
\text { gal }\end{array}$ & $\begin{array}{l}\text { EPA Mandatory Reporting Rule, } 40 \\
\text { CFR 98, Table C-1 to Subpart C of } \\
\text { Part } 98 .\end{array}$ \\
\hline & $\begin{array}{l}\mathrm{CO}_{2} \text { Emissions } \\
\text { Factor }\end{array}$ & 73.96 & $\begin{array}{l}\mathrm{kg} \mathrm{CO}_{2} / \\
\mathrm{MMBtu}\end{array}$ & $\begin{array}{l}\text { EPA Mandatory Reporting Rule, } 40 \\
\text { CFR 98, Table C-1 to Subpart C of } \\
\text { Part 98. }\end{array}$ \\
\hline \multirow[t]{2}{*}{$\begin{array}{l}\text { Diesel, Bus } \\
\text { (Considered “Diesel } \\
\text { Heavy-Duty Trucks") }\end{array}$} & $\begin{array}{l}\mathrm{CH}_{4} \text { Emissions } \\
\text { Factor }\end{array}$ & 0.0051 & $\begin{array}{l}\mathrm{g} \mathrm{CH}_{4} / \\
\text { mile }\end{array}$ & $\begin{array}{l}\text { Table A-1, EPA Climate Leaders, } \\
\text { Mobile Combustion Sources, EPA } \\
\text { 430-K-08-004, May } 2008 .\end{array}$ \\
\hline & $\begin{array}{l}\mathrm{N}_{2} \mathrm{O} \text { Emissions } \\
\text { Factor }\end{array}$ & 0.0048 & $\begin{array}{l}\mathrm{g} \mathrm{N}_{2} \mathrm{O} / \\
\text { mile }\end{array}$ & $\begin{array}{l}\text { Table A-1, EPA Climate Leaders, } \\
\text { Mobile Combustion Sources, EPA } \\
\text { 430-K-08-004, May } 2008 .\end{array}$ \\
\hline \multirow{2}{*}{$\begin{array}{l}\text { Diesel, Light-Duty } \\
\text { Truck } \\
\text { (Considered “Diesel } \\
\text { Light Trucks," } \\
\text { Moderate) }\end{array}$} & $\begin{array}{l}\mathrm{CH}_{4} \text { Emissions } \\
\text { Factor }\end{array}$ & 0.0009 & $\begin{array}{l}\mathrm{g} \mathrm{CH}_{4} / \\
\text { mile }\end{array}$ & $\begin{array}{l}\text { Table A-1, EPA Climate Leaders, } \\
\text { Mobile Combustion Sources, EPA } \\
\text { 430-K-08-004, May } 2008 .\end{array}$ \\
\hline & $\begin{array}{l}\mathrm{N}_{2} \mathrm{O} \text { Emissions } \\
\text { Factor }\end{array}$ & 0.0014 & $\begin{array}{l}\mathrm{g} \mathrm{N}_{2} \mathrm{O} / \\
\text { mile }\end{array}$ & $\begin{array}{l}\text { Table A-1, EPA Climate Leaders, } \\
\text { Mobile Combustion Sources, EPA } \\
\text { 430-K-08-004, May } 2008 .\end{array}$ \\
\hline \multirow[t]{2}{*}{$\begin{array}{l}\text { Diesel, Heavy Duty } \\
\text { (Considered "Diesel } \\
\text { Heavy-Duty Trucks") }\end{array}$} & $\begin{array}{l}\mathrm{CH}_{4} \text { Emissions } \\
\text { Factor }\end{array}$ & 0.0051 & $\begin{array}{l}\mathrm{g} \mathrm{CH}_{4} / \\
\text { mile }\end{array}$ & $\begin{array}{l}\text { Table A-1, EPA Climate Leaders, } \\
\text { Mobile Combustion Sources, EPA } \\
\text { 430-K-08-004, May } 2008 .\end{array}$ \\
\hline & $\begin{array}{l}\mathrm{N}_{2} \mathrm{O} \text { Emissions } \\
\text { Factor }\end{array}$ & 0.0048 & $\begin{array}{l}\mathrm{g} \mathrm{N}_{2} \mathrm{O} / \\
\text { mile }\end{array}$ & $\begin{array}{l}\text { Table A-1, EPA Climate Leaders, } \\
\text { Mobile Combustion Sources, EPA } \\
\text { 430-K-08-004, May } 2008 .\end{array}$ \\
\hline
\end{tabular}


Table D-2. (continued).

\begin{tabular}{|c|c|c|c|c|}
\hline Emissions Source & Factor Type & Amount & Units & Reference \\
\hline \multirow{2}{*}{$\begin{array}{l}\text { Diesel, Equipment } \\
\text { (Considered "Diesel } \\
\text { Construction } \\
\text { Equipment") }\end{array}$} & $\begin{array}{l}\mathrm{CH}_{4} \text { Emissions } \\
\text { Factor }\end{array}$ & 0.58 & $\mathrm{~g} \mathrm{CH}_{4} / \mathrm{gal}$ & $\begin{array}{l}\text { Table A-6, EPA Climate Leaders, } \\
\text { Mobile Combustion Sources, EPA } \\
\text { 430-K-08-004, May } 2008 .\end{array}$ \\
\hline & $\begin{array}{l}\mathrm{N}_{2} \mathrm{O} \text { Emissions } \\
\text { Factor }\end{array}$ & 0.26 & $\mathrm{~g} \mathrm{~N}_{2} \mathrm{O} /$ gal & $\begin{array}{l}\text { Table A-6, EPA Climate Leaders, } \\
\text { Mobile Combustion Sources, EPA } \\
\text { 430-K-08-004, May } 2008 .\end{array}$ \\
\hline \multirow[t]{2}{*}{$\begin{array}{l}\text { Biodiesel } \\
\text { (Considered } \\
\text { "Biodiesel [100\%]") }\end{array}$} & $\begin{array}{l}\text { HHV Conversion } \\
\text { Factor }\end{array}$ & 0.128 & $\begin{array}{l}\text { MMBtu/ } \\
\text { gal }\end{array}$ & $\begin{array}{l}\text { EPA Mandatory Reporting Rule, } 40 \\
\text { CFR 98, Table C-1 to Subpart C of } \\
\text { Part } 98 .\end{array}$ \\
\hline & $\begin{array}{l}\mathrm{CO}_{2} \text { Emissions } \\
\text { Factor }\end{array}$ & 73.84 & $\begin{array}{l}\mathrm{kg} \mathrm{CO}_{2} / \\
\mathrm{MMBtu}\end{array}$ & $\begin{array}{l}\text { EPA Mandatory Reporting Rule, } 40 \\
\text { CFR 98, Table C-1 to Subpart C of } \\
\text { Part } 98 \text {. }\end{array}$ \\
\hline \multirow[t]{2}{*}{$\begin{array}{l}\text { Biodiesel, Bus } \\
\text { (Considered "Diesel } \\
\text { Heavy-Duty Trucks") }\end{array}$} & $\begin{array}{l}\mathrm{CH}_{4} \text { Emissions } \\
\text { Factor }\end{array}$ & 0.0051 & $\begin{array}{l}\mathrm{g} \mathrm{CH}_{4} / \\
\text { mile }\end{array}$ & $\begin{array}{l}\text { Table A-1, EPA Climate Leaders, } \\
\text { Mobile Combustion Sources, EPA } \\
\text { 430-K-08-004, May } 2008 .\end{array}$ \\
\hline & $\begin{array}{l}\mathrm{N}_{2} \mathrm{O} \text { Emissions } \\
\text { Factor }\end{array}$ & 0.0048 & $\begin{array}{l}\mathrm{g} \mathrm{N}_{2} \mathrm{O} / \\
\text { mile }\end{array}$ & $\begin{array}{l}\text { Table A-1, EPA Climate Leaders, } \\
\text { Mobile Combustion Sources, EPA } \\
\text { 430-K-08-004, May } 2008 .\end{array}$ \\
\hline \multirow{2}{*}{$\begin{array}{l}\text { Biodiesel, Equipment } \\
\text { (Considered "Diesel } \\
\text { Construction } \\
\text { Equipment") }\end{array}$} & $\begin{array}{l}\mathrm{CH}_{4} \text { Emissions } \\
\text { Factor }\end{array}$ & 0.58 & $\mathrm{~g} \mathrm{CH}_{4} /$ gal & $\begin{array}{l}\text { Table A-6, EPA Climate Leaders, } \\
\text { Mobile Combustion Sources, EPA } \\
\text { 430-K-08-004, May } 2008 .\end{array}$ \\
\hline & $\begin{array}{l}\mathrm{N}_{2} \mathrm{O} \text { Emissions } \\
\text { Factor }\end{array}$ & 0.26 & $\mathrm{~g} \mathrm{~N}_{2} \mathrm{O} / \mathrm{gal}$ & $\begin{array}{l}\text { Table A-6, EPA Climate Leaders, } \\
\text { Mobile Combustion Sources, EPA } \\
\text { 430-K-08-004, May } 2008 .\end{array}$ \\
\hline \multirow{2}{*}{$\begin{array}{l}\text { Biodiesel, Light-Duty } \\
\text { Truck } \\
\text { (Considered "Diesel } \\
\text { Light Trucks," } \\
\text { Moderate) }\end{array}$} & $\begin{array}{l}\mathrm{CH}_{4} \text { Emissions } \\
\text { Factor }\end{array}$ & 0.0009 & $\begin{array}{l}\mathrm{g} \mathrm{CH}_{4} / \\
\text { mile }\end{array}$ & $\begin{array}{l}\text { Table A-1, EPA Climate Leaders, } \\
\text { Mobile Combustion Sources, EPA } \\
\text { 430-K-08-004, May } 2008 .\end{array}$ \\
\hline & $\begin{array}{l}\mathrm{N}_{2} \mathrm{O} \text { Emissions } \\
\text { Factor }\end{array}$ & 0.0014 & $\begin{array}{l}\mathrm{g} \mathrm{N}_{2} \mathrm{O} / \\
\text { mile }\end{array}$ & $\begin{array}{l}\text { Table A-1, EPA Climate Leaders, } \\
\text { Mobile Combustion Sources, EPA } \\
\text { 430-K-08-004, May } 2008 .\end{array}$ \\
\hline \multirow{2}{*}{$\begin{array}{l}\text { Biodiesel, } \\
\text { Heavy-Duty } \\
\text { (Considered "Diesel } \\
\text { Heavy-Duty } \\
\text { Vehicles") }\end{array}$} & $\begin{array}{l}\mathrm{CH}_{4} \text { Emissions } \\
\text { Factor }\end{array}$ & 0.0051 & $\begin{array}{l}\mathrm{g} \mathrm{CH}_{4} / \\
\text { mile }\end{array}$ & $\begin{array}{l}\text { Table A-1, EPA Climate Leaders, } \\
\text { Mobile Combustion Sources, EPA } \\
\text { 430-K-08-004, May } 2008 .\end{array}$ \\
\hline & $\begin{array}{l}\mathrm{N}_{2} \mathrm{O} \text { Emissions } \\
\text { Factor }\end{array}$ & 0.0048 & $\begin{array}{l}\mathrm{g} \mathrm{N}_{2} \mathrm{O} / \\
\text { mile }\end{array}$ & $\begin{array}{l}\text { Table A-1, EPA Climate Leaders, } \\
\text { Mobile Combustion Sources, EPA } \\
\text { 430-K-08-004, May } 2008 .\end{array}$ \\
\hline \multirow[t]{2}{*}{$\begin{array}{l}\text { Ethanol } \\
\text { (Considered "Ethanol } \\
[100 \%] ")\end{array}$} & $\begin{array}{l}\text { HHV Conversion } \\
\text { Factor }\end{array}$ & 0.084 & $\begin{array}{l}\text { MMBtu/ } \\
\text { gal }\end{array}$ & $\begin{array}{l}\text { EPA Mandatory Reporting Rule, } 40 \\
\text { CFR 98, Table C-1 to Subpart C of } \\
\text { Part 98. }\end{array}$ \\
\hline & $\begin{array}{l}\mathrm{CO}_{2} \text { Emissions } \\
\text { Factor }\end{array}$ & 68.44 & $\begin{array}{l}\mathrm{kg} \mathrm{CO}_{2} / \\
\mathrm{MMBtu}\end{array}$ & $\begin{array}{l}\text { EPA Mandatory Reporting Rule, } 40 \\
\text { CFR 98, Table C-1 to Subpart C of } \\
\text { Part } 98 .\end{array}$ \\
\hline
\end{tabular}


Table D-2. (continued).

\begin{tabular}{|c|c|c|c|c|}
\hline Emissions Source & Factor Type & Amount & Units & Reference \\
\hline \multirow[t]{2}{*}{$\begin{array}{l}\text { Ethanol, Bus } \\
\text { (Considered "Ethanol } \\
\text { Buses") }\end{array}$} & $\begin{array}{l}\mathrm{CH}_{4} \text { Emissions } \\
\text { Factor }\end{array}$ & 0.197 & $\begin{array}{l}\mathrm{g} \mathrm{CH}_{4} / \\
\text { mile }\end{array}$ & $\begin{array}{l}\text { Table A-7, EPA Climate Leaders, } \\
\text { Mobile Combustion Sources, EPA } \\
\text { 430-K-08-004, May } 2008 .\end{array}$ \\
\hline & $\begin{array}{l}\mathrm{N}_{2} \mathrm{O} \text { Emissions } \\
\text { Factor }\end{array}$ & 0.175 & $\begin{array}{l}\mathrm{g} \mathrm{N}_{2} \mathrm{O} / \\
\text { mile }\end{array}$ & $\begin{array}{l}\text { Table A-7, EPA Climate Leaders, } \\
\text { Mobile Combustion Sources, EPA } \\
\text { 430-K-08-004, May } 2008 .\end{array}$ \\
\hline \multirow{2}{*}{$\begin{array}{l}\text { Ethanol, Equipment } \\
\text { and Heavy Duty } \\
\text { (Considered "Ethanol } \\
\text { Heavy-Duty } \\
\text { Vehicles") }\end{array}$} & $\begin{array}{l}\mathrm{CH}_{4} \text { Emissions } \\
\text { Factor }\end{array}$ & 0.197 & $\begin{array}{l}\mathrm{g} \mathrm{CH}_{4} / \\
\text { mile }\end{array}$ & $\begin{array}{l}\text { Table A-7, EPA Climate Leaders, } \\
\text { Mobile Combustion Sources, EPA } \\
\text { 430-K-08-004, May } 2008 .\end{array}$ \\
\hline & $\begin{array}{l}\mathrm{N}_{2} \mathrm{O} \text { Emissions } \\
\text { Factor }\end{array}$ & 0.175 & $\begin{array}{l}\mathrm{g} \mathrm{N}_{2} \mathrm{O} / \\
\text { mile }\end{array}$ & $\begin{array}{l}\text { Table A-7, EPA Climate Leaders, } \\
\text { Mobile Combustion Sources, EPA } \\
\text { 430-K-08-004, May } 2008 \text {. }\end{array}$ \\
\hline \multirow{2}{*}{$\begin{array}{l}\text { Ethanol, Light-Duty } \\
\text { Car and Truck } \\
\text { (Considered "Ethanol } \\
\text { Light-Duty } \\
\text { Vehicles") }\end{array}$} & $\begin{array}{l}\mathrm{CH}_{4} \text { Emissions } \\
\text { Factor }\end{array}$ & 0.055 & $\begin{array}{l}\mathrm{g} \mathrm{CH}_{4} / \\
\text { mile }\end{array}$ & $\begin{array}{l}\text { Table A-7, EPA Climate Leaders, } \\
\text { Mobile Combustion Sources, EPA } \\
\text { 430-K-08-004, May } 2008 .\end{array}$ \\
\hline & $\begin{array}{l}\mathrm{N}_{2} \mathrm{O} \text { Emissions } \\
\text { Factor }\end{array}$ & 0.067 & $\begin{array}{l}\mathrm{g} \mathrm{N}_{2} \mathrm{O} / \\
\text { mile }\end{array}$ & $\begin{array}{l}\text { Table A-7, EPA Climate Leaders, } \\
\text { Mobile Combustion Sources, EPA } \\
\text { 430-K-08-004, May } 2008 .\end{array}$ \\
\hline
\end{tabular}

Fugitive emissions are based directly on the GWP of the various gases emitted, so no additional table is provided from Table 8 that was shown previously in the main body. 


\section{D-2. SCOPE TWO - INDIRECT EMISSIONS}

Table D-3. Electricity emissions factors used.

\begin{tabular}{|c|c|c|c|c|}
\hline Emissions Source & Factor Type & Amount & Units & Reference \\
\hline \multirow{3}{*}{$\begin{array}{l}\text { INL Site Electricity } \\
\text { Purchase (and T\&D } \\
\text { loss) } \\
\text { (Considered NWPP of } \\
\text { "WECC" eGRID } \\
\text { Subregion) }\end{array}$} & $\begin{array}{l}\mathrm{CO}_{2} \text { Emissions } \\
\text { Factor }\end{array}$ & 371.588 & $\begin{array}{l}\mathrm{kg} \mathrm{CO}_{2} / \\
\mathrm{MWh}\end{array}$ & $\begin{array}{l}\text { EPA, eGRID } 2012 \text { Version } 1.0 \\
\text { Year } 2009 \text { Summary Tables, p.3, } \\
\text { "Output Emission Rates." }\end{array}$ \\
\hline & $\begin{array}{l}\mathrm{CH}_{4} \text { Emissions } \\
\text { Factor }\end{array}$ & 6.935 & $\begin{array}{l}\mathrm{kg} \mathrm{CH} / \\
\text { GWh }\end{array}$ & $\begin{array}{l}\text { EPA, eGRID } 2012 \text { Version } 1.0 \\
\text { Year } 2009 \text { Summary Tables, p.3, } \\
\text { "Output Emission Rates." }\end{array}$ \\
\hline & $\begin{array}{l}\mathrm{N}_{2} \mathrm{O} \text { Emissions } \\
\text { Factor }\end{array}$ & 5.670 & $\begin{array}{l}\mathrm{kg} \mathrm{N}_{2} \mathrm{O} / \\
\mathrm{GWh}\end{array}$ & $\begin{array}{l}\text { EPA, eGRID } 2012 \text { Version } 1.0 \\
\text { Year } 2009 \text { Summary Tables, p.3, } \\
\text { "Output Emission Rates." }\end{array}$ \\
\hline \multirow[t]{3}{*}{$\begin{array}{l}\text { FY12 RECs Purchase } \\
\text { (Considered NWPP of } \\
\text { "WECC" eGRID } \\
\text { Subregion) }\end{array}$} & $\begin{array}{l}\mathrm{CO}_{2} \text { Emissions } \\
\text { Factor }\end{array}$ & 637.094 & $\begin{array}{l}\mathrm{kg} \mathrm{CO}_{2} / \\
\mathrm{MWh}\end{array}$ & $\begin{array}{l}\text { EPA, eGRID } 2012 \text { Version } 1.0 \\
\text { Year } 2009 \text { Summary Tables, p. 3, } \\
\text { "Non-baseload Output Emission } \\
\text { Rates." }\end{array}$ \\
\hline & $\begin{array}{l}\mathrm{CH}_{4} \text { Emissions } \\
\text { Factor }\end{array}$ & 17.491 & $\begin{array}{l}\mathrm{kg} \mathrm{CH}_{4} / \\
\mathrm{GWh}\end{array}$ & $\begin{array}{l}\text { EPA, eGRID } 2012 \text { Version } 1.0 \\
\text { Year } 2009 \text { Summary Tables, p. 3, } \\
\text { "Non-baseload Output Emission } \\
\text { Rates." }\end{array}$ \\
\hline & $\begin{array}{l}\mathrm{N}_{2} \mathrm{O} \text { Emissions } \\
\text { Factor }\end{array}$ & 8.523 & $\begin{array}{l}\mathrm{kg} \mathrm{N}_{2} \mathrm{O} / \\
\mathrm{GWh}\end{array}$ & $\begin{array}{l}\text { EPA, eGRID } 2012 \text { Version } 1.0 \\
\text { Year } 2009 \text { Summary Tables, p. 3, } \\
\text { "Non-baseload Output Emission } \\
\text { Rates." }\end{array}$ \\
\hline
\end{tabular}




\section{D-3. SCOPE THREE - INDIRECT EMISSIONS}

Table D-4. Employee commute, rental car miles, and personal car miles emissions factors used.

\begin{tabular}{|c|c|c|c|c|}
\hline Emissions Source & Factor Type & Amount & Units & Reference \\
\hline \multirow[t]{3}{*}{ Passenger Cars } & $\begin{array}{l}\mathrm{CO}_{2} \text { Emissions } \\
\text { Factor }\end{array}$ & 0.364 & $\begin{array}{l}\mathrm{kg} \mathrm{CO}_{2} / \\
\text { vehicle-mile }\end{array}$ & $\begin{array}{l}\text { Table 5, EPA Climate Leaders, } \\
\text { Commuting, Business Travel \& } \\
\text { Mobile Transport, EPA } \\
\text { 430-R-08-006, May } 2008 .\end{array}$ \\
\hline & $\begin{array}{l}\mathrm{CH}_{4} \text { Emissions } \\
\text { Factor }\end{array}$ & $0.031 \times 10^{-3}$ & $\begin{array}{l}\mathrm{kg} \mathrm{CH}_{4} / \\
\text { vehicle-mile }\end{array}$ & $\begin{array}{l}\text { Table 5, EPA Climate Leaders, } \\
\text { Commuting, Business Travel \& } \\
\text { Mobile Transport, EPA } \\
\text { 430-R-08-006, May } 2008 .\end{array}$ \\
\hline & $\begin{array}{l}\mathrm{N}_{2} \mathrm{O} \text { Emissions } \\
\text { Factor }\end{array}$ & $0.032 \times 10^{-3}$ & $\begin{array}{l}\mathrm{kg} \mathrm{N} \mathrm{N}_{2} \mathrm{O} / \\
\text { vehicle-mile }\end{array}$ & $\begin{array}{l}\text { Table 5, EPA Climate Leaders, } \\
\text { Commuting, Business Travel \& } \\
\text { Mobile Transport, EPA } \\
\text { 430-R-08-006, May } 2008 .\end{array}$ \\
\hline \multirow[t]{3}{*}{$\begin{array}{l}\text { Light-Duty } \\
\text { Truck/Van/SUV }\end{array}$} & $\begin{array}{l}\mathrm{CO}_{2} \text { Emissions } \\
\text { Factor }\end{array}$ & 0.519 & $\begin{array}{l}\mathrm{kg} \mathrm{CO}_{2} / \\
\text { vehicle-mile }\end{array}$ & $\begin{array}{l}\text { Table 5, EPA Climate Leaders, } \\
\text { Commuting, Business Travel \& } \\
\text { Mobile Transport, EPA } \\
\text { 430-R-08-006, May } 2008 .\end{array}$ \\
\hline & $\begin{array}{l}\mathrm{CH}_{4} \text { Emissions } \\
\text { Factor }\end{array}$ & $0.036 \times 10^{-3}$ & $\begin{array}{l}\mathrm{kg} \mathrm{CH}_{4} / \\
\text { vehicle-mile }\end{array}$ & $\begin{array}{l}\text { Table 5, EPA Climate Leaders, } \\
\text { Commuting, Business Travel \& } \\
\text { Mobile Transport, EPA } \\
\text { 430-R-08-006, May } 2008 .\end{array}$ \\
\hline & $\begin{array}{l}\mathrm{N}_{2} \mathrm{O} \text { Emissions } \\
\text { Factor }\end{array}$ & $0.047 \times 10^{-3}$ & $\begin{array}{l}\mathrm{kg} \mathrm{N}_{2} \mathrm{O} / \\
\text { vehicle-mile }\end{array}$ & $\begin{array}{l}\text { Table 5, EPA Climate Leaders, } \\
\text { Commuting, Business Travel \& } \\
\text { Mobile Transport, EPA } \\
\text { 430-R-08-006, May } 2008 .\end{array}$ \\
\hline
\end{tabular}


Table D-5. Business travel airline miles emissions factors used.

\begin{tabular}{|c|c|c|c|c|}
\hline $\begin{array}{c}\text { Emissions } \\
\text { Source }\end{array}$ & $\begin{array}{c}\text { Factor } \\
\text { Type }\end{array}$ & Amount & Units & Reference \\
\hline \multirow{3}{*}{$\begin{array}{l}\text { Airline } \\
\text { Miles, } \\
\text { Short Haul } \\
(<300 \\
\text { miles })\end{array}$} & $\begin{array}{l}\mathrm{CO}_{2} \\
\text { Emissions } \\
\text { Factor }\end{array}$ & 0.28967 & $\begin{array}{l}\mathrm{kg} \mathrm{CO}_{2} / \\
\text { passenger-mile }\end{array}$ & $\begin{array}{l}2012 \text { Guidelines to Defra/DECC's GHG } \\
\text { Conversion Factors for Company Reporting. } \\
\text { http://www.defra.gov.uk/publications/files/pb } \\
\text { 13773-ghg-conversion-factors-2012.pdf }\end{array}$ \\
\hline & $\begin{array}{l}\mathrm{CH}_{4} \\
\text { Emissions } \\
\text { Factor }\end{array}$ & $8.35 \times 10^{-6}$ & $\begin{array}{l}\mathrm{g} \mathrm{CH}_{4} / \\
\text { passenger-mile }\end{array}$ & $\begin{array}{l}2012 \text { Guidelines to Defra/DECC's GHG } \\
\text { Conversion Factors for Company Reporting. } \\
\text { http://www.defra.gov.uk/publications/files/pb } \\
\text { 13773-ghg-conversion-factors-2012.pdf }\end{array}$ \\
\hline & $\begin{array}{l}\mathrm{N}_{2} \mathrm{O} \\
\text { Emissions } \\
\text { Factor }\end{array}$ & $9.22 \times 10^{-6}$ & $\begin{array}{l}\mathrm{g} \mathrm{N}_{2} \mathrm{O} / \\
\text { passenger-mile }\end{array}$ & $\begin{array}{l}2012 \text { Guidelines to Defra/DECC's GHG } \\
\text { Conversion Factors for Company Reporting. } \\
\text { http://www.defra.gov.uk/publications/files/pb } \\
\text { 13773-ghg-conversion-factors-2012.pdf }\end{array}$ \\
\hline \multirow{3}{*}{$\begin{array}{l}\text { Airline } \\
\text { Miles, } \\
\text { Medium } \\
\text { Haul } \\
(300-700 \\
\text { miles) }\end{array}$} & $\begin{array}{l}\mathrm{CO}_{2} \\
\text { Emissions } \\
\text { Factor }\end{array}$ & 0.1654 & $\begin{array}{l}\mathrm{kg} \mathrm{CO}_{2} / \\
\text { passenger-mile }\end{array}$ & $\begin{array}{l}2012 \text { Guidelines to Defra/DECC's GHG } \\
\text { Conversion Factors for Company Reporting. } \\
\text { http://www.defra.gov.uk/publications/files/pb } \\
\text { 13773-ghg-conversion-factors-2012.pdf }\end{array}$ \\
\hline & $\begin{array}{l}\mathrm{CH}_{4} \\
\text { Emissions } \\
\text { Factor }\end{array}$ & $8.35 \times 10^{-7}$ & $\begin{array}{l}\mathrm{g} \mathrm{CH}_{4} / \\
\text { passenger-mile }\end{array}$ & $\begin{array}{l}2012 \text { Guidelines to Defra/DECC's GHG } \\
\text { Conversion Factors for Company Reporting. } \\
\text { http://www.defra.gov.uk/publications/files/pb } \\
\text { 13773-ghg-conversion-factors-2012.pdf }\end{array}$ \\
\hline & $\begin{array}{l}\mathrm{N}_{2} \mathrm{O} \\
\text { Emissions } \\
\text { Factor }\end{array}$ & $5.26 \times 10^{-6}$ & $\begin{array}{l}\mathrm{g} \mathrm{N}_{2} \mathrm{O} / \\
\text { passenger-mile }\end{array}$ & $\begin{array}{l}2012 \text { Guidelines to Defra/DECC's GHG } \\
\text { Conversion Factors for Company Reporting. } \\
\text { http://www.defra.gov.uk/publications/files/pb } \\
\text { 13773-ghg-conversion-factors-2012.pdf }\end{array}$ \\
\hline \multirow{3}{*}{$\begin{array}{l}\text { Airline } \\
\text { Miles, } \\
\text { Long Haul } \\
(\geq 700 \\
\text { miles) }\end{array}$} & $\begin{array}{l}\mathrm{CO}_{2} \\
\text { Emissions } \\
\text { Factor }\end{array}$ & 0.18936 & $\begin{array}{l}\mathrm{kg} \mathrm{CO}_{2} / \\
\text { passenger-mile }\end{array}$ & $\begin{array}{l}2012 \text { Guidelines to Defra/DECC's GHG } \\
\text { Conversion Factors for Company Reporting. } \\
\text { http://www.defra.gov.uk/publications/files/pb } \\
\text { 13773-ghg-conversion-factors-2012.pdf }\end{array}$ \\
\hline & $\begin{array}{l}\mathrm{CH}_{4} \\
\text { Emissions } \\
\text { Factor }\end{array}$ & $8.35 \times 10^{-7}$ & $\begin{array}{l}\mathrm{g} \mathrm{CH}_{4} / \\
\text { passenger-mile }\end{array}$ & $\begin{array}{l}2012 \text { Guidelines to Defra/DECC's GHG } \\
\text { Conversion Factors for Company Reporting. } \\
\text { http://www.defra.gov.uk/publications/files/pb } \\
\text { 13773-ghg-conversion-factors-2012.pdf }\end{array}$ \\
\hline & $\begin{array}{l}\mathrm{N}_{2} \mathrm{O} \\
\text { Emissions } \\
\text { Factor }\end{array}$ & $6 \times 10^{-6}$ & $\begin{array}{l}\mathrm{g} \mathrm{N}_{2} \mathrm{O} / \\
\text { passenger-mile }\end{array}$ & $\begin{array}{l}2012 \text { Guidelines to Defra/DECC's GHG } \\
\text { Conversion Factors for Company Reporting. } \\
\text { http://www.defra.gov.uk/publications/files/pb } \\
\text { 13773-ghg-conversion-factors-2012.pdf }\end{array}$ \\
\hline
\end{tabular}




\section{Appendix E}

\section{Scope 2 Comprehensive Tables}




\section{Appendix E}

\section{Scope 2 Comprehensive Tables}

Table E-1. INL's GHG emissions from electricity and RECs purchased in FY08-FY12.

\begin{tabular}{|l|r|r|r|r|r|}
\hline Emissions Category & $\begin{array}{c}\mathrm{FY08} \mathrm{GHG} \\
\text { Emissions } \\
\left(\mathrm{MT} \mathrm{CO}_{2} \mathrm{e}\right)\end{array}$ & $\begin{array}{c}\mathrm{FY09} \mathrm{GHG} \\
\text { Emissions } \\
\left(\mathrm{MT} \mathrm{CO}_{2} \mathrm{e}\right)\end{array}$ & $\begin{array}{c}\mathrm{FY} 10 \mathrm{GHG} \\
\text { Emissions } \\
\left(\mathrm{MT} \mathrm{CO}_{2} \mathrm{e}\right)\end{array}$ & $\begin{array}{c}\mathrm{FY} 11 \mathrm{GHG} \\
\text { Emissions } \\
\left(\mathrm{MT} \mathrm{CO}_{2} \mathrm{e}\right)\end{array}$ & $\begin{array}{c}\mathrm{FY} 12 \mathrm{GHG} \\
\text { Emissions } \\
\left(\mathrm{MT} \mathrm{CO}_{2} \mathrm{e}\right)\end{array}$ \\
\hline $\begin{array}{l}\text { Purchased Electricity } \\
\text { (includes T\&D losses } \\
\text { within INL's } \\
\text { operational controls) }\end{array}$ & 63,278 & 59,747 & 62,834 & 58,080 & 56,545 \\
\hline $\begin{array}{l}\text { Purchased RECs } \\
\text { (displaced GHG } \\
\text { emissions) }\end{array}$ & $-3,474$ & $-6,813$ & $-11,480$ & $-15,332$ & $-14,082$ \\
\hline \multicolumn{1}{|c|}{ SCOPE 2 TOTAL } & 59,804 & 52,934 & 51,354 & 42,748 & 42,463 \\
\hline
\end{tabular}


Appendix F

Receipt for RECs Purchased in FY12 


\title{
Appendix F
}

\section{Receipt for RECs Purchased in FY12}

\author{
CONTRACT NO. 129676 \\ Page 1 \\ BATTELLE ENERGY ALLIANCE, LLC (BEA) \\ 2525 Fremont Avenue, P. O. Box 1625, Idaho Falls, ID 83415 \\ OPERATING UNDER U.S. GOVERNMENT CONTRACT NO. DE-AC07-05ID14517
}

To: Idaho Falls Power

Effective Date: 09/18/2011

140 S Capital

Idaho Falls ID 83405

To: Bear Prairie PH: (208) 612-8429 Fax: (208) 612-8435

Completion Date: 09/19/2012

\section{STATEMENT OF WORK}

1.1. Idaho Falls Power (Subcontractor) shall furnish the following, in accordance with the requirements, terms and conditions specified or referenced in this Contract.

\begin{tabular}{|c|c|c|c|c|c|}
\hline No & 20 & 60M & Description & onitrine & Extended Pine \\
\hline 1 & 22,000 & ea & $\begin{array}{l}\text { New Western Renewable Energy Generation } \\
\text { Information System (WREGIS) Renewable Energy } \\
\text { Certificates from Wind Generation Facilities during the } \\
\text { time period June 2011 - June 2012. Subcontractor will } \\
\text { retire in the WREGIS systems the contract quantity of } \\
\text { REC's on behalf of BEA in a Retirement Sub-account } \\
\text { in accordance with the Idaho Falls Power Renewable } \\
\text { Energy Certificate Sales Agreement with an effective } \\
\text { date of June } 25,2012 \text { (Attachment A). }\end{array}$ & $\$ 1.00$ & $\$ 22,000.00$ \\
\hline
\end{tabular}

\section{RESOURCES}

2.1. The Subcontractor shall provide all resources, e.g., materials, labor, equipment, necessary to fulfill the requirements of this Contract, except as otherwise specified.

3. APPLICABLE DOCUMENTS The following documents are incorporated into, and become a part of, this Contract:

3.1. Form 540.33 , "Change Request."

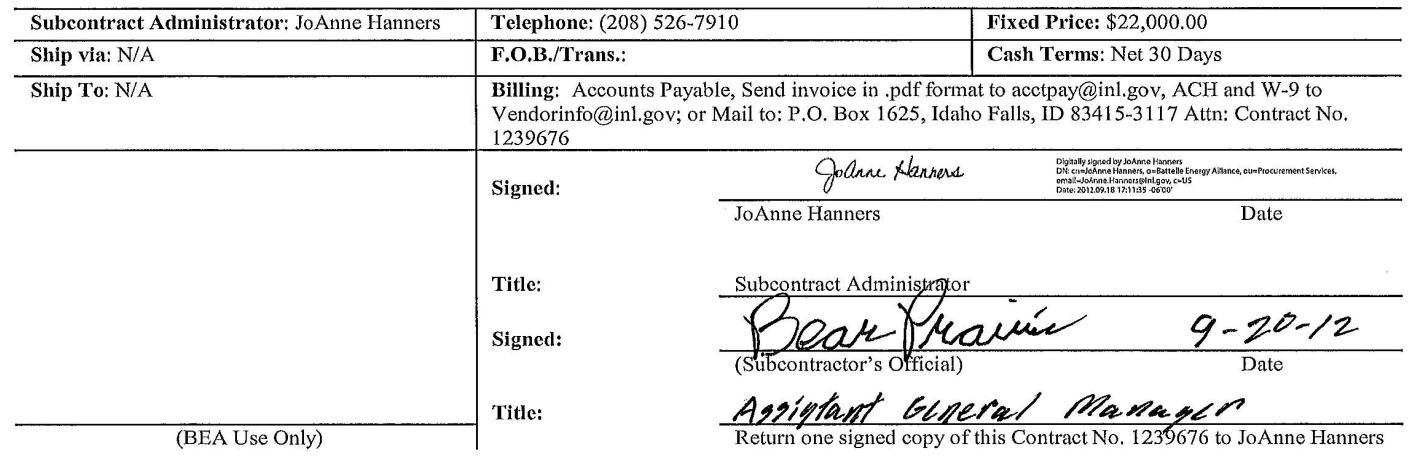




\section{TERMS AND CONDITIONS}

4.1. American Recovery and Reinvestment Act (ARRA). There is potential for work performed under this Contract to be funded by the ARRA. When such occurs, Form PROC-ARRA, General Provisions Supplement for Items/Services Acquired Under the American Recovery and Reinvestment Act, will augment other General Provisions applicable to this Contract.

4.2. General Provisions: The following document is incorporated by reference and hereby forms a part of this action: Form PROC-202, BEA General Provisions for Commercial Items/Services dated June 2011. Note: BEA's General Provisions are available at the following Internet address:

https:/inlportal.inl.gov/portal/server.pt/community/procurement/346/documents_and_fo rms.

4.3. Certification of Eligibility: Subcontractor, by entering into this Contract, certifies that it is not debarred, or proposed for debarment, by the Federal Government. Disclosure that Subcontractor was debarred, suspended, or proposed for debarment, by the Federal Government on or before the effective date of this Contract shall constitute an additional basis for termination under the Default Article of the General Provisions.

4.4. IRS Forms: Pursuant to U.S. tax law, BEA is required to report certain payments to the Internal Revenue Service (IRS). The Subcontractor agrees to furnish a completed IRS Form W-9, (for U.S. persons), W-8 (for non-U.S. persons) or other applicable IRS form to BEA prior to any request for payment. Forms can be accessed at http://www.irs.gov/app/picklist/list/formsInstructions.html. (W-9 form can be accessed at: http://www.irs.gov/pub/irs-pdf/fw9.pdf?portlet=3) Forms may be submitted electronically to: Vendorinfo@inl.gov or faxed to (208) 526-8240.

4.5. Sales Tax: BEA has been granted Direct Pay Authority for Idaho Sales Tax by the Idaho Tax Commission.

4.6. Technical Changes: Technical changes to the Contract are authorized only upon receipt and acceptance of Form 540.33, Change Request or Contract Amendment.

\section{ORDER OF PRECEDENCE}

5.1. In the event of any inconsistency between provisions of this Contract, the inconsistency shall be resolved by giving precedence as follows:

5.1.1. Contract Change documents, if any

5.1.2. Contract

5.1.3. General Provisions

5.1.4. Other provisions of this Contract, whether incorporated by reference or otherwise.

5.2. Subcontractor shall notify BEA prior to performing work based on resolution of an inconsistency by the order of precedence set forth herein.

6. PRICE

6.1. The firm-fixed price of this Contract is $\$ 22,000.00$. 


\section{DELIVERY}

Subcontractor shall complete all work and deliver the goods required by this Contract on or before 09/27/2012.

\section{ADMINISTRATION}

8.1. Subcontractor Administration: The Subcontractor's responsibilities shall be administered by Bear Prairie.

8.2. Administrative and Legal Jurisdiction. Unless the Subcontractor is otherwise notified in writing, BEA's responsibilities under this action shall be administered by JoAnne Hanners, Subcontract Administrator, or another authorized Subcontract Administrator named herein or Procurement Manager.

8.3. Technical Representative. All work performed under this Contract shall be subject to the technical direction of Ernest Fossum at (208) 526-2513.

8.4. Notices: Any notice provided for this action shall be considered as having been given: To BEA, if mailed electronically via e-mail ("JoAnne.Hanners@inl.gov") or fax, or if delivered personally to JoAnne Hanners, or if mailed by U. S. Mail addressed to JoAnne Hanners, Battelle Energy Alliance, LLC, 2525 Fremont Avenue, P. O. Box 1625, Idaho Falls, ID 83415; or to the Subcontractor, if delivered personally to its duly authorized representative at the site of work, or if mailed electronically via e-mail or fax, or by U. S. Mail addressed to the Subcontractor at 140 S. Capital, Idaho Falls, ID 83405. 
IDAHO FALLS POWER

\section{RENEWABLE ENERGY CERTIFICATE SALES AGREEMENT}

This sales agreement ("Confirmation") confirms the transaction ("Transaction") between Idaho Falls Power ("Seller") and Battelle Energy Alliance (BEA) ("Purchaser"), each individually a "Party" and together the "Parties", effective as of June 25, 2012 (the "Confirmation Effective Date").

\section{COMMERCIAL TERMS}

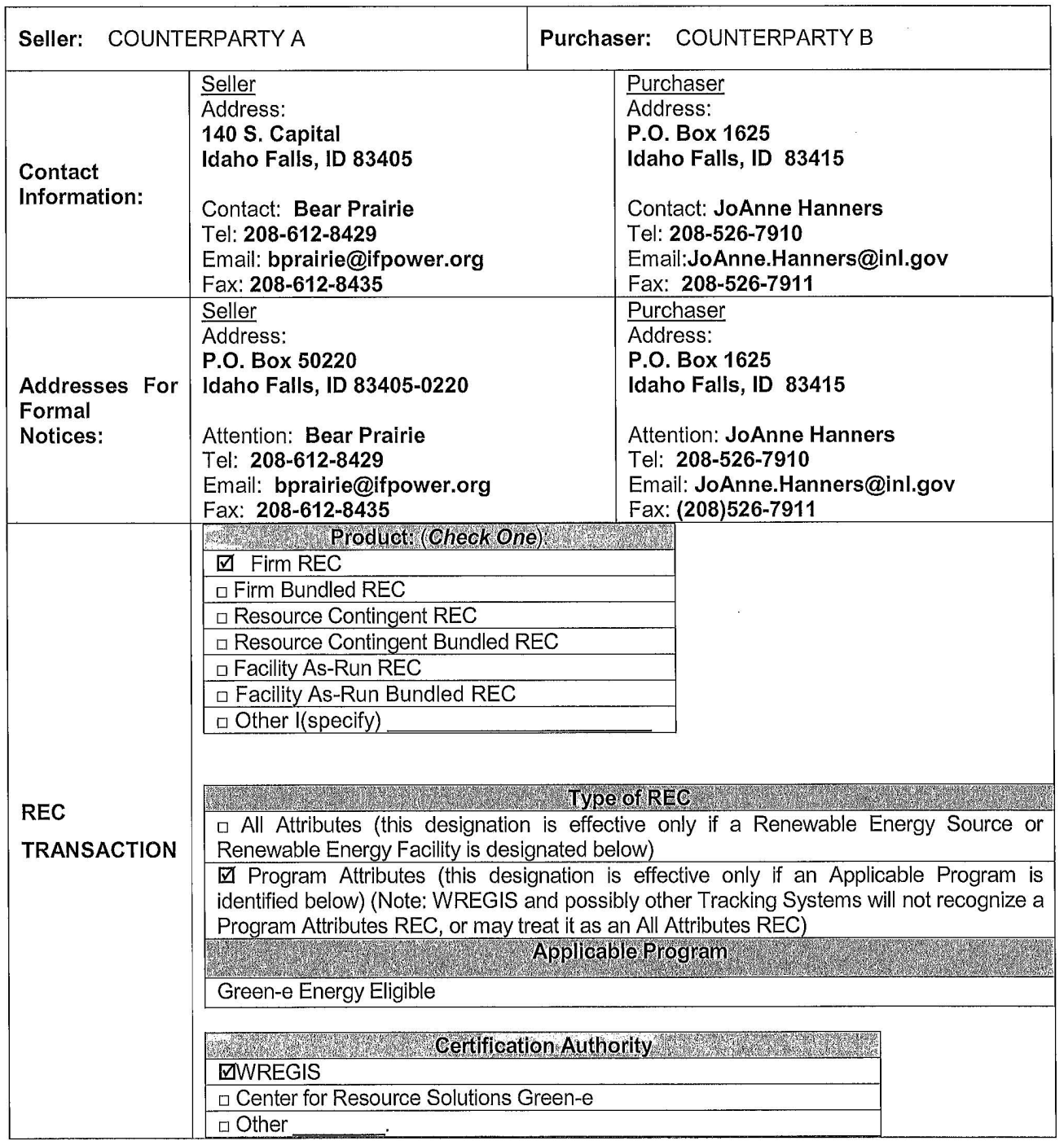




\begin{tabular}{|c|c|c|}
\hline $\begin{array}{l}\text { Contract } \\
\text { Quantity: }\end{array}$ & \multicolumn{2}{|c|}{ 22,000 WREGIS Renewable Energy Certificates } \\
\hline $\begin{array}{l}\text { Product } \\
\text { Vintage: }\end{array}$ & \multicolumn{2}{|l|}{ June 2011 - June 2012} \\
\hline $\begin{array}{l}\text { Resource } \\
\text { Type: }\end{array}$ & \multicolumn{2}{|l|}{ Wind Generation Facilities } \\
\hline Project (s) & 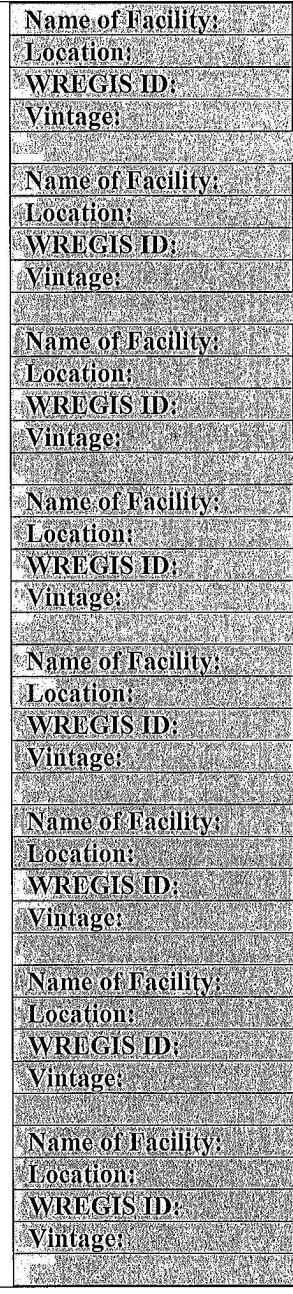 & 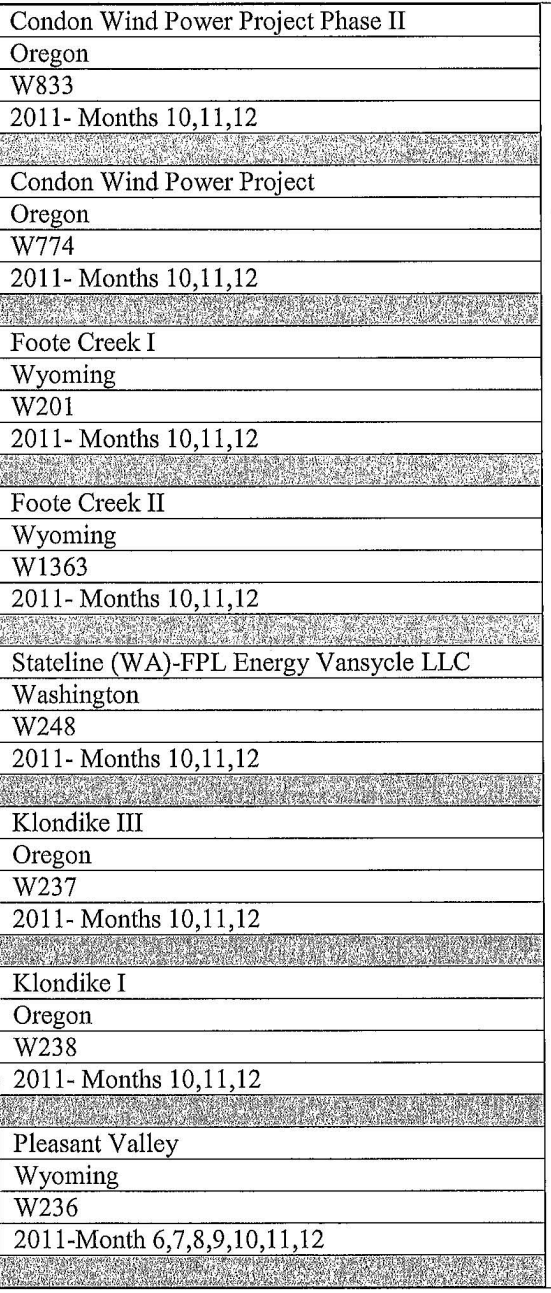 \\
\hline Contract Price: & $\$ 22,000$ Dollars & \\
\hline Delivery Term: & $\begin{array}{l}\text { Idaho Falls Power will } r \\
\text { behalf of the Purchaser }\end{array}$ & $\begin{array}{l}\text { etire in the WREGIS system the contract quan } \\
\text { in a Retirement Sub-account. }\end{array}$ \\
\hline
\end{tabular}


ATTACHMENT A TO

CONTRACT 129676

\section{SPECIAL PROVISIONS}

\subsection{Additional Definitions.}

"Environmental Attributes" means "Green Attributes". "Green Attributes" means any and all credits, benefits, emissions reductions, offsets, and allowances, howsoever entitled, attributable to the generation from the Project, and its avoided emission of pollutants. Green Attributes include but are not limited to Renewable Energy Credits, as well as: (1) any avoided emission of pollutants to the air, soil or water such as sulfur oxides (SOx), nitrogen oxides (NOx), carbon monoxide (CO) and other pollutants; (2) any avoided emissions of carbon dioxide (CO2), methane $(\mathrm{CH} 4)$, nitrous oxide, hydro fluorocarbons, per fluorocarbons, sulfur hexafluoride and other greenhouse gases (GHGs) that have been determined by the United Nations Intergovernmental Panel on Climate Change, or otherwise by law, to contribute to the actual or potential threat of altering the Earth's climate by trapping heat in the atmosphere ${ }^{1}$ (3) the reporting rights to these avoided emissions, such as Green Tag Reporting Rights. Green Tag Reporting Rights are the right of a Green Tag Purchaser to report the ownership of accumulated Green Tags in compliance with federal or state law, if applicable, and to a federal or state agency or any other party at the Green Tag Purchaser's discretion, and include without limitation those Green Tag Reporting Rights accruing under Section 1605(b) of The Energy Policy Act of 1992 and any present or future federal, state, or local law, regulation or bill, and international or foreign emissions trading program. Green Tags are accumulated on a MWh basis and one Green Tag represents the Green Attributes associated with one (1) MWh of Energy. Green Attributes do not include (i) any energy, capacity, reliability or other power attributes from the Project, (ii) production tax credits associated with the construction or operation of the Project and other financial incentives in the form of credits, reductions or allowances associated with the Project that are applicable to a state or federal income taxation obligation, (iii) fuel-related subsidies or "tipping fees" that may be paid to the Seller to accept certain fuels, or local subsidies received by the generator for the destruction of particular preexisting pollutants or the promotion of local environmental benefits, or (iv) emission reduction credits encumbered or used by the Project for compliance with local, state, or federal operating and/or air quality permits. If the Project is a biomass or biogas facility and Seller receives any tradable Green Attributes based on the greenhouse gas reduction benefits or other emission offsets attributed to its fuel usage, it shall provide Purchaser with sufficient Green Attributes to ensure that there are zero net emissions associated with the production of electricity from the Project.

"PPT" means Pacific Prevailing Time.

"Project" means the Eligible Renewable Resource(s) specified in Article One.

"WREGIS" means the Western Renewable Energy Generation Information System or its successor organization recognized under applicable laws for the registration, transfer or ownership of RECs, Environmental Attributes or Green Attributes.

"WREGIS Certificate" means "Certificate" as defined by WREGIS in the WREGIS Operating Rules. A WREGIS Certificate represents all of the renewable and environmental attributes from one MWh of electricity generation from a renewable energy Generating Unit registered with the WREGIS tracking system or a certificate imported from a Compatible Certificate Tracking System that has been converted to a WREGIS Certificate unless otherwise specified in more detail in Resource Type from table above.

"WREGIS Operating Rules" means the operating rules and requirements adopted by WREGIS.

"Retirement Sub-account" means the repository for WREGIS Certificates that the Account Holder wants to designate as retired and removed from circulation. Once a Certificate has been transferred into a

\footnotetext{
${ }^{1}$ Avoided emissions may or may not have any value for GHG compliance purposes. Although avoided emissions are included in the list of Green Attributes, this inclusion does not create any right to use those avoided emissions to comply with any GHG regulatory program.
} 
WREGIS Retirement Sub-account, it cannot be transferred again to any other account or Subaccount.

"Retirement of Certificates" means the action taken to remove a Certificate from circulation within WREGIS.

\subsection{Additional Representations and Warranties.}

(a) During the Term, each Party represents and warrants to the other that:

(i) It is an "eligible commercial entity" and an "eligible contract participant" within the meaning of United States Commodity Exchange Act $\S \S 1 \mathrm{a}(11)$ and $1 \mathrm{a}(12)$, respectively, and this Transaction has been subject to individual negotiation by the Parties;

(ii) It is duly organized, validly existing and in good standing under the law of the jurisdiction of its formation;

(iii) It shall maintain its status as a "forward contract merchant" within the meaning of the United States Bankruptcy Code (for as long as such term has the same definition as in effect as of the date of this Transaction) and

(iv) It is acting for its own account and is sophisticated, experienced and knowledgeable regarding the electricity industry and financial matters, is able to evaluate the risks and merits of the transactions contemplated herein and is not relying in any manner on the other Party for advice or analysis regarding the risks or merits of any such transaction; and

(v) Neither Party is a fiduciary of the other.

(b) Seller, and, if applicable, its successors, further represents and warrants to Purchaser throughout the Term of this Transaction that:

(i) Seller hereby provides and conveys all Green Attributes associated with all electricity generation from the Project to Buyer as part of the Product being delivered. Seller represents and warrants that Seller holds the rights to all Green Attributes from the REC's, and Seller agrees to convey and hereby conveys all such Green Attributes to Buyer as included in the delivery of the Product from the Project.

(ii) Seller has not and will not sell, pledge, assign, transfer or otherwise dispose of any of its rights and interests in and to the Green Attributes sold to Purchaser pursuant to this Transaction to any person or entity other than Purchaser, or report to any person or entity that such Green Attributes belong to any person or entity other than Purchaser;

(iii) All of the Green Attributes and energy generation from the REC's being sold to Purchaser have been sold to Purchaser and have not been sold or committed separately to any third party; Energy Resource;

(iv) The Projects qualifies and is certified by WREGIS as an Eligible Renewable

(v) The Green Attributes have not been used to meet any federal, state or local renewable energy requirement, renewable energy procurement, renewable portfolio standard, or other renewable energy mandate by Seller or, to Seller's knowledge, any third party;

(vi) Seller has and during the Term shall continue to maintain Certification from WREGIS.

\subsection{Payment and Title Transfer of RECs.}

(a) Seller's invoice shall include a charge for the REC's. Ownership of Green Attributes will be transferred through WREGIS to the Purchaser through permanent retirement in WREGIS on the Business Day following receipt of payment from Purchaser to Seller and notification to permanently retire the RECs into the Sellers designated Retirement Sub-account.

(b) Failure of Title Transfer: In the event that WREGIS fails to deliver or restricts acceptance of the Green Attributes, then each Party will provide the other Party with all documents, communications, 
and information sent to or received from WREGIS that pertain thereto. The Parties will cooperate, each at its own expense, to assure the completion of all actions and items required for transfer of the Green Attributes; and will promptly complete any and all uncompleted actions and items. If following such efforts WREGIS does not transfer the Green Attributes for reasons beyond either the Buyer's or Seller's control, Seller will provide an Attestation to Buyer and the event described hereto will not be considered an Event of Default or a failure to deliver Green Attribute

2.04 Governing Law. THIS CONFIRMATION AGREEMENT AND THE RIGHTS AND DUTIES OF THE PARTIES HEREUNDER SHALL BE GOVERNED BY AND CONSTRUED, ENFORCED AND PERFORMED IN ACCORDANCE WITH THE LAWS OF THE STATE OF IDAHO, WITHOUT REGARD TO PRINCIPLES OF CONFLICTS OF LAW. TO THE EXTENT ENFORCEABLE AT SUCH TIME, EACH PARTY WAIVES ITS RESPECTIVE RIGHT TO ANY JURY TRIAL WITH RESPECT TO ANY LITIGATION ARISING UNDER OR IN CONNECTION WITH THIS AGREEMENT.

2.05 Regulatory. The Parties intend the rates, terms and conditions of service specified in this Transaction to remain fixed throughout the Term regardless of any changes in underlying costs that would justify a change in rates under traditional cost of service principles. The Parties agree that they shall not make unilateral application to FERC for a change in rates, terms and conditions herein under Section 205 and/or 206 of The Federal Power Act nor shall either Party seek any change in the rates, terms and conditions herein based upon changes in its costs of service. Neither Party shall unilaterally seek to obtain from the FERC any relief changing the rate, charge, classification, or other term or condition of this Transaction, notwithstanding any subsequent changes in applicable law or market conditions that may occur.

\section{ACKNOWLEDGED AND AGREED TO AS OF THE CONFIRMATION EFFECTIVE DATE:}

By:

Name:

Title:
By:

Name:

Title: 
PAYMENT DUE 20 DAYS AFTER DATE OF INVOICE

Invoice for Renewable Energy Credits

Via E-Mail: joanne.hanners@inl.gov

September 20, 2012

Battelle Energy Alliance, LLC

Attn: Accounts Payable (Contract \#1239676)

PO Box 1625

Idaho Falls, ID 83415-3117

email: acctpay@inl.gov

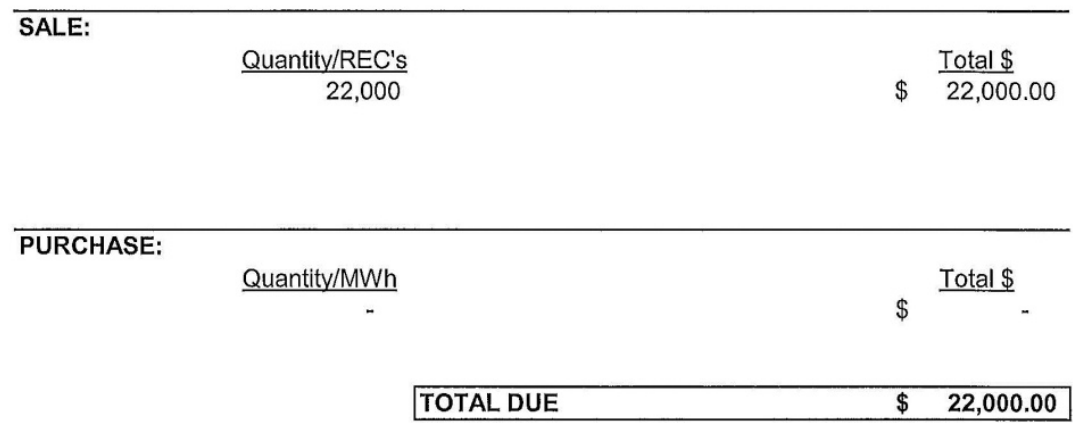

REMIT TO:

City of Idaho Falls

dba Idaho Falls Power

Controller's Office

Attn: Barb Sanderson

PO Box 50220

Idaho Falls ID 83405-0220

208.612.8230
WIRE:

Wells Fargo Bank

320 A Street

Idaho Falls ID 83405

Phone: $\quad 208.533 .6033$

Contact: Shawna Smith

Account: Clity of Idaho Falls

Account No: $\square$

ABA: 


\section{Appendix G}

\section{Scope 3 Comprehensive Tables}




\section{Appendix G}

\section{Scope 3 Comprehensive Tables}

Table G-1. Number and type of commute miles traveled by INL employees during FY08 to FY12.

\begin{tabular}{|c|c|c|c|c|c|c|c|c|c|c|}
\hline \multirow[b]{2}{*}{$\begin{array}{c}\text { Type of } \\
\text { Miles }\end{array}$} & \multicolumn{2}{|c|}{ FY08 } & \multicolumn{2}{|c|}{ FY09 } & \multicolumn{2}{|c|}{ FY10 } & \multicolumn{2}{|c|}{ FY11 } & \multicolumn{2}{|c|}{ FY12 } \\
\hline & $\begin{array}{l}\text { Number } \\
\text { of Miles }\end{array}$ & $\begin{array}{c}\mathrm{GHG} \\
\text { Emissions } \\
\left(\mathrm{MT} \mathrm{CO}_{2} \mathrm{e}\right)\end{array}$ & $\begin{array}{l}\text { Number } \\
\text { of Miles }\end{array}$ & $\begin{array}{c}\mathrm{GHG} \\
\text { Emissions } \\
\left(\mathrm{MT} \mathrm{CO}_{2} \mathrm{e}\right)\end{array}$ & $\begin{array}{c}\text { Number of } \\
\text { Miles }\end{array}$ & $\begin{array}{c}\mathrm{GHG} \\
\text { Emissions } \\
(\mathrm{MT} \\
\left.\mathrm{CO}_{2} \mathrm{e}\right)\end{array}$ & $\begin{array}{l}\text { Number of } \\
\text { Miles }\end{array}$ & $\begin{array}{c}\mathrm{GHG} \\
\text { Emissions } \\
(\mathrm{MT} \\
\left.\mathrm{CO}_{2} \mathrm{e}\right)\end{array}$ & $\begin{array}{l}\text { Number of } \\
\text { Miles }\end{array}$ & $\begin{array}{c}\mathrm{GHG} \\
\text { Emissions } \\
(\mathrm{MT} \\
\left.\mathrm{CO}_{2} \mathrm{e}\right)\end{array}$ \\
\hline $\begin{array}{l}\text { Passenger } \\
\text { Car Miles, } \\
\text { Gasoline }\end{array}$ & $\mathrm{NA}^{\mathrm{a}}$ & 0 & $14,667,892$ & 5,494 & $15,876,348$ & 5,947 & $13,148,613.94$ & 4,925 & $12,191,061.62$ & $4,566.42$ \\
\hline $\begin{array}{l}\text { Passenger } \\
\text { SUV or } \\
\text { Truck Miles, } \\
\text { Gasoline }\end{array}$ & $\mathrm{NA}^{\mathrm{a}}$ & 0 & $7,224,484$ & 3,860 & $6,472,196$ & 3,458 & $6,762,734.90$ & 3,612 & $5,790,039.03$ & $3,093.77$ \\
\hline $\begin{array}{l}\text { Motorcycle } \\
\text { Miles }\end{array}$ & $\mathrm{NA}^{\mathrm{a}}$ & 0 & $\mathrm{NA}^{\mathrm{b}}$ & 0 & 260,255 & 44 & $206,003.65$ & 35 & $141,226.58$ & 24.10 \\
\hline $\begin{array}{l}\text { Passenger } \\
\text { Car Miles, } \\
\text { Diesel }\end{array}$ & $\mathrm{NA}^{\mathrm{a}}$ & 0 & $\mathrm{NA}^{\mathrm{b}}$ & 0 & 132,135 & 74 & $397,064.15$ & 223 & $227,665.87$ & 102.92 \\
\hline $\begin{array}{l}\text { Passenger } \\
\text { SUV or } \\
\text { Truck Miles, } \\
\text { Diesel }\end{array}$ & $\mathrm{NA}^{\mathrm{a}}$ & 0 & $\mathrm{NA}^{\mathrm{b}}$ & 0 & $1,153,449$ & 648 & $1,091,658.30$ & 613 & $772,147.64$ & 433.52 \\
\hline $\begin{array}{l}\text { Passenger } \\
\text { Car Miles, } \\
\text { Alternative } \\
\text { Fuel }\end{array}$ & $\mathrm{NA}^{\mathrm{a}}$ & 0 & $\mathrm{NA}^{\mathrm{b}}$ & 0 & $\mathrm{NA}^{\mathrm{c}}$ & & $481,231.75$ & 35 & $489,078.99$ & 92.44 \\
\hline $\begin{array}{r}\text { TOTAL } \\
\text { VEHICLE } \\
\text { MILES }\end{array}$ & $20,260,127$ & 8,657 & $21,892,377$ & 9,354 & $23,894,383$ & 10,171 & $22,087,306.70$ & 9,410 & $19,611,219.73$ & $8,313.16$ \\
\hline
\end{tabular}




\begin{tabular}{|c|c|c|c|c|c|c|c|c|c|c|}
\hline \multirow[b]{2}{*}{$\begin{array}{l}\text { Type of } \\
\text { Miles }\end{array}$} & \multicolumn{2}{|c|}{ FY08 } & \multicolumn{2}{|c|}{ FY09 } & \multicolumn{2}{|c|}{ FY10 } & \multicolumn{2}{|c|}{ FY11 } & \multicolumn{2}{|c|}{ FY12 } \\
\hline & $\begin{array}{l}\text { Number } \\
\text { of Miles }\end{array}$ & $\begin{array}{c}\mathrm{GHG} \\
\text { Emissions } \\
\left(\mathrm{MT} \mathrm{CO}_{2} \mathrm{e}\right)\end{array}$ & $\begin{array}{l}\text { Number } \\
\text { of Miles }\end{array}$ & $\begin{array}{c}\mathrm{GHG} \\
\text { Emissions } \\
\left(\mathrm{MT} \mathrm{CO}_{2} \mathrm{e}\right)\end{array}$ & $\begin{array}{c}\text { Number of } \\
\text { Miles }\end{array}$ & $\begin{array}{c}\mathrm{GHG} \\
\text { Emissions } \\
(\mathrm{MT} \\
\left.\mathrm{CO}_{2} \mathrm{e}\right) \\
\end{array}$ & $\begin{array}{c}\text { Number of } \\
\text { Miles }\end{array}$ & $\begin{array}{c}\text { GHG } \\
\text { Emissions } \\
(\mathrm{MT} \\
\left.\mathrm{CO}_{2} \mathrm{e}\right) \\
\end{array}$ & $\begin{array}{c}\text { Number of } \\
\text { Miles }\end{array}$ & $\begin{array}{c}\mathrm{GHG} \\
\text { Emissions } \\
(\mathrm{MT} \\
\left.\mathrm{CO}_{2} \mathrm{e}\right)\end{array}$ \\
\hline $\begin{array}{l}\text { Walk, run or } \\
\text { bike Miles }\end{array}$ & $\mathrm{NA}^{\mathrm{a}}$ & 0 & 65,315 & 0 & 85,636 & 0 & $514,043.20$ & 0 & $84,320.40$ & 0 \\
\hline $\begin{array}{r}\text { TOTAL } \\
\text { COMMUTE } \\
\text { MILES }\end{array}$ & $20,260,127$ & 8,657 & $21,957,691$ & 9,354 & $23,980,019$ & 10,171 & $22,601,349.90$ & 9,410 & $19,695,540.14$ & $8,313.16$ \\
\hline $\begin{array}{l}\text { a. This category } \\
\text { b. This category } \\
\text { c. This was a ne }\end{array}$ & $\begin{array}{l}\text { as not consid } \\
\text { as not consid } \\
\text { category incl }\end{array}$ & $\begin{array}{l}\text { ered in the FYc } \\
\text { ered in the FY } \\
\text { uded in the FY }\end{array}$ & $\begin{array}{l}\text { commute calct } \\
\text { commute calcu } \\
\text { employee com }\end{array}$ & $\begin{array}{l}\text { ulations, which } \\
\text { ulations, which } \\
\text { nmute survey a }\end{array}$ & $\begin{array}{l}\text { nly estimated } \\
\text { ssumed empl } \\
\text { was not incl }\end{array}$ & $\begin{array}{l}\text { tal number } \\
\text { ees drove on } \\
\text { ed in the FY }\end{array}$ & $\begin{array}{l}\text { commute vehicle } \\
\text { gasoline cars and } \\
\text { commute survey }\end{array}$ & $\begin{array}{l}\text { les. } \\
\text { JVs/trucks. }\end{array}$ & & \\
\hline
\end{tabular}


Table G-2. Number of miles flown by INL employees during FY08.

\begin{tabular}{|r|c|c|}
\hline \multicolumn{1}{|c|}{ Type of Miles } & $\begin{array}{c}\text { Number of } \\
\text { Passenger-Miles }\end{array}$ & $\begin{array}{c}\text { GHG Emissions } \\
\left(\mathrm{MT} \mathrm{CO}_{2} \mathrm{e}\right)\end{array}$ \\
\hline Domestic & $18,861,146$ & 5,165 \\
\hline International & $5,558,308$ & 1,522 \\
\hline TOTAL & $24,419,454$ & 6,687 \\
\hline
\end{tabular}

Since airline miles were further broken down into short, medium, and long-haul flights, subsequent years are included in the following table:

Table G-3. Number of miles flown by INL employees during FY09 - FY12.

\begin{tabular}{|c|c|c|c|c|c|c|c|c|}
\hline \multirow[b]{2}{*}{$\begin{array}{l}\text { Type of } \\
\text { Miles }\end{array}$} & \multicolumn{2}{|c|}{ FY09 } & \multicolumn{2}{|c|}{ FY10 } & \multicolumn{2}{|c|}{ FY11 } & \multicolumn{2}{|l|}{ FY12 } \\
\hline & $\begin{array}{c}\text { Number of } \\
\text { Passenger-Miles }\end{array}$ & $\begin{array}{c}\text { GHG } \\
\text { Emissions } \\
\left(\mathrm{MT} \mathrm{CO}_{2} \mathrm{e}\right)\end{array}$ & $\begin{array}{c}\text { Number of } \\
\text { Passenger-Miles }\end{array}$ & $\begin{array}{c}\text { Number of } \\
\text { Passenger-Miles }\end{array}$ & $\begin{array}{c}\text { GHG } \\
\text { Emissions } \\
(\mathrm{MT} \\
\left.\mathrm{CO}_{2} \mathrm{e}\right) \\
\end{array}$ & \begin{tabular}{|c}
$\mathrm{GHG}$ \\
Emissions \\
$(\mathrm{MT}$ \\
$\left.\mathrm{CO}_{2} \mathrm{e}\right)$ \\
\end{tabular} & $\begin{array}{c}\text { Number of } \\
\text { Passenger-Miles }\end{array}$ & $\begin{array}{c}\mathrm{GHG} \\
\text { Emissions } \\
(\mathrm{MT} \\
\left.\mathrm{CO}_{2} \mathrm{e}\right)\end{array}$ \\
\hline Short Haul & $3,797,347$ & 1,063 & $3,302,333$ & $20,561,904$ & 3,863 & 924 & $2,231,351$ & 653 \\
\hline $\begin{array}{l}\text { Medium } \\
\text { Haul }\end{array}$ & $7,965,079$ & 1,847 & $7,631,935$ & $4,750,574$ & 1,102 & 1,770 & $3,482,410$ & 582 \\
\hline Long Haul & $23,795,526$ & 4,470 & $21,778,636$ & $2,861,280$ & 801 & 4,091 & $16,371,756$ & 3,129 \\
\hline TOTAL & $35,557,952$ & 7,380 & $32,712,904$ & $28,173,858$ & 5,765 & 6,785 & $22,085,517$ & 4,364 \\
\hline
\end{tabular}

Table G-4. Number of vehicle-miles traveled in rental cars by INL employees during FY08 - FY12.

\begin{tabular}{|c|c|c|c|c|c|c|c|c|c|c|}
\hline \multirow[b]{2}{*}{ Vehicle Class } & \multicolumn{2}{|c|}{ FY08 } & \multicolumn{2}{|c|}{ FY09 } & \multicolumn{2}{|c|}{ FY10 } & \multicolumn{2}{|c|}{ FY11 } & \multicolumn{2}{|c|}{ FY12 } \\
\hline & $\begin{array}{c}\text { Number of } \\
\text { Vehicle } \\
\text { Miles }\end{array}$ & $\begin{array}{c}\mathrm{GHG} \\
\text { Emissions } \\
(\mathrm{MT} \\
\left.\mathrm{CO}_{2} \mathrm{e}\right)\end{array}$ & $\begin{array}{c}\text { Number } \\
\text { of } \\
\text { Vehicle } \\
\text { Miles }\end{array}$ & $\begin{array}{c}\mathrm{GHG} \\
\text { Emissions } \\
(\mathrm{MT} \\
\left.\mathrm{CO}_{2} \mathrm{e}\right) \\
\end{array}$ & $\begin{array}{c}\text { Number } \\
\text { of } \\
\text { Vehicle } \\
\text { Miles }\end{array}$ & $\begin{array}{c}\mathrm{GHG} \\
\text { Emissions } \\
(\mathrm{MT} \\
\left.\mathrm{CO}_{2} \mathrm{e}\right)\end{array}$ & $\begin{array}{c}\text { Number } \\
\text { of } \\
\text { Vehicle } \\
\text { Miles }\end{array}$ & $\begin{array}{c}\text { GHG } \\
\text { Emissions } \\
(\mathrm{MT} \\
\left.\mathrm{CO}_{2} \mathrm{e}\right)\end{array}$ & $\begin{array}{c}\text { Number } \\
\text { of } \\
\text { Vehicle } \\
\text { Miles }\end{array}$ & $\begin{array}{c}\mathrm{GHG} \\
\text { Emissions } \\
(\mathrm{MT} \\
\left.\mathrm{CO}_{2} \mathrm{e}\right)\end{array}$ \\
\hline Passenger Cars & 499,500 & 187 & 533,177 & 200 & 490,076 & 183 & 632,548 & 237 & 478,904 & 179 \\
\hline $\begin{array}{l}\text { Light-Duty } \\
\text { Truck/Van/SUV }\end{array}$ & 306,413 & 164 & 257,392 & 138 & 254,027 & 136 & 292,809 & 156 & 225,320 & 120 \\
\hline TOTAL & 805,913 & 351 & 790,569 & 338 & 744,103 & 319 & 925,357 & 393 & 704,225 & 300 \\
\hline
\end{tabular}




\section{Appendix $\mathrm{H}$}

\section{Calculation Spreadsheets \& Notes}




\section{Appendix $\mathrm{H}$}

\section{Calculation Spreadsheets \& Notes}

Table H-1 summarizes the following for each of INL's emissions categories considered during FY12:

- $\quad$ Source spreadsheets for data calculation (e.g., calculating how much waste INL produced based on quantities from each facility)

- Source spreadsheets for GHG calculation (e.g., calculating how many GHGs were produced by INL's annual waste disposal)

- Applicable comments (the TSD equation number[s] used, who provided the data, etc.).

Table H-1. Calculation Spreadsheets and Comments for Emissions Categories included in the INL FY12 GHG Inventory.

\begin{tabular}{|c|c|c|c|c|}
\hline Scope & $\begin{array}{l}\text { Emissions } \\
\text { Category }\end{array}$ & $\begin{array}{l}\text { FY12 Spreadsheet for Data } \\
\text { Calculation }\end{array}$ & $\begin{array}{l}\text { FY12 Spreadsheet } \\
\text { for GHG Calculation }\end{array}$ & Comments \\
\hline All & Summary & $\begin{array}{l}\text { Sheet: "Sheet1," "Overall } \\
\text { Summary Stats } \\
\text { 16Jan13.xlsx" }\end{array}$ & $\begin{array}{l}\text { Sheet: "Sheet1" and } \\
\text { "Summary for } \\
\text { Plots," "Overall } \\
\text { Summary Stats } \\
\text { 16Jan13.xlsx" }\end{array}$ & None. \\
\hline \multirow[t]{3}{*}{1} & $\begin{array}{l}\text { Stationary } \\
\text { Combustion }\end{array}$ & $\begin{array}{l}\text { Sheet: "Fuel Data," "FY12 } \\
\text { Summary for GHG - } \\
\text { Stationary Combustion } \\
\text { 21Jan13.xlsx" }\end{array}$ & $\begin{array}{l}\text { Sheet: "GHG } \\
\text { Emissions," "FY12 } \\
\text { Summary for GHG - } \\
\text { Stationary } \\
\text { Combustion } \\
\text { 21Jan13.xlsx" }\end{array}$ & $\begin{array}{l}\text { Default Methodology, } \\
\text { Equations A-1, A-2, and } \\
\text { A-3. } \\
\text { Fuel data provided by } \\
\text { Ernest Fossum and } \\
\text { Jacqueline Dedic (INL } \\
\text { Energy Management). }\end{array}$ \\
\hline & $\begin{array}{l}\text { Mobile } \\
\text { Combustion }\end{array}$ & $\begin{array}{l}\text { Sheet: "Report (Sorted)," } \\
\text { "FY12 Summary for GHG - } \\
\text { Mobile Combustion } \\
\text { 22Jan13.xlsx" }\end{array}$ & $\begin{array}{l}\text { Sheet: "GHG } \\
\text { Emissions," "FY12 } \\
\text { Summary for GHG - } \\
\text { Mobile Combustion } \\
\text { 22Jan13.xlsx" }\end{array}$ & $\begin{array}{l}\text { Advanced Methodology, } \\
\text { Equations A-5, A-9, and } \\
\text { A-10 (A-11 and A-12 for } \\
\text { biogenic). } \\
\text { Fuel data extracted from } \\
\text { INL TIMS database - } \\
\text { GHG Summary Revised } \\
\text { Report by Kim Frerichs } \\
\text { (INL Pollution } \\
\text { Prevention). }\end{array}$ \\
\hline & $\begin{array}{l}\text { Fugitive } \\
\text { Emissions: } \\
\text { Refrigerants }\end{array}$ & $\begin{array}{l}\text { Sheet: "Emissions Summary } \\
\text { Sheet,", "GHG Report FY12 } \\
\text { Backup Summary Sheets - } \\
\text { 16Jan13.xlsx" }\end{array}$ & $\begin{array}{l}\text { Sheet: "Emissions } \\
\text { Summary Sheet,", } \\
\text { "GHG Report FY12 } \\
\text { Backup Summary } \\
\text { Sheets - } \\
\text { 16Jan13.xlsx" }\end{array}$ & $\begin{array}{l}\text { Advanced Methodology, } \\
\text { Equation A-15. } \\
\text { Data compiled by Kim } \\
\text { Frerichs (INL Pollution } \\
\text { Prevention). }\end{array}$ \\
\hline
\end{tabular}


Table H-1. (continued).

\begin{tabular}{|c|c|c|c|c|}
\hline Scope & $\begin{array}{l}\text { Emissions } \\
\text { Category }\end{array}$ & $\begin{array}{l}\text { FY12 Spreadsheet for Data } \\
\text { Calculation }\end{array}$ & $\begin{array}{l}\text { FY12 Spreadsheet } \\
\text { for GHG Calculation }\end{array}$ & Comments \\
\hline & $\begin{array}{l}\text { Fugitive } \\
\text { Emissions: } \\
\text { Onsite } \\
\text { Landfill }\end{array}$ & $\begin{array}{l}\text { Sheet: "LandfillData," } \\
\text { "Landfill Report for } \\
\text { LandGEM 18Oct12.xlsx" }\end{array}$ & $\begin{array}{l}\text { Sheet: "FY12 GHG } \\
\text { Calcs," "Landfill } \\
\text { Report for } \\
\text { LandGEM } \\
\text { 18Oct12.xlsx" }\end{array}$ & $\begin{array}{l}\text { Used LandGEM and } \\
\text { Equation A-34 from TSD. } \\
\text { Data pulled from } \\
\text { INWMIS by Kim } \\
\text { Frerichs (INL Pollution } \\
\text { Prevention). }\end{array}$ \\
\hline & $\begin{array}{l}\text { Fugitive } \\
\text { Emissions: } \\
\text { Onsite } \\
\text { Wastewater } \\
\text { Treatment }\end{array}$ & $\begin{array}{l}\text { Sheet: "Wastewater Types," } \\
\text { "FY12 Wastewater for GHG } \\
\text { (Scope 1+3) 9Oct12.xlsx" }\end{array}$ & $\begin{array}{l}\text { Sheet: "Onsite } \\
\text { Wastewater," "FY12 } \\
\text { Wastewater for } \\
\text { GHG (Scope 1+3) } \\
\text { 9Oct12.xlsx" }\end{array}$ & $\begin{array}{l}\text { Default Methodology, } \\
\text { Equations A-23 and A-24 } \\
\text { from TSD. } \\
\text { Employee counts } \\
\text { provided by Julie } \\
\text { Chappell (INL Human } \\
\text { Resources). }\end{array}$ \\
\hline \multirow[t]{3}{*}{2} & $\begin{array}{l}\text { Purchased } \\
\text { Electricity }\end{array}$ & $\begin{array}{l}\text { Sheet: "Elec Totals," "FY12 } \\
\text { Summary for GHG - Scope } 2 \\
\text { 21Jan13.xlsx" }\end{array}$ & $\begin{array}{l}\text { Sheet: "GHGCalcs," } \\
\text { "FY12 Summary for } \\
\text { GHG - Scope } 2 \\
\text { 21Jan13.xlsx" }\end{array}$ & $\begin{array}{l}\text { Default Methodology, } \\
\text { Equations B-1 and B-2 } \\
\text { from TSD. } \\
\text { Data provided by Ernest } \\
\text { Fossum and Jacqueline } \\
\text { Dedic (INL Energy } \\
\text { Management). }\end{array}$ \\
\hline & $\begin{array}{l}\text { Transmission } \\
\& \\
\text { Distribution } \\
\text { Losses } \\
\text { (Owned) }\end{array}$ & $\begin{array}{l}\text { Sheet: "GHGCalcs," "FY12 } \\
\text { Summary for GHG - Scope } 2 \\
\text { 21Jan13.xlsx" }\end{array}$ & $\begin{array}{l}\text { Sheet: "GHGCalcs," } \\
\text { "FY12 Summary for } \\
\text { GHG - Scope } 2 \\
\text { 21Jan13.xlsx" }\end{array}$ & $\begin{array}{l}\text { Default Methodology, } \\
\text { Equations B-1 and B-2 } \\
\text { from TSD. } \\
\text { T\&D loss information } \\
\text { provided by Ernest } \\
\text { Fossum (INL Energy } \\
\text { Management). }\end{array}$ \\
\hline & $\begin{array}{l}\text { Purchased } \\
\text { RECs }\end{array}$ & $\begin{array}{l}\text { "FY2012 REC Purchase } \\
\text { Documents 9-24-12.pdf" }\end{array}$ & $\begin{array}{l}\text { Sheet: "GHGCalcs," } \\
\text { "FY12 Summary for } \\
\text { GHG - Scope } 2 \\
\text { 21Jan13.xlsx" }\end{array}$ & $\begin{array}{l}\text { Default Methodology, } \\
\text { Equations B-28 and B-29 } \\
\text { from TSD. } \\
\text { RECs Receipts provided } \\
\text { by Ernest Fossum (INL } \\
\text { Energy Management). }\end{array}$ \\
\hline \multirow[t]{2}{*}{3} & $\begin{array}{l}\text { Transmission } \\
\& \\
\text { Distribution } \\
\text { Losses } \\
\text { (Shared) }\end{array}$ & $\begin{array}{l}\text { Sheet: "GHGCalcs," "FY12 } \\
\text { Summary for GHG - Scope } 2 \\
\text { 21Jan13.xlsx" }\end{array}$ & $\begin{array}{l}\text { Sheet: "GHGCalcs," } \\
\text { "FY12 Summary for } \\
\text { GHG - Scope } 2 \\
\text { 21Jan13.xlsx" }\end{array}$ & $\begin{array}{l}\text { Default Methodology, } \\
\text { Equations C-3, C-4, and } \\
\text { C-5 from TSD. }\end{array}$ \\
\hline & $\begin{array}{l}\text { Employee } \\
\text { Commuting }\end{array}$ & $\begin{array}{l}\text { Sheet: "BEA Totals," "FY12 } \\
\text { Commuter Survey BEA and } \\
\text { DOE Results.xlsx" }\end{array}$ & $\begin{array}{l}\text { Sheet: "GHGs," } \\
\text { "FY12 Commuter } \\
\text { Survey BEA and } \\
\text { DOE Results.xlsx" }\end{array}$ & $\begin{array}{l}\text { Default Methodology, } \\
\text { Equations C-14, C-15, } \\
\text { and C-16 from TSD. } \\
\text { FY12 Employee data } \\
\text { provided by Julie } \\
\text { Chappell (INL Human } \\
\text { Resources). }\end{array}$ \\
\hline
\end{tabular}


Table H-1. (continued).

\begin{tabular}{|c|c|c|c|c|}
\hline Scope & $\begin{array}{l}\text { Emissions } \\
\text { Category }\end{array}$ & $\begin{array}{c}\text { FY12 Spreadsheet for Data } \\
\text { Calculation }\end{array}$ & $\begin{array}{l}\text { FY12 Spreadsheet } \\
\text { for GHG Calculation }\end{array}$ & Comments \\
\hline & $\begin{array}{l}\text { Business Air } \\
\text { Travel }\end{array}$ & $\begin{array}{l}\text { Sheet: "Sheet1," } \\
\text { "INL-Miles-1001-0930.xlsx" }\end{array}$ & $\begin{array}{l}\text { Sheet: "8.1 Air } \\
\text { Travel," "FY } 2013 \\
\text { CEDR 08132012 } \\
\text { INL - BEA - KIF } \\
\text { 8Oct12.xlsx" }\end{array}$ & $\begin{array}{l}\text { Default Methodology, } \\
\text { Equations C-1 and C-2 } \\
\text { from TSD. } \\
\text { Data provided by TMP } \\
\text { Travel on behalf of Dick } \\
\text { Schuman (INL Travel } \\
\text { Office). }\end{array}$ \\
\hline & $\begin{array}{l}\text { Business } \\
\text { Ground } \\
\text { Travel: } \\
\text { Rental } \\
\text { Vehicle }\end{array}$ & $\begin{array}{l}\text { Sheet: "Avis-all," "FY12 } \\
\text { Rental Car Miles Summary } \\
\text { 8Oct12.xls" }\end{array}$ & $\begin{array}{l}\text { Sheet: "GHGs," } \\
\text { "FY12 Rental Car } \\
\text { Miles Summary } \\
\text { 8Oct12.xlsx" }\end{array}$ & $\begin{array}{l}\text { Advanced } \\
\text { Methodology 2, } \\
\text { Equations C-11, C-12, } \\
\text { and C-13 from TSD. } \\
\text { Data provided by travel } \\
\text { vendor on behalf of Dick } \\
\text { Schuman (INL Travel } \\
\text { Office). }\end{array}$ \\
\hline & $\begin{array}{l}\text { Business } \\
\text { Ground } \\
\text { Travel: } \\
\text { Personal } \\
\text { Vehicle }\end{array}$ & $\begin{array}{l}\text { Sheet: "POV Totals," "2012 } \\
\text { POV Miles - ER.xlsx"” }\end{array}$ & $\begin{array}{l}\text { Sheet: "GHGs," } \\
\text { "2012 POV Miles - } \\
\text { ER.xlsx" }\end{array}$ & $\begin{array}{l}\text { Advanced } \\
\text { Methodology 2, } \\
\text { Equations C-11, C-12, } \\
\text { and C-13 from TSD. } \\
\text { Data pulled from INL } \\
\text { Expense Reports - } \\
\text { provided by Dick } \\
\text { Schuman (INL). }\end{array}$ \\
\hline & $\begin{array}{l}\text { Contracted } \\
\text { MSW } \\
\text { Disposal }\end{array}$ & $\begin{array}{l}\text { Sheets: "FY12 sml," "FY12 } \\
\text { 30yd," and "Summary," } \\
\text { "Sanitation Department } \\
\text { Report FY12.xls" }\end{array}$ & $\begin{array}{l}\text { Sheet: "Offsite } \\
\text { MSW," "FY12 } \\
\text { Offsite MSW for } \\
\text { GHG - } \\
\text { 18Oct12.xlsx" }\end{array}$ & $\begin{array}{l}\text { Default Methodology, } \\
\text { Equation C-6 from TSD } \\
\text { (C-7 for biogenic). } \\
\text { Data compiled by Kim } \\
\text { Frerichs (INL Pollution } \\
\text { Prevention). }\end{array}$ \\
\hline & $\begin{array}{l}\text { Contracted } \\
\text { Wastewater } \\
\text { Treatment }\end{array}$ & $\begin{array}{l}\text { Sheet: "Wastewater Types," } \\
\text { "FY12 Wastewater for GHG } \\
\text { (Scope 1+3) 9Oct12.xlsx" }\end{array}$ & $\begin{array}{l}\text { Sheet: "Offsite } \\
\text { Wastewater," "FY12 } \\
\text { Wastewater for } \\
\text { GHG (Scope 1+3) } \\
\text { 9Oct12.xlsx" }\end{array}$ & $\begin{array}{l}\text { Default Methodology, } \\
\text { Used Equations A-19, } \\
\text { A-20, and A-22 from } \\
\text { TSD. } \\
\text { Employee counts } \\
\text { provided by Julie } \\
\text { Chappell (INL Human } \\
\text { Resources). }\end{array}$ \\
\hline
\end{tabular}

